DOE/D/12584-272

GJPO-MWTP-31

Grand Junction Projects Office Mixed-Waste Treatment Program

\title{
PO*WW*ER Mobile Treatment Unit Process Hazards Analysis
}

June 1996

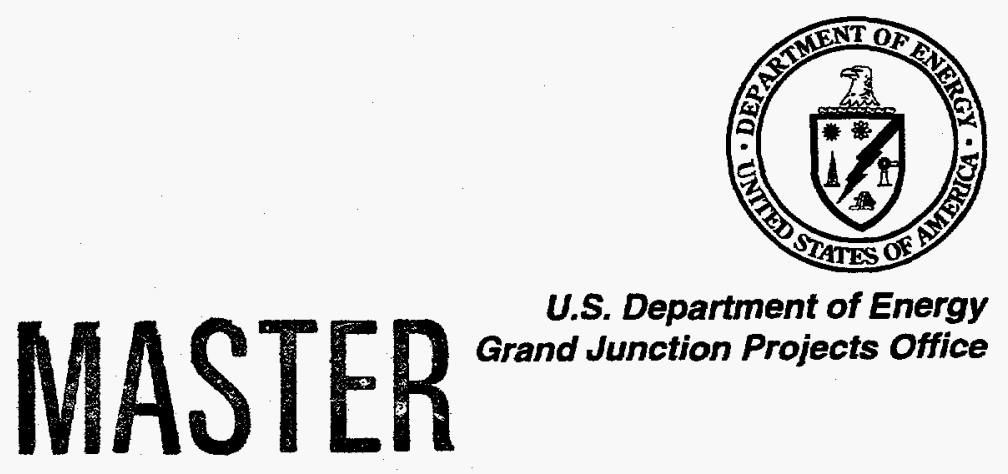

Approved for public release; distribution is unlimited.

$\bullet \diamond$ ol Work Performed Under DOE Contract No. DE-AC04-94AL96907 for the U.S. Department of Energy DISTRIBUTION OF TitS DOCUMENT is inummed 
This report was prepared as an account of work sponsored by an agency of the United States Government. Neither the United States Government nor any agency thereof, nor any of their employees, makes any warranty, express or implied, or assumes any legal liability or responsibility for the accuracy, completeness, or usefulness of any information, apparatus, product, or process disclosed in this report, or represents that its use would not infringe privately owned rights. Reference herein to any specific commercial product, process, or service by trade name, trademark, manufacturer, or otherwise, does not necessarily constitute or imply its endorsement, recommendation, or favoring by the United States Government or any agency thereof. The views and opinions of authors expressed herein do not necessarily state or reflect those of the United States Government or any agency thereof. 


\section{DISCLAIMER}

This report was prepared as an account of work sponsored by an agency of the United States Government. Neither the United States. Government nor any agency thereof, nor any of their employees, makes any warranty, express or implied, or assumes any legal liability or responsibility for the accuracy, completeness, or usefulness of any information, apparatus, product, or process disclosed, or represents that its use would not infringe privately owned rights. Reference herein to any specific commercial product, process, or service by trade name, trademark, manufacturer, or otherwise does not necessarily constitute or imply its endorsement, recommendation, or favoring by the United States Government or any agency thereof. The views and opinions of authors expressed herein do not necessarily state or reflect those of the United States Government or any agency thereof. 
DISCLAMMER

Portions of this document may be illegible in electronic image products. Images are produced from the best available original document. 


\title{
PO*WW*ER Mobile Treatment Unit Process Hazards Analysis
}

June 1996

Prepared for

U.S. Department of Energy

Albuquerque Operations Office

Grand Junction Projects Office

\author{
Prepared by \\ Rust Geotech \\ Grand Junction, Colorado
}

Engineering Project Number ENG-430-0003-06-000

Engineering Document Number E0370600

Work Performed Under DOE Contract No. DE-AC04-94AL96907 
This page intentionally blank 


\section{Signature Page}

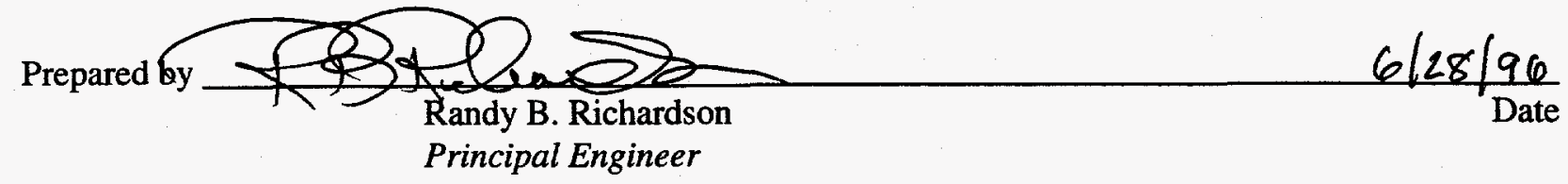

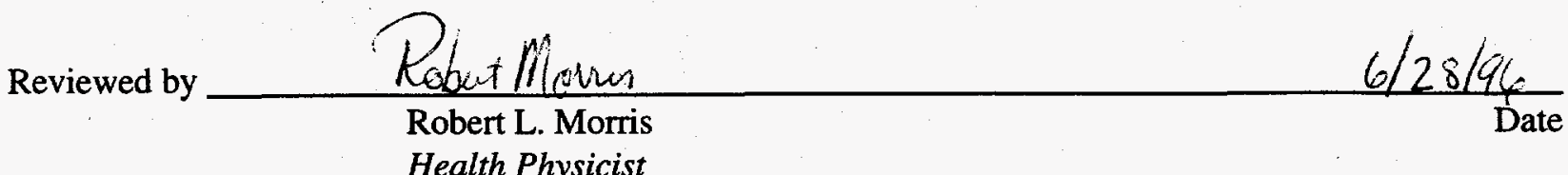

Safety Assessment Approved by

Quality Assurance Manager 
This page intentionally blank 


\section{Contents}

Page

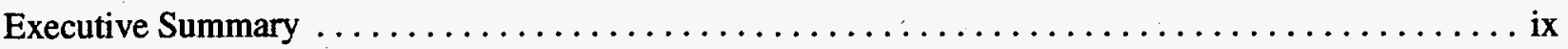

Abbreviations, Acronyms, and Initialisms $\ldots \ldots \ldots \ldots \ldots \ldots \ldots \ldots \ldots \ldots \ldots \ldots \ldots \ldots \ldots \ldots$

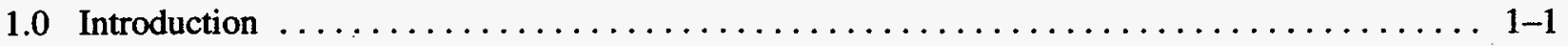

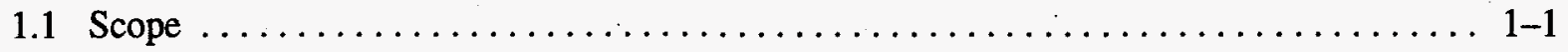

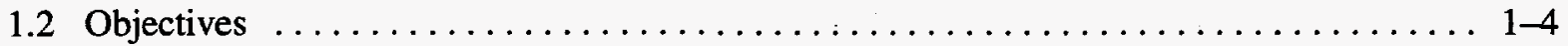

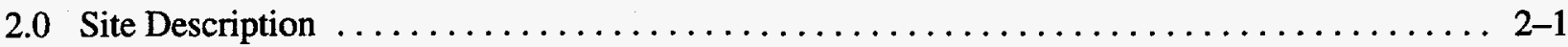

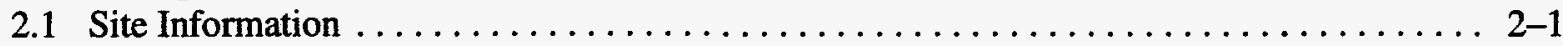

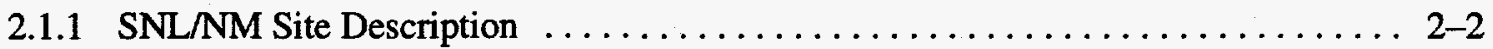

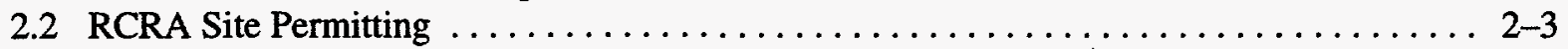

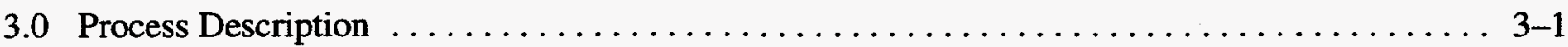

3.1 PO*WW*ER Mixed-Waste Treatment Process $\ldots \ldots \ldots \ldots \ldots \ldots \ldots \ldots \ldots \ldots \ldots \ldots \ldots$

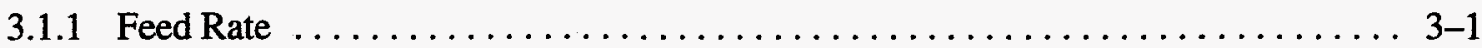

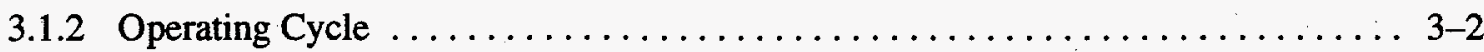

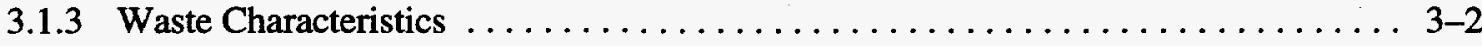

3.2 Treatment of Radioactive Waste By-Products . . . . . . . . . . . . . . . . 3-2

3.3 Decontamination and Decommissioning Prior to Shipment to Next Host Site . . . . . . 3-3

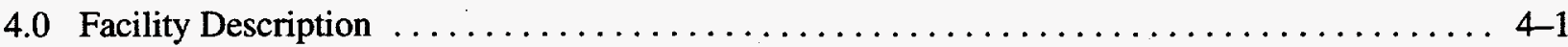

4.1 Mixed Waste Treatment Skids ........................

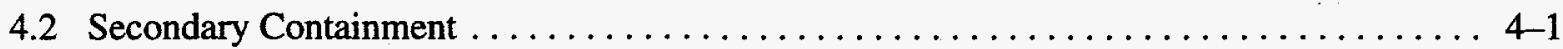

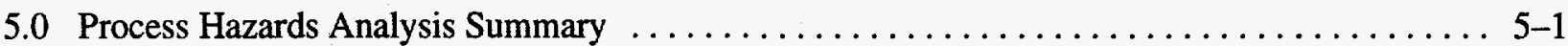

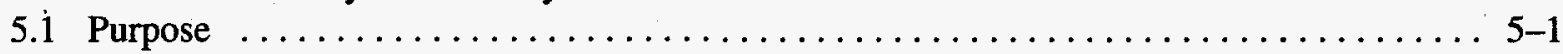

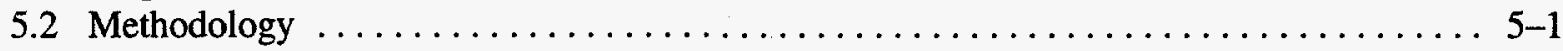

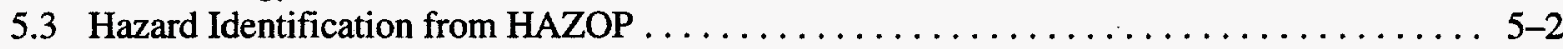

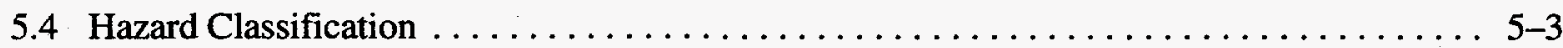

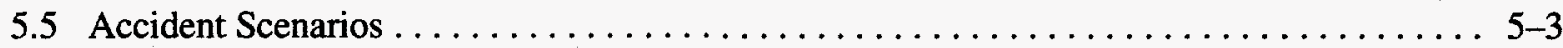

5.5.1 Design Basis Accident for the PO*WW*ER MTU $\ldots \ldots \ldots \ldots \ldots \ldots \ldots \ldots$. $\ldots \ldots$

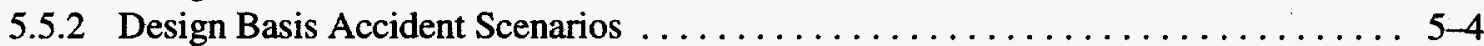

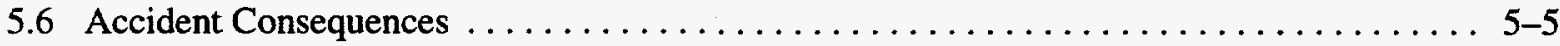

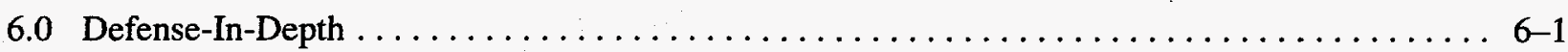

7.0 Conclusions and Recommendations $\ldots \ldots \ldots \ldots \ldots \ldots \ldots \ldots \ldots \ldots \ldots \ldots \ldots \ldots \ldots$

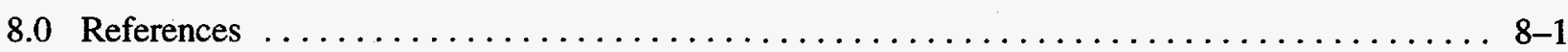




\section{Appendices}

Appendix A. Evaluation Basis Site Characteristics $\ldots \ldots \ldots \ldots \ldots \ldots \ldots \ldots \ldots \ldots \ldots \ldots \ldots \ldots \ldots$

A.1 Assumed Generic Site Characteristics . ...................... A-1

A.2 Assumed Attributes of Generic Secondary Containment ................ A-1

A.3 MTU Accidents as Initiators of External Accidents $\ldots \ldots \ldots \ldots \ldots \ldots \ldots \ldots \ldots$ A-2

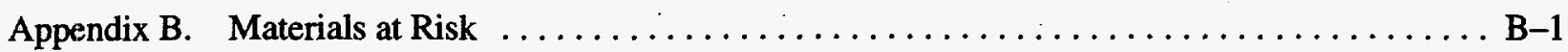

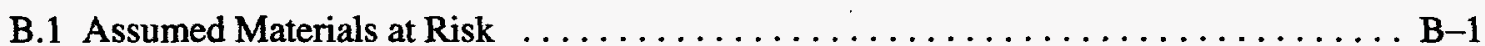

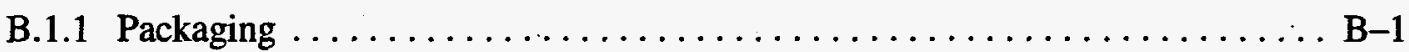

B.1.2 Content Characteristics (waste acceptance criteria) $\ldots \ldots \ldots \ldots \ldots \ldots$ B-1

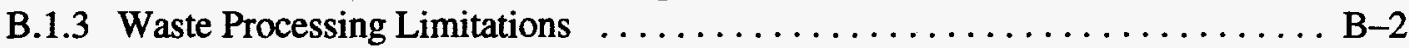

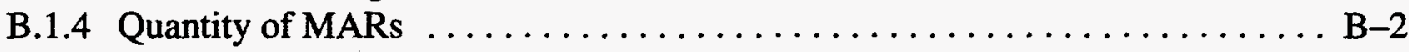

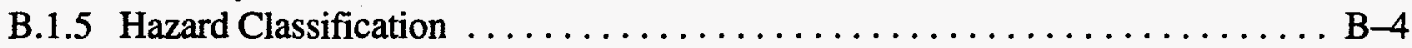

B.2 Evaluation Basis Waste Characteristics $\ldots \ldots \ldots \ldots \ldots \ldots \ldots \ldots \ldots \ldots \ldots \ldots \ldots$ B-7

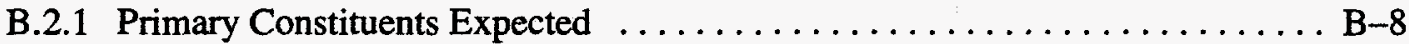

B.2.2 Concentrations of Major Hazardous Constituents $\ldots \ldots \ldots \ldots \ldots \ldots \ldots$ B-8

B.2.3 Radioactive Contaminants . . . . . . . . . . . . . . . .

B.3 Assumed Cases for Process Hazards Analysis $\ldots \ldots \ldots \ldots \ldots \ldots \ldots \ldots \ldots \ldots$ B-9

B.3.1 Worst Case . . . . . . . . . . . . . . . . . . . . . . . . B-9

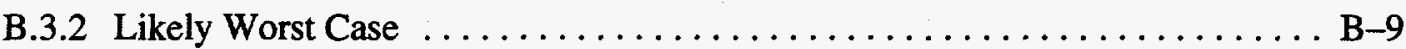

B.3.3 Likely Low-Activity and Low-Hazardous Concentrations . . . . . . . . . B-10

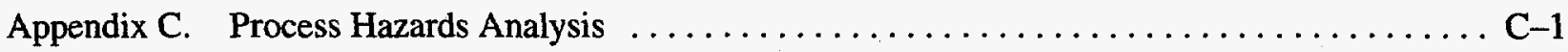

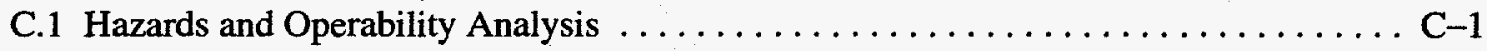

C.2 HAZOP Analysis Action Item Tracking and Risk Reduction $\ldots \ldots \ldots \ldots \ldots \ldots$ C-51

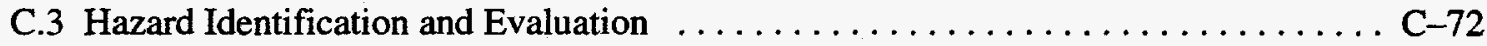

C.4 Design Basis Accident Analysis Scenarios for Selected Accidents (Fault Trees) . . . C-75

C.5 Unmitigated Accident Consequences $\ldots \ldots \ldots \ldots \ldots \ldots \ldots \ldots \ldots \ldots \ldots \ldots \ldots$

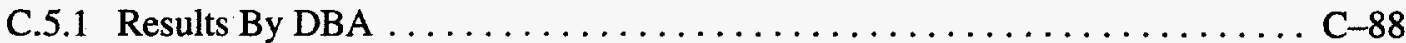

C.5.2 Source-Term Analysis $\ldots \ldots \ldots \ldots \ldots \ldots \ldots \ldots \ldots \ldots \ldots \ldots \ldots$ C -88

C.5.3 Description of Calculational Methods $\ldots \ldots \ldots \ldots \ldots \ldots \ldots \ldots$ C -89

\section{Tables}

Table 5-1. Radiological Dose and Hazardous Concentrations for the Fire DBA $\ldots \ldots \ldots$

A.1-1. Evaluation Basis Site Characteristics Summary (EBSC) $\ldots \ldots \ldots \ldots \ldots \ldots \ldots$ A-1

B.1.4-1. Summary of Volume and Weight of Materials at Risk $\ldots \ldots \ldots \ldots \ldots \ldots \ldots$ B-4

B.1.5-2. Reportable Quantities for Hazardous Substances from 40 CFR $302 \ldots \ldots \ldots \ldots$. . . .

B.2.1-1. Summary of Hazardous Waste Properties $\ldots \ldots \ldots \ldots \ldots \ldots \ldots \ldots \ldots$ B-8

B.2.2-1. Evaluation Basis Waste Characteristics $\ldots \ldots \ldots \ldots \ldots \ldots \ldots \ldots \ldots \ldots \ldots \ldots$ B-9

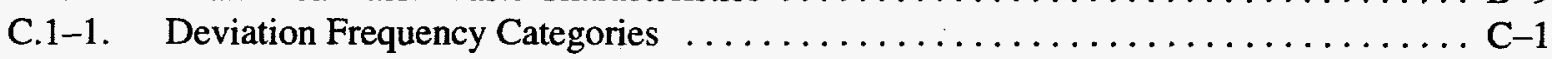

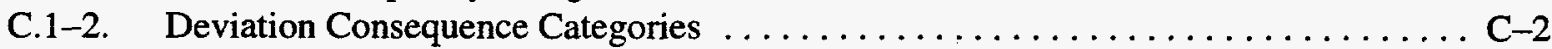

C.2-1. Mitigation of HAZOP Analysis Action Items $\ldots \ldots \ldots \ldots \ldots \ldots \ldots \ldots \ldots \ldots \ldots$

C.3-1. Accident Initiating Event Binning $\ldots \ldots \ldots \ldots \ldots \ldots \ldots \ldots \ldots \ldots \ldots \ldots \ldots \ldots \ldots \ldots$

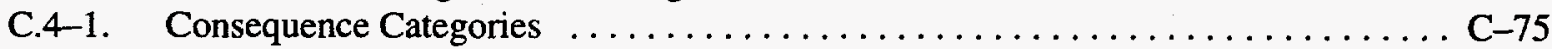

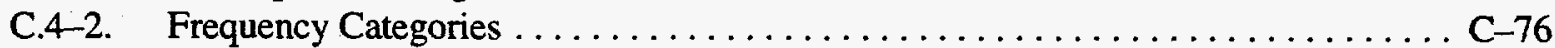

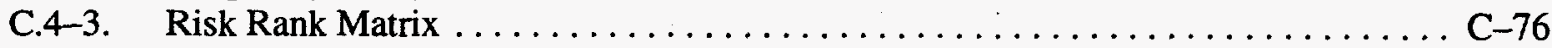




\section{Tables (continued)}

Page

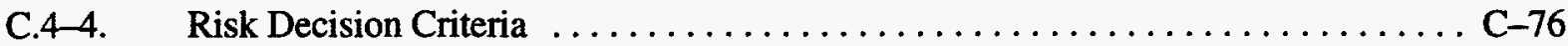

C.5.3-1. Unmitigated Consequences for the PO*WW*ER Unit Fire DBAs . . . . . . . . C-91

C.5.3-2. Unmitigated Accident Consequences for "Worst Case" Source-Term Scenario . . . . C-92

C.5.3-3. Unmitigated Accident Consequences for "Likely Worst Case"

Source-Term Scenario . . . . . . . . . . . . . . . . . . . . . . . . C-92

C.5.3-4. Unmitigated Accident Consequences for "Likely Low-Hazard Case"

Source-Term Scenario . . . . . . . . . . . . . . . . . . . . . . . C-93

C.5.3-5. Input Parameter Values Used in The Unmitigated Accident Analyses . . . . . . C-93

\section{Figures}

Figure 1-1. Evaporative Oxidation Process Flow Diagram $\ldots \ldots \ldots \ldots \ldots \ldots \ldots \ldots \ldots \ldots$ 1-2

2-1. SNL/NM - RMWMF Location Map of Proposed PO*WW*ER MTU . . . . . . . 2-4

2-2. Sandia National Laboratories/New Mexico-Location Map . . . . . . . . . . . 2-5

4-1. PO*WW*ER MTU Plan View and Segmentation for Hazard Classification . . . . . 4-3

B.1.5-1 Hazard Classification Process $\ldots \ldots \ldots \ldots \ldots \ldots \ldots \ldots \ldots \ldots \ldots \ldots \ldots \ldots \ldots \ldots$

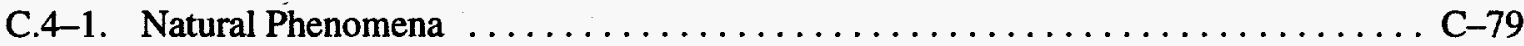

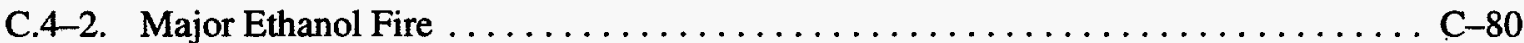

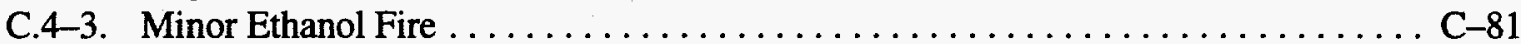

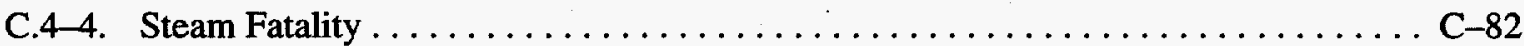

C.4-5. Chronic Steam Release ............................. C-83

C.4-6. Personal Injury from Exposure from Sulfuric Acid Loss of Containment . . . . . . . C-85

C.4-7. Personal Injury from Exposure from Sodium Hydroxide Loss of Containment . . . C-86

C.4-8. Personal Injury from Chemical Loss of Containment and Reaction . . . . . . C -87 
This page intentionally blank 


\section{Executive Summary}

In response to the need for increased mixed-waste treatment capability, the Department of Energy (DOE) Albuquerque Operations Office (AL) organized a Treatment Selection Team to match mixed wastes with treatment options and develop a strategy for treatment of its mixed waste. The strategy developed by the Treatment Selection Team was to use off-site commercial treatment facilities where available; and for those wastes which could not be treated using commercial treatment facilities, to develop mobile treatment capability to treat the wastes at the DOE-AL sites where the wastes were generated, eliminating the necessity for shipment of wastes from one site to another. The development of mobile waste treatment capability included the development and demonstration of treatment technologies for use with mixed wastes. Responsibility for development of several of these technologies was assigned to the DOE Grand Junction Projects Office (GJPO) under the Mixed-Waste Treatment Program (MWTP). One of the wastetreatment technologies assigned to GJPO was evaporative oxidation (EO), which is used primarily in the treatment of aqueous wastes containing hazardous organic compounds.

Rust Geotech, contractor to DOE-GJPO, conducted pilot-scale EO treatability testing using the Rustpatented $\mathrm{PO} * \mathrm{WW} * \mathrm{ER}$ process. Information obtained from the treatability testing was used to design a full-scale PO*WW*ER mobile treatment unit (MTU). The PO*WW*ER MTU uses evaporation to separate organics and water from radionuclides and solids, and oxidation to convert the hazardous organics into innocuous byproducts.

A Process Hazards Analysis (PHA) is required for each MTU being developed. The objective of the PHA and this report is to demonstrate that a thorough assessment of the risks associated with the operation of the PO*WW*ER MTU has been performed and documented. This report has been prepared according to the methodology and report format guidelines provided in the DOE-AL Guidance for the Preparation of MWT Process Hazards Analysis (DOE 1995b).

Prior to initiation of the PHA, a detailed analysis of hazards associated with operation of the MTU was undertaken. The most significant potential hazards identified by this analysis were (1) foaming in the evaporator could result in carryover of liquid into the oxidizer heaters, which in turn could cause an explosion due to thermal stresses in the heaters; and (2) low or no flow in the Econobator inlet line, which could create an explosive situation due to high propane concentration. These hazards were mitigated by changes to the design (additional foam sensors and level indicators for the evaporator, and deletion of the propane addition system). The remaining potential hazards were evaluated for design improvements to further reduce their frequency and/or severity. No further action is required to reduce risks associated with these hazards.

The PHA evaluated a number of accident scenarios not directly related to the operation of the MTU, such as damage from natural phenomena (e.g., earthquakes) and from mishandling chemical containers. The worst-case accident scenarios were then evaluated to determine the risk potential to the MTU and to co-located workers, the public, and the environment. On the basis of this analysis, the overall risk to any population group from operation of the PO*WW*ER MTU has been determined to be very low. The MTU is classified as a Radiological Facility (i.e., less than a Hazard Category 3 facility), with low hazards (i.e., minor on-site impacts to people, with no impact to off-site people or the environment).

This PHA is considered adequate as the only safety basis documentation (i.e., a supplemental safety analysis and/or a full scope safety analysis report is not required) for supporting DOE authorization to operate the PO*WW*ER MTU at all DOE user sites. No further safety basis documentation is needed. 
This page intentionally blank 


\section{Abbreviations, Acronyms, and Initialisms}

\begin{tabular}{|c|c|}
\hline AIT & autoignition temperature \\
\hline AL & Albuquerque Operations Office \\
\hline ASA & Auditable Safety Analysis \\
\hline atm & atmosphere \\
\hline BP & boiling point \\
\hline${ }^{\circ} \mathrm{C}$ & degrees Celsius \\
\hline $\mathrm{cal} / \mathrm{g}$ & calories per gram \\
\hline CEDE & committed effective dose equivalent \\
\hline CFR & U.S. Code of Federal Regulations \\
\hline $\mathrm{Ci}$ & curie(s) \\
\hline $\mathrm{Ci} / \mathrm{g}$ & curie(s) per gram \\
\hline $\mathrm{CO}$ & carbon monoxide \\
\hline DBA & design basis accident \\
\hline DCN & Design Change Notice \\
\hline $\mathrm{D} \& \mathrm{D}$ & decontamination and decommissioning \\
\hline DOE & U.S. Department of Energy \\
\hline DOT & U.S. Department of Transportation \\
\hline $\mathrm{dp}$ & differential pressure \\
\hline EBSC & evaluation basis site characteristics \\
\hline EBWC & evaluation basis waste characteristics \\
\hline EO & evaporative oxidation \\
\hline EPA & U.S. Environmental Protection Agency \\
\hline ERPG & Emergency Response Planning Guidelines \\
\hline ESF & engineered safety features \\
\hline${ }^{\circ} \mathrm{F}$ & degrees Fahrenheit \\
\hline FFCA & Federal Facilities Compliance Act \\
\hline $\mathrm{fp}$ & flash point \\
\hline $\mathrm{ft}$ & foot (feet) \\
\hline $\mathrm{ft}^{2}$ & square foot (feet) \\
\hline $\mathrm{ft}^{3}$ & cubic foot (feet) \\
\hline FXETIBO & $\begin{array}{l}\text { fire, explosion, environmental damage, toxic release, bodily injury, business loss, } \\
\text { operability loss }\end{array}$ \\
\hline gal & gallon(s) \\
\hline $\mathrm{gal} / \mathrm{h}$ & gallon(s)s per hour \\
\hline $\mathrm{gal} / \mathrm{min}$ & gallon(s) per minute \\
\hline GJPO & Grand Junction Projects Office \\
\hline $\mathrm{h}$ & hour(s) \\
\hline HASP & health and safety plan \\
\hline HAZOP & hazards and operability analysis \\
\hline HEPA & high-efficiency particulate air \\
\hline ICRP & International Commission on Radiological Protection \\
\hline $\mathrm{IDLH}$ & immediately dangerous to life or health \\
\hline IH & Industrial Hygienist \\
\hline KAFB & Kirkland Air Force Base \\
\hline $\mathrm{kg}$ & kilogram(s) \\
\hline $\mathrm{kg} / \mathrm{m}^{3}$ & kilogram(s) per cubic meter \\
\hline $\mathrm{km}$ & kilometer(s) \\
\hline
\end{tabular}




\section{Abbreviations, Acronyms, and Initialisms (continued)}

\begin{tabular}{|c|c|}
\hline $\mathrm{km} / \mathrm{h}$ & kilometer(s) per hour \\
\hline LANL & Los Alamos National Laboratory \\
\hline lb & pound(s) \\
\hline $\mathrm{lb} / \mathrm{ft}^{3}$ & pounds per cubic foot \\
\hline LDR. & land disposal restriction \\
\hline LEL & lower explosive limit \\
\hline LFC & lowest feasible concentration \\
\hline LTA & less than adequate \\
\hline m & meter(s) \\
\hline MAR & material at risk \\
\hline$\mu \mathrm{Ci} / \mathrm{g}$ & microcurie(s) per gram \\
\hline $\mathrm{mb}$ & millibar(s) \\
\hline $\mathrm{mi}$ & mile(s) \\
\hline $\mathrm{m}^{3}$ & cubic meter(s) \\
\hline $\mathrm{m}^{3} / \mathrm{h}$ & cubic meter(s) per hour \\
\hline $\mathrm{mm}$ & millimeter(s) \\
\hline mrem & milliroentgen(s) \\
\hline $\mathrm{mrem} / \mathrm{h}$ & milliroentgen(s) per hour \\
\hline $\mathrm{m} / \mathrm{s}$ & meter(s) per second \\
\hline MTU & mobile treatment unit \\
\hline mw & molecular weight \\
\hline MWT & mixed-waste treatment \\
\hline MWTP & Mixed-Waste Treatment Program \\
\hline NA & not applicable \\
\hline $\mathrm{nCi} / \mathrm{g}$ & nanocuries per gram \\
\hline $\mathrm{NO}_{\mathrm{x}}$ & nitrogen oxide \\
\hline O\&MI & operation and maintenance \\
\hline OSHA & Occupational Safety and Health Administration \\
\hline NRC & U.S. Nuclear Regulatory Commission \\
\hline PCB & polychlorinated biphenyl \\
\hline PFD & process flow diagram \\
\hline P\&ID & piping and instrumentation diagram \\
\hline$\dot{\mathrm{p}} \mathrm{Ci} / \mathrm{g}$ & picocuries per gram \\
\hline PHA & Process Hazards Analysis \\
\hline PM & preventive maintenance \\
\hline PPE & personal protective equipment \\
\hline ppm & parts per million \\
\hline PSE & pressure safety element \\
\hline PSV & pressure safety valve \\
\hline psia & pounds per square inch absolute \\
\hline psig & pounds per square inch gauge \\
\hline PTX & Pantex \\
\hline $\mathrm{Pu}$ & plutonium \\
\hline QA/QC & quality assurance/quality control \\
\hline RAD & radiologic \\
\hline $\begin{array}{l}\text { RCRA } \\
\text { rem }\end{array}$ & $\begin{array}{l}\text { Resource Conservation and Recovery Act } \\
\text { roentgen(s) }\end{array}$ \\
\hline RMWMF & Radioactive and Mixed Waste Management Facility \\
\hline RMMA & radioactive material management area \\
\hline
\end{tabular}




\section{Abbreviations, Acronyms, and Initialisms (continued)}

$\begin{array}{ll}\text { RQ } & \text { reportable quantity } \\ \text { SAR } & \text { safety analysis report } \\ \text { SCR } & \text { silicon-controlled rectifier } \\ \text { SNL/NM } & \text { Sandia National Laboratories/New Mexico } \\ \text { SOP } & \text { standard operating procedure } \\ \text { SSC } & \text { structure, system, or component } \\ \text { STEL } & \text { short-term exposure limit } \\ \text { SVOC } & \text { semivolatile organic compound } \\ \text { TA-3 } & \text { Technical Area 3 } \\ \text { TD } & \text { thermal desorption } \\ \text { TSCA } & \text { Toxic Substance Control Act } \\ \text { TSR } & \text { technical safety requirement } \\ \text { TWA } & \text { time-weighted average } \\ \text { U } & \text { uranium } \\ \text { UEL } & \text { upper explosive limit } \\ \text { UBC } & \text { Uniform Building Code } \\ \text { USQ } & \text { unreviewed safety question } \\ \text { VOC } & \text { volatile organic compound } \\ \text { vp } & \text { vapor pressure } \\ \text { wt. \% } & \text { weight percent }\end{array}$


This page intentionally blank 


\subsection{Introduction}

\subsection{Scope}

In 1992, Congress passed the Federal Facilities Compliance Act (FFCA) that requires the U.S. Department of Energy (DOE) to treat and dispose of its mixed waste in accordance with the Resource Conservation and Recovery Act (RCRA) land disposal restrictions (LDRs). Adequate treatment capability does not currently exist to treat the mixed wastes that are generated and stored at the nine sites under DOE Albuquerque Operations Office (AL) oversight. In response to the need for increased mixed-waste treatment capability, DOE-AL organized a Mixed-Waste Treatment Program (MWTP) to match mixed wastes with treatment options and develop a strategy for treatment of its mixed waste.

The strategy developed by the MWTP, as described in the AL Mixed-Waste Treatment Plan (DOE 1994), was to use available off-site commercial treatment facilities where possible and, where commercial treatment facilities could not be used, to develop mobile treatment capability to treat wastes at the DOE-AL sites where wastes are generated. Treatment processes used for mixed waste must not only address the hazardous component to comply with LDRs, but must also contain the radioactive component in a form that allows final disposal while protecting workers, the public, and the environment.

On the basis of recommendations of the Treatment Selection Team, the MWTP assigned projects to various DOE-AL sites to bring mixed-waste treatment on line. One of the technologies assigned to the DOE Grand Junction Projects Office (GJPO) for development was evaporative oxidation (EO). Rust Geotech, contractor to DOE-GJPO, conducted pilot-scale EO treatability testing with the Rust-patented $\mathrm{PO} * \mathrm{WW} * \mathrm{ER}$ process. Information gained from the treatability testing was used to design a full-scale PO*WW*ER mobile treatment unit (MTU).

The overall scope of this $P O^{*} W W^{*} E R$ MTU Process Hazards Analysis (PHA) report is to document the hazards analysis performed by GJPO on the PO*WW*ER MTU. To date, the DOE-AL sites that plan to use the PO*WW*ER MTU for treating their mixed waste inventories are Los Alamos National Laboratory (LANL), Sandia National Laboratories/New Mexico (SNL/NM), and Pantex (PTX).

The PO*WW*ER process, an EO technology, is designed to treat aqueous mixed waste streams containing volatile organic compounds (VOCs), semivolatile organic compounds (SVOCs), volatile inorganics, and dissolved or suspended solids that may contain heavy metals and radionuclides. The mixed waste treatment process combines three essential unit operations: (1) evaporation; (2) catalytic oxidation; and (3) gas scrubbing. The evaporator concentrates the nonvolatiles by vaporizing most of the water along with the volatile constituents. The catalytic Econobator (oxidation unit) converts the volatilized contaminants into water, carbon dioxide, and trace quantities of acid gas. The acid gas is then neutralized and removed as a salt in the gas scrubber.

The process products include: (1) the brine from the evaporator which contains the concentrated radionuclides; (2) the "blowdown" from the scrubber containing sodium halide and sodium hydroxide; and (3) the vent gas and combustion products.

Figure 1-1 is a Process Flow Diagram (PFD) that graphically illustrates the EO process. The following description highlights the engineering features that make the system a unique mixed waste treatment process. Although this is the first mixed waste application for the EO technology, this is not the first unit to be constructed for treatment. Three $\mathrm{PO} * \mathrm{WW} * \mathrm{ER}$ units have been fabricated and operated to date. A 1-gallon-per-minute (gal/min) unit in Lake Charles, Louisiana; a 50-gal/min unit in Hong Kong, China; 
and a 1.5-gallon-per-hour (gal/h) test unit (the "mini-PO*WW*ER unit," which was used for the treatability tests at GJPO) based in Clemson, South Carolina. The Hong Kong unit is the only one in fullscale treatment of industrial hazardous aqueous waste. The smaller units are used exclusively for treatability studies.

\subsection{Objectives}

The overall EO project objective is to bring the PO*WW*ER MTU on line for treating DOE mixed-waste inventories, therefore enabling specific DOE-AL sites to meet their FFCA commitments.

The objective of this PHA report is to demonstrate that a thorough assessment of the risks associated with the operation of the PO*WW*ER MTU has been performed and documented. This report has been prepared according to the methodology and report format guidelines provided in the DOE-AL Guidance for the Preparation of MWT Process Hazards Analysis (DOE 1995b). 


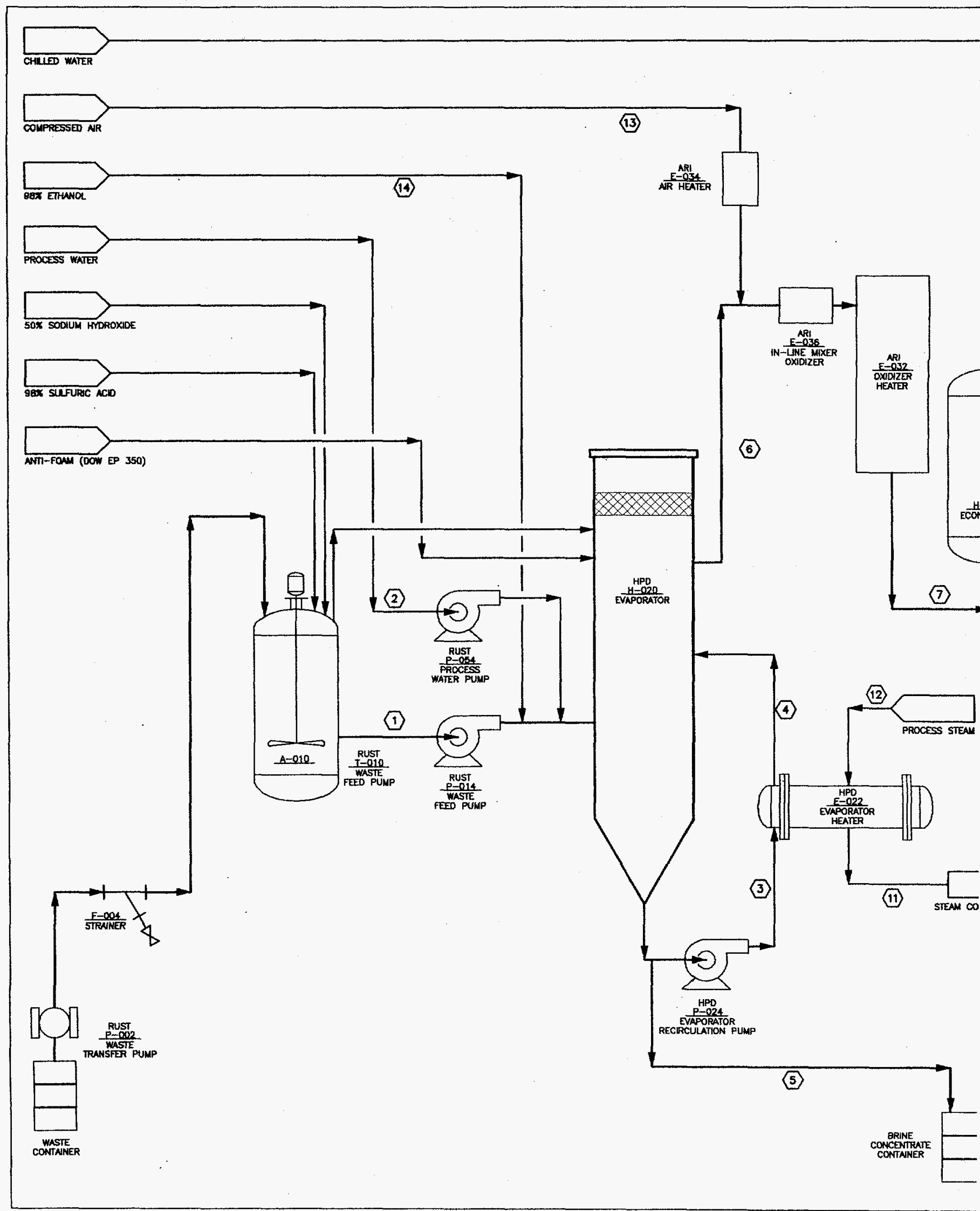




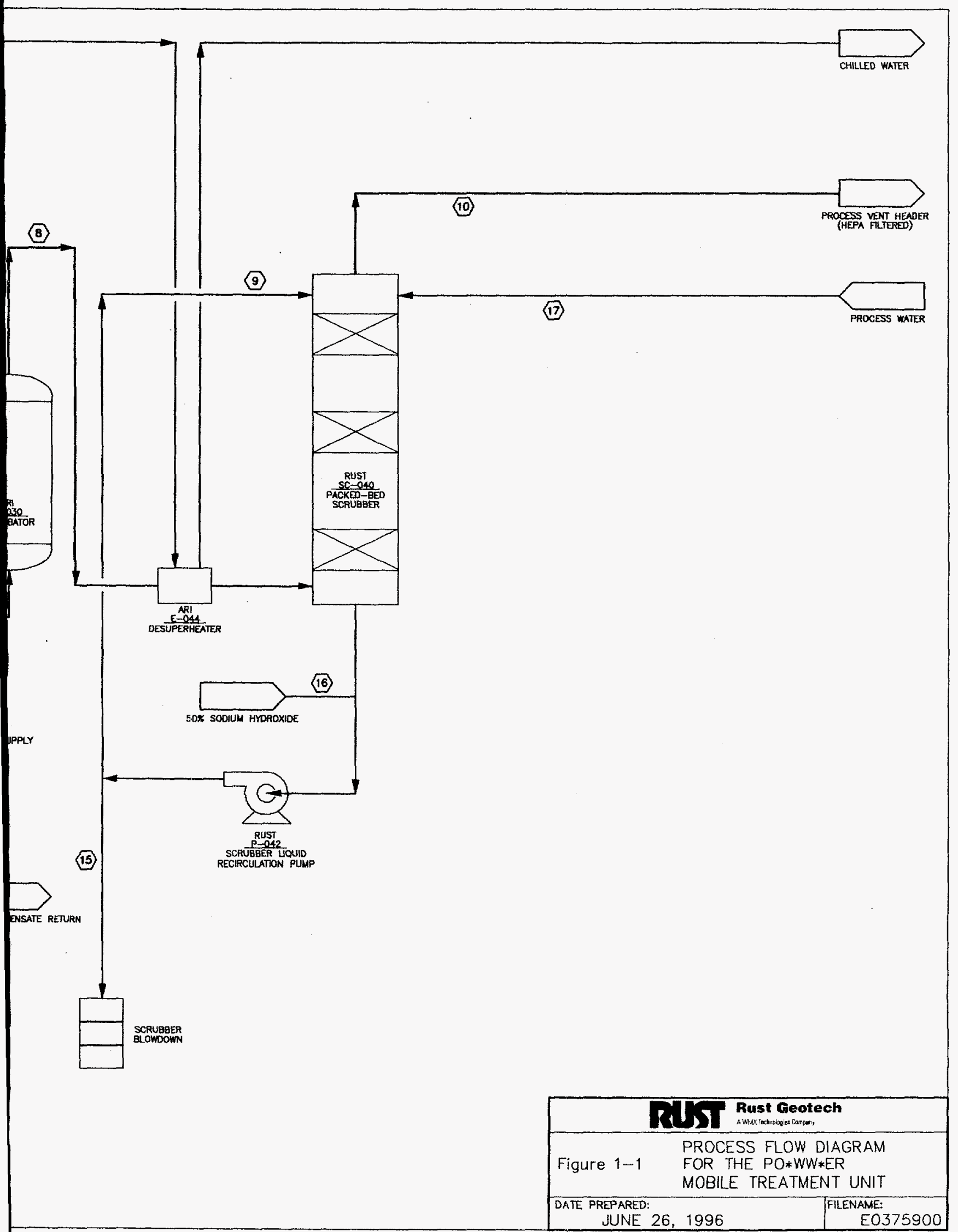

PO*WW*ER MTU Process Hazards Analysis 


\subsection{Site Description}

\subsection{Site Information}

The PO*WW*ER MTU is proposed for use at three DOE-AL sites: Los Alamos National Laboratory (LANL), Sandia National Laboratories/New Mexico (SNL/NM), and Pantex (PTX). The MTU is designed to be housed in a climate-controlled environment and is not suitable for outdoor use. However, barometric pressures, seismic zones, and maximum ambient temperatures were taken into account during the design. Locations, elevations above sea level in feet (ft) and meters (m), average barometric pressures in millibars (mb) and pounds per square inch absolute (psia), seismic zone designations, and reasonable maximum . temperature in degrees Fahrenheit $\left({ }^{\circ} \mathrm{F}\right)$ for the three sites proposed for MTU treatment operations are

\section{LANL}

- Location - Los Alamos, New Mexico

- $\quad$ Elevation $-7,300 \mathrm{ft}(2,225 \mathrm{~m})$

- $\quad$ Average barometric pressure $-779 \mathrm{mb}(11.3 \mathrm{psia})$

- $\quad$ Seismic zone: $2 B$

- Reasonable maximum temperature $-88^{\circ} \mathrm{F}$

\section{SNL/NM}

- Location - Albuquerque, New Mexico

- $\quad$ Elevation $-4,958 \mathrm{ft}(1,511 \mathrm{~m})$

- Average barometric pressure $-841 \mathrm{mb}$ (12.2 psia)

- Seismic zone: $2 B$

- Reasonable maximum temperature $-98^{\circ} \mathrm{F}$

\section{PTX}

- $\quad$ Location - Amarillo, Texas

- Elevation $-3,600 \mathrm{ft}(1098 \mathrm{~m})$

- $\quad$ Average barometric pressure $-889 \mathrm{mb}$ (12.9 psia)

- Seismic zone: 1

- Reasonable maximum temperature $-101^{\circ} \mathrm{F}$ 
Because SNL/NM has provided more site-specific information and has proposed a specific building to house the PO*WW*ER MTU for treating its mixed-waste inventories, SNL/NM was chosen for the site-specific risk assessment. Because LANL and PTX have not determined where the MTU will be located on site, analyses were conducted in a very conservative manner to ensure all sites could apply the results to their facilities. Appendix A presents the site characteristics used for the evaluation basis of the risk assessment. Site-specific risk assessment evaluations of each MTU user site will be required during permitting activities and before transporting the MTU to the user site.

\subsubsection{SNL/NM Site Description}

The PO*WW*ER MTU will be located within the SNL/NM Radioactive and Mixed Waste Management Facility (RMWMF) in Technical Area 3 (TA-3). The RMWMF is in the southeast corner of TA-3 and consists of Buildings 6920 and 6921, two skid-mounted storage buildings for reactive and ignitable/flammable waste, a 4,000-square-foot $\left(\mathrm{ft}^{2}\right)$ prefabricated waste storage building, a 7,000-gallon (gal) fuel-storage tank, an office trailer, and a rubber-lined retention basin. The location of these facilities are shown in Figure 2-1.

\section{Mixed-Waste Treatment Location}

Building 6920 is the principal structure in the RMWMF. Treatment of mixed waste with the PO*WW*ER MTU is planned to be performed in the north bay of Building 6920. No ignitable, flammable, or reactive waste will be stored in Building 6920. Two skid-mounted storage buildings, for storage of reactive and ignitable/flammable waste, are located approximately $100 \mathrm{ft}$ to the northeast and northwest of Building 6920 , respectively.

The primary radiological buffer area for Building 6920 has been engineered to minimize the generation of airborne contamination and the spread of contamination. Pressure zones are maintained throughout the building to cause air to flow from areas of no airborne contamination to areas of progressively greater potential for airborne contamination. Air from the north bay is exhausted through one stage of prefilters and high-efficiency particulate air (HEPA) filters.

\section{Geography}

SNL/NM is on Kirtland Air Force Base (KAFB), which is located in Bernalillo County, New Mexico. $\mathrm{KAFB}$ is bordered on the north and west by densely populated residential areas of Albuquerque. To the east of KAFB is the Four Hills residential area of Albuquerque. To the south of KAFB is the Isleta Indian Reservation and Valencia County. Valencia County is a rural, sparsely populated area. Surrounding populations, as of 1990 , were as follows:

$\begin{array}{lr}\text { Bernalillo County: } & 480,577 \\ \text { Albuquerque: } & 384,736 \\ \text { Isleta Reservation: } & 2,915 \\ \text { Valencia County: } & 45,235 \\ \text { KAFB: } & 5,761\end{array}$

The metropolitan population center closest to SNL/NM is Albuquerque, located along the northern boundary of the site (Figure 2-2). Distances from the RMWMF to the nearest KAFB housing and the nearest Albuquerque residential housing are approximately 9.2 kilometers $(\mathrm{km})$ or 5.7 miles $(\mathrm{mi})$ and 
$8.5 \mathrm{~km}(5.3 \mathrm{mi})$, respectively. The nearest on-site individual is located about $300 \mathrm{~m}$ northeast of the RMWMF. The nearest boundary to public land is approximately $2.8 \mathrm{~km}(1.7 \mathrm{mi})$ to the south. The main east-west runway of the Albuquerque/KAFB airport lies $8.5 \mathrm{~km}(5.3 \mathrm{mi})$ north-northwest of the RMWMF.

\section{Meteorology}

SNL/NM and KAFB are located in the Albuquerque-Belen Basin which is characterized by low precipitation; wide temperature extremes; frequent, dry winds; and occasional heavy rain showers. Strong winds usually occur in late winter and early spring. Wind speeds reach a velocity of 50 kilometers per hour $(\mathrm{km} / \mathrm{h})$ on an average of 46 days per year. Every 2 years, a 1 -minute duration gust of $97-\mathrm{km} / \mathrm{h}$ wind is expected. Prevailing surface winds on KAFB are from the east.

\section{Surface Hydrology}

The major surface hydrologic feature in central New Mexico is the Rio Grande River, which flows north to south through Albuquerque and lies approximately $10 \mathrm{~km}(6.2 \mathrm{mi})$ west of KAFB. Water from the Rio Grande River is used primarily for irrigation of agricultural crops. There are no continuously running streams on SNL/NM property.

\section{Subsurface Hydrology}

A fault complex (including a normal fault and an inferred fault) separates the regional aquifer system into a deeper zone west of the faults and a relatively shallower zone east of the faults. The depth to groundwater underlying SNL/NM facilities varies from approximately 15 to $30 \mathrm{~m}$ east of the faults and from approximately 116 to $153 \mathrm{~m}$ west of the faults.

\subsection{RCRA Site Permitting}

The sites currently targeted to receive the PO*WW*ER MTU for treatment of mixed wastes all possess a RCRA permit for some form of treatment, storage, or disposal. As a result, it is expected that permitting of the MTU can be accomplished through a modification to the existing RCRA permits. PO*WW*ER MTU technical information required for modifying the RCRA permits is provided in the $P O^{*} W W^{*} E R$ Mobile Treatment Unit Design Report (DOE 1996b). The MWTP Manager will provide the technical information to DOE-AL, and DOE-AL will make the information available to the user sites to assist the sites in preparing the required permit modifications.

The PO*WW*ER MTU user sites must obtain a RCRA permit modification for operation of the unit. RCRA Section 3005(a), as amended by the Hazardous and Solid Waste Amendments of 1984, requires owners and operators of all hazardous waste treatment, storage, and disposal facilities to obtain a RCRA permit prior to installing the MTU at a RCRA facility. The MTU may be prefabricated and transported to the proposed treatment site; however, construction on the site itself, such as pouring concrete foundations and connecting the MTU to physical structures on site, cannot occur until the RCRA operation permit is issued (RCRA Section 1004[2]). 


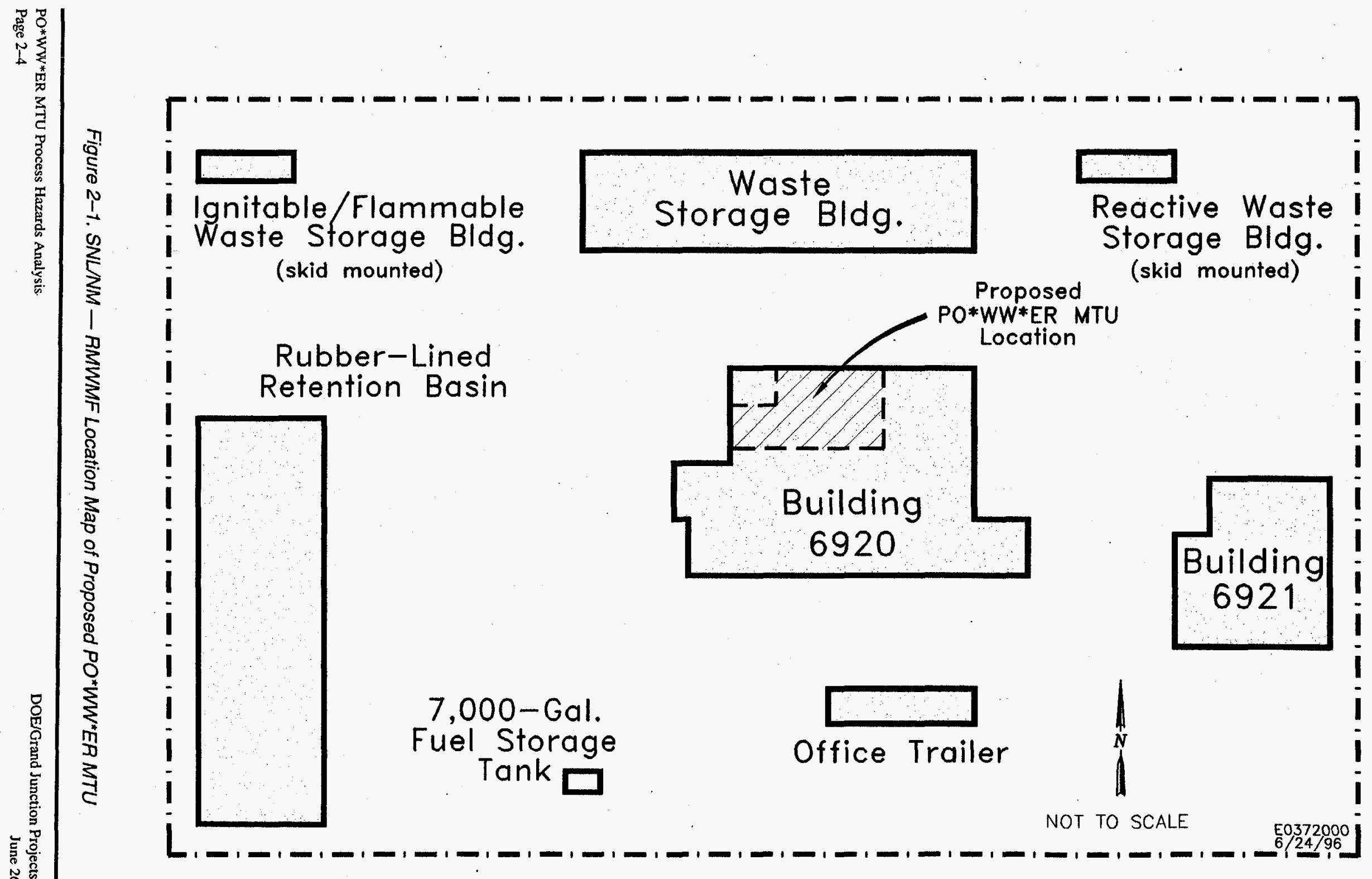




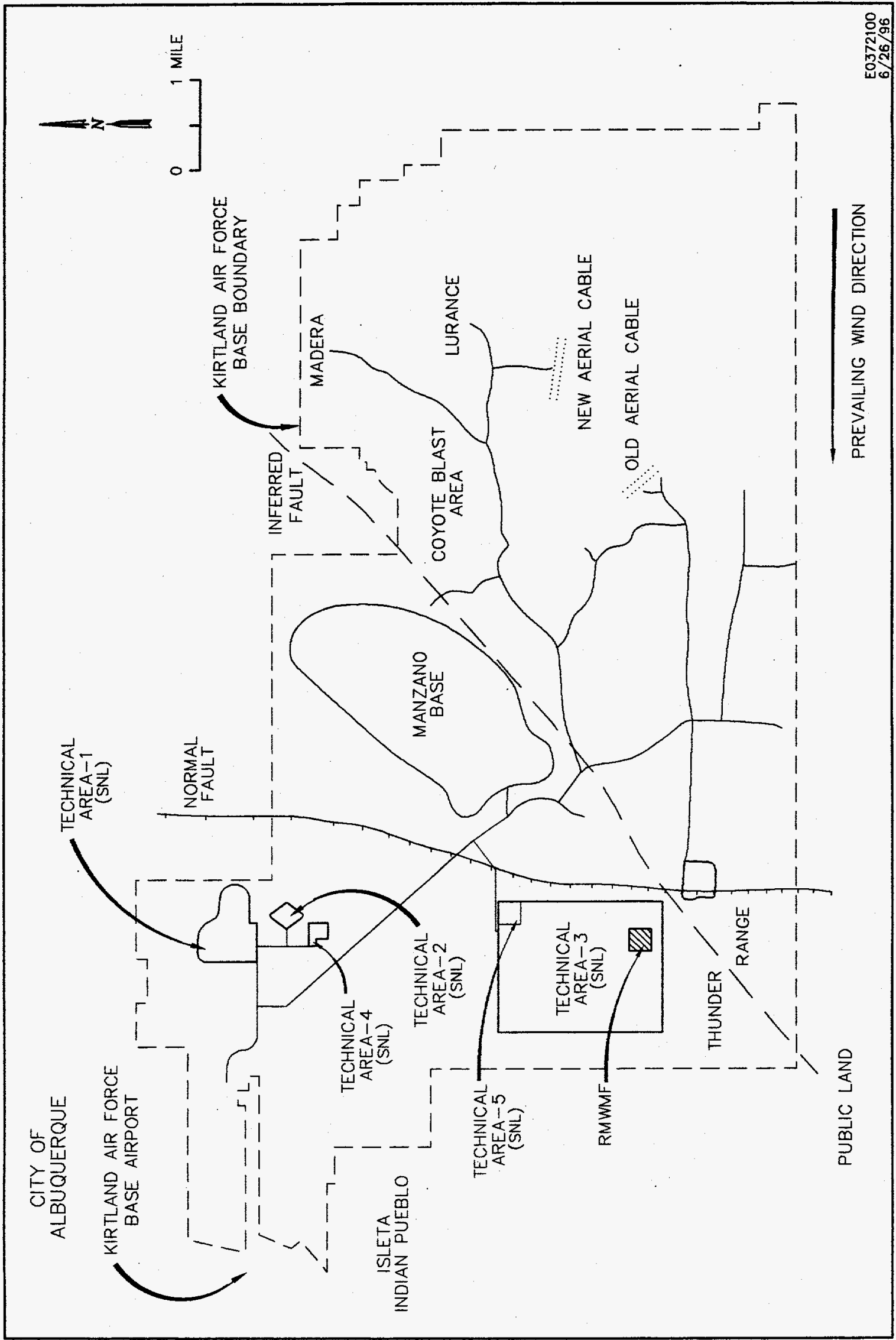

Figure 2-2. Sandia National Laboratories/New Mexico-Location Map 
This page intentionally blank 


\subsection{Process Description}

\subsection{PO*WW*ER Mixed-Waste Treatment Process}

The PO*WW*ER MTU utilizes Rust's patented PO*WW*ER EO technology to treat aqueous mixed waste streams containing VOCs, SVOCs, volatile inorganics, and dissolved or suspended solids that may contain heavy metals and radionuclides. VOCs and SVOCs are vaporized and destroyed at efficiencies as high as $\mathbf{9 9 . 9 9 9 5}$ percent, and the harmless products are vented to the atmosphere along with most of the water from the original waste feed. The volume of the concentrated brine, which contains the nonvolatile constituents and is suitable for stabilization, will be less than 5 percent of the volume of the original waste. The technology combines three unit operations: (1) evaporation; (2) catalytic oxidation; and (3) gas scrubbing.

Aqueous mixed-waste is fed to the evaporator which is of forced-circulation design and operates at a slight positive pressure. The evaporator vaporizes the volatile constituents along with most of the water. The nonvolatiles, including radionuclides, dissolved and suspended solids, and heavy metals, are retained in the evaporator and are periodically discharged as a concentrated brine. Dilution water, to control the Econobator bed temperature, and ethanol, which serves as a halide scavenger to maximize catalyst life, also are added in the evaporator. The evaporator is designed to prevent foaming and carryover of radionuclides.

The Econobator (catalytic oxidation) section includes the feed and air heaters, the catalytic Econobator, and the desuperheater. The aqueous waste and air makeup are heated to between 400 and $650{ }^{\circ} \mathrm{C}$, depending on the heating value of the waste, in the feed and air heaters. The waste/air mixture then enters the catalytic Econobator, a fluidized-bed reactor in which the volatilized organic contaminants are catalytically converted into water, carbon dioxide, and trace quantities of acid gas. The temperature of the Econobator is controlled by adjusting the input of the heaters, and the temperature rise is controlled by adjusting the amount of dilution water added to the evaporator. The off gases from the Econobator pass through the desuperheater, in which they are cooled from $650^{\circ} \mathrm{C}$ to approximately $150^{\circ} \mathrm{C}$, before passing on to the scrubber.

The acid-gas scrubber is a packed column in which acid gases (chiefly hydrogen chloride) produced from oxidation of volatile waste compounds are neutralized. The medium for neutralization is a weak solution of sodium hydroxide which is circulated counter currently in the scrubber. The neutralized acids are removed as a salt solution, and the remaining gases are vented to the atmosphere.

The process products include the brine from the evaporator which contains the concentrated radionuclides, the "blowdown" from the scrubber containing sodium halide and sodium hydroxide; and the vent gas which contains combustion products and water.

\subsubsection{Feed Rate}

The maximum waste feed flow rate of the PO*WW*ER MTU covered in this design is $20 \mathrm{gal} / \mathrm{h}$. This rate was based on the streams listed in the DOE-AL mixed waste inventory which were designated for PO*WW*ER as of the time the DDR was prepared. Treatment times based on those waste volumes were on the order of one to two weeks per waste stream. Waste inventories and treatment options have been extensively revised since that time, with the consequence that all DOE-AL mixed-waste streams that would be possible candidates for treatment using PO*WW*ER have been designated for other treatment options. Continued design of the PO*WW*ER MTU uses the original design basis on the assumption that 
use of outside commercial treatment facilities will prove unfeasible or highly uneconomic for at least some of the DOE-AL aqueous mixed wastes.

\subsubsection{Operating Cycle}

PO*WW*ER is a continuous process requiring about eight hours just to start up and shut down, so around-the-clock operation is essential. Operation of the MTU must be performed according to the operation and maintenance (O\&M) procedures to be prepared prior to the operation of the MTU at user sites. Hereafter in this PHA, the O\&M procedures are referred to as standard operating procedures (SOPs).

The MTU must be started up using only water as feed, and the evaporator and Econobator must reach a steady state with water feed before any waste is introduced. The SOPs will not allow any latitude on this point; starting up with waste feed will not be permitted under any circumstances. During this startup period, there is no need to add ethanol to the evaporator, or to add sodium hydroxide to the scrubber. Once the MTU has stabilized with water feed at $20 \mathrm{gal} / \mathrm{h}$, waste will be gradually introduced, replacing water feed with waste feed on a 1:1 basis, until the optimum waste feed rate is achieved. During this time, ethanol and/or sodium hydroxide feed may also be initiated if required.

Shutdown of the MTU also requires operation on water feed only. The waste feed is discontinued and operation continues using only water to strip residual organics from the evaporator. The period of water feed will normally lașt two to six hours, but longer periods of water feed may be required if the waste feed contained semivolatiles. Ethanol is not required during this period, and sodium hydroxide consumption will very quickly drop to zero as the remaining organics are consumed.

Evaporator brine is removed from the area in sealed drums as required, although it is anticipated that the volume of evaporator brine will not exceed $55 \mathrm{gal}$ until the evaporator is drained at the end of a waste run. Scrubber blowdown also is removed as needed. However, there is no process requirement to drain the scrubber between waste runs, because it will contain no radionuclides or hazardous constituents. Combining the scrubber blowdown from several waste runs into a single drum thus does not constitute mixing hazardous-waste streams.

\subsubsection{Waste Characteristics}

The PO*WW*ER MTU can treat organic and inorganic (e.g. ammonia) compounds having normal boiling points equal to or lower than $100^{\circ} \mathrm{C}$. Semivolatile compounds, having normal boiling points higher than $100^{\circ} \mathrm{C}$, can be treated with PO*WW*ER although such compounds will accumulate in the evaporator. Semivolatile compounds that have boiling points relatively close to that of water may reach a steady-state concentration in the evaporator when the equilibrium concentration in the vapor leaving the evaporator equals the concentration in the feed liquid. Treatment of higher-boiling semivolatiles will require feeding waste in a "semi-batch" mode alternating periods of waste feed with periods where only water is fed to allow the semivolatile(s) to be stripped from the evaporator.

\subsection{Treatment of Radioactive Waste By-Products}

The liquid products of the $\mathrm{PO} \mathrm{WWW}^{*} \mathrm{ER}$ process are the evaporator "brine" (the circulating solution in the evaporator) and the blowdown liquid from the scrubber. The PO*WW*ER process is designed to contain nonvolatile radionuclides within the evaporator. The evaporator brine, which contains all radionuclides (with the exception of tritium), is purged off during operation as required to maintain the target specific gravity. At the end of treatment, residual organics are stripped from the brine by feeding water to the evaporator for 2 to 6 hours. 
Treatment with $\mathrm{PO} * \mathrm{WW} * \mathrm{ER}$ removes hazardous characteristics such as corrosivity, toxicity, and ignitability. The brine produced from treatment of wastes which exhibit such properties is not characteristic for those properties, and may be disposed of as radioactive waste if no other hazardous characteristics or underlying hazardous constituents are present. If the original waste contained any RCRA-listed hazardous constituents, the brine retains the listing(s) of the original waste. However, analysis of the brine should confirm that it meets RCRA LDRs for all listed constituents, so the brine may be disposed of as a radioactive waste. Any RCRA-regulated metals in the original waste concentrate in the evaporator. If the waste was RCRA-listed for metals, the evaporator brine is considered a mixed waste and requires additional treatment (e.g., stabilization) prior to disposal.

The scrubber blowdown liquid will be a weakly basic $(\mathrm{pH} \sim 8-9)$ salt solution. Based on the GJPO treatability tests, it is not expected to contain any hazardous organic compounds. However, some corrosion of the scrubber and the circulating piping is expected, and the products of corrosion will report to the circulating solution. The scrubber blowdown must be analyzed for RCRA-listed corrosion products (e.g., hexavalent chrome) before disposal.

The PO*WW*ER MTU waste acceptance criteria allows for treatment of mixed waste containing lowlevel ( $<100 \mathrm{nCi} / \mathrm{g})$ radioactivity. The evaporator can concentrate radionuclides by as much as 100 to 1 , so it is possible that the brine produced during treatment of a low-level waste may have a radioactivity level much higher than $100 \mathrm{nCi} / \mathrm{g}$. If the original waste contains a significant portion of transuranic elements, the brine will be transuranic. This will not affect the operation of the MTU in any way, nor will there be any potential for operator exposure to significant radiation dosages, but that fact should be considered prior to final disposal of the brine. See Attachment C.5.3-1 for the dose rate calculation report.

Based on the GJPO treatability tests, the scrubber blowdown liquid is not expected to be radioactive. The exception will occur if tritium is present in the mixed-waste feed. Tritium will either exist as tritiated water, or as tritiated organics that will be converted to tritiated water in the Econobator. When the scrubber is not in use (e.g., when the waste feed does not contain any halogenated organics), all of the tritiated water will be vented directly to the atmosphere along with the rest of the vaporized water and the water of reaction. The sites will have to confirm that the vented tritium does not exceed release limits. When the scrubber is in use, a portion of the vaporized water and the water of reaction, including any tritiated water present, partitions to the scrubber blowdown. Scrubber blowdown from treatment of wastes containing tritium will have to be tested for radiation levels, as well as for RCRA-listed corrosion products as described above, before final disposal requirements can be determined.

\subsection{Decontamination and Decommissioning Prior to Shipment to Next Host Site}

The interior and exterior surfaces of the PO*WW*ER MTU equipment are designed for decontamination between runs of dissimilar wastes and before shipping the MTU to the next host site. The MTU is designed to withstand frequent decontamination and decommissioning (D\&D) without damage to the equipment surfaces or functionality. Decontamination to meet health and safety, permitting, and transportation requirements will be accomplished primarily by draining and chemically flushing the equipment and, if necessary, by dismantling and physically cleaning select pieces of equipment.

The decontamination criteria for shipment of the PO*WW*ER MTU to the next host site will be the requirements for shipping the MTU as nonhazardous material, as defined by U.S. Department of Transportation (DOT) requirements and as low specific-activity material as defined by 49 CFR 173.403 . Free release of equipment in radioactive service is not expected. If the equipment is shown to have a specific activity of less than 2,000 picocuries per gram (pCi/g), it is not considered radioactive and may not require special DOT shipping requirements. 
In general, the equipment must be completely drained of all liquid, cleaned, sealed, and secured to facilitate shipment. There are no known unique hazards expected to arise as a result of the decontamination effort. Portable local ventilation can be provided to prevent either hazardous or radioactive material from becoming airborne. All decontamination work must be done inside a radioactive materials management area (RMMA).

The only equipment that will be radiologically contaminated are those items in the waste feed system (waste transfer pump, waste feed tank, and waste feed pump) and the evaporator system (evaporator, evaporator heater, and circulating pump). This equipment will be completely drained to satisfy RCRA requirements for empty equipment. The equipment comprising the evaporator system will be internally decontaminated by flushing with hot sodium bicarbonate, followed by rinsing with water. The spent bicarbonate solution and rinse water will be treated as a low-level radioactive waste. If necessary (e.g., if repeated bicarbonate rinses show continued high levels of radioactivity), the evaporator and the evaporator heater can be opened up and the internal surfaces physically decontaminated. The external surfaces of the evaporator system must be decontaminated to the limits given in 49 CFR 173.

Radiological contamination downstream of the evaporator system is not expected unless tritium was present in one or more of the waste streams. If tritium was not present in any waste, the catalyst and the scrubber liquid may be sampled if desired to confirm that they are nonradioactive. Equipment downstream of the evaporator system may be decontaminated for shipment by draining all free liquid and sealing open piping. The HEPA filters will be surveyed to confirm that they are not contaminated, and may then be reused at the next site. If tritium was present in one or more waste streams, the scrubber and all downstream piping must be purged with heated air (using the process air heater) for several hours to volatilize the tritium, and external surfaces must be surveyed to confirm that they conform to the limits given in 49 CFR 173. 


\subsection{Facility Description}

This section covers both primary and secondary containment. The primary containment includes sumps that are part of the design of the PO*WW*ER MTU. It is assumed that secondary containment will be provided by the host sites and is not included in the MTU design.

\subsection{Mixed Waste Treatment Skids}

The PO*WW*ER MTU skids are designed to be structurally stable to withstand the design basis earthquake, based on the SNL/NM and LANL seismic zone designations of $2 B$, and rigid to avoid damage during transit. Secondary containment must be a building large enough to house the skids. The building must be a RCRA-permitted building in compliance with DOE Standard DOE-SEO-1020-92, Natural Phenomena Hazards Design and Evaluation Criteria for Department of Energy Facilities, particularly for flood and wind design basis accidents (DBAs).

Figure 4-1 shows the layout of the skids for the PO*WW*ER MTU. The MTU is comprised of five primary skids: (1) the waste-feed tank skid; (2) the evaporator skid; (3) the Econobator skid; (4) the scrubber skid; and (5) the utilities skid. For purposes of determining the facility hazard classification (see Section 5), the MTU is divided into three segments, as shown on Figure 4-1. Segment 1 corresponds to Skid 1, Segment 2 to Skid 2, and Segment 3 to Skid 4. Skid 3 operates in vapor phase and contains less than 1 pound of vaporized organics, while Skid 5 is a utilities skid that does not contain any hazardous or radioactive materials, so neither of these skids is included in a hazard segment. The skid arrangement will occupy approximately $276 \mathrm{ft}^{2}$ of floor space within the secondary containment. Primary containment is provided by sumps to catch spills on Skids 1,2 , and 4 .

The PO*WW*ER MTU skids were designed by a registered structural engineer with more than 20 years experience, and were reviewed by a civil engineer knowledgeable in structural design with more than 12 years experience. The MTU skid design structural sketches, drawings, and calculations show centers of gravity, connection details, points of load application, and stresses in the structural members restraining the assemblies.

\subsection{Secondary Containment}

The PO*WW*ER MTU design does not include the design or specifications for secondary containment because the host sites will provide secondary containment compliant with RCRA (40 CFR 264) storage requirements, and will be able to meet the requirements for a radiological area. The materials at risk (MAR) and hazard classification analyses indicate no special structure is required. The structure will be designed to comply with DOE-STD-1020-92 for a Category I or II structure for the naturally occurring phenomena accidents for the particular site. Appendix A contains additional information on the requirements for the host-site structure and rationale for the structure specifications.

For seismic design, the worst case for sites hosting this MTU is SNL/NM and LANL, both situated in seismic zone $2 \mathrm{~B}$. The existing structures at SNL/NM and LANL are designed to withstand a Seismic Zone 2B earthquake through compliance with building codes such as the Uniform Building Code (UBC). A static force analysis was performed during the MTU design using methods described in the UBC. A performance category of either I or II, as defined by DOE-STD-1020-92, is appropriate for the building and the MTU because (1) there will be a low quantity of MAR, as discussed in Appendix B; (2) the operation can be instantly shut down and the MARs contained; and (3) the two levels of containment are not likely to be breached when the contaminants of concern are being processed. Based on the unmitigated 
accident analysis as presented in Appendix C.5, even if containment is breached, it is improbable that a life-threatening event would result. 


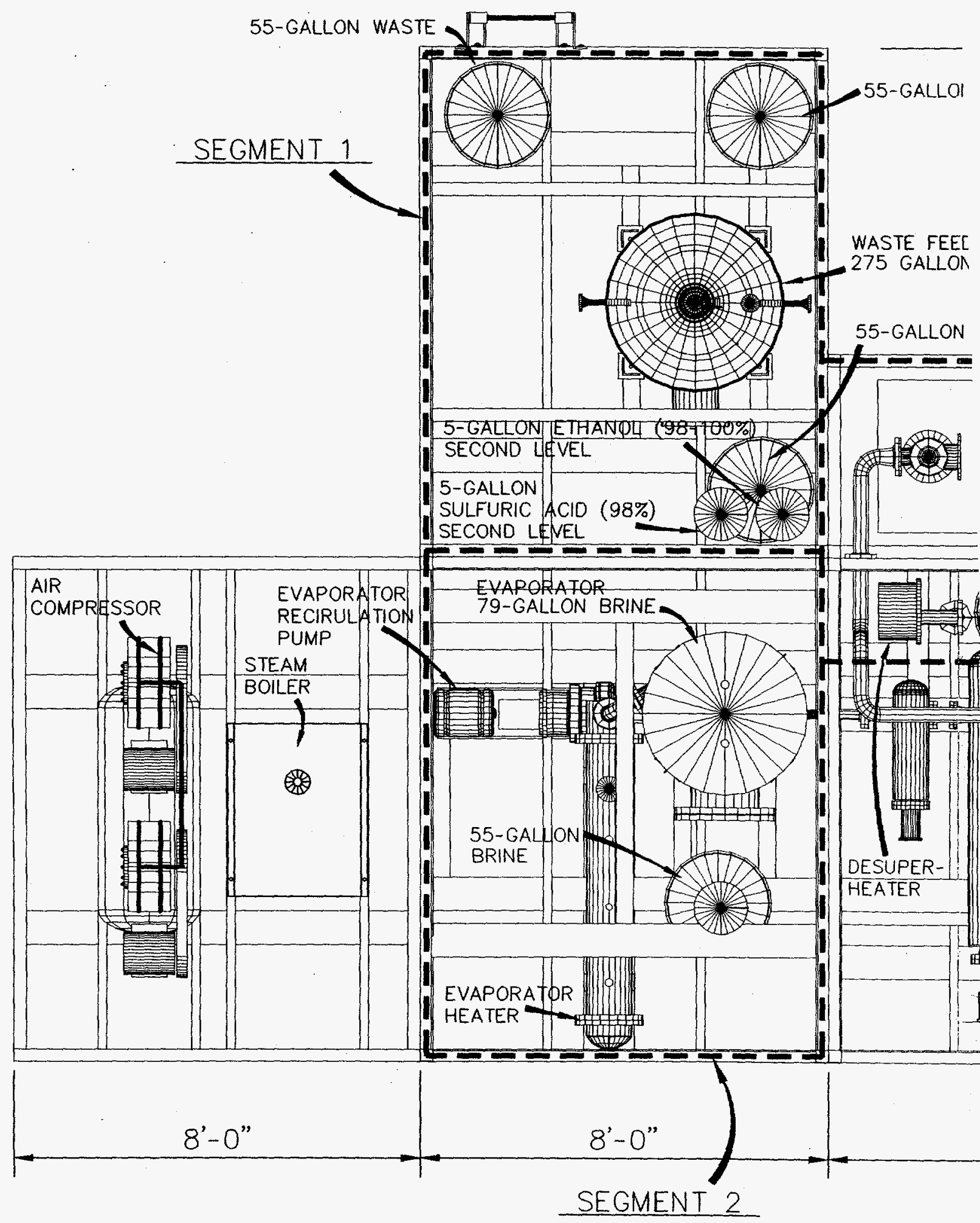




\section{SOLIDS}

\section{TANK}

WASTE

FODIUM HYOROXIDE (50\%)

PACKED-BED
SCRUBBER

-SEGMENT 3

55-GALLON SCRUBBER 11 BLOWDOWN
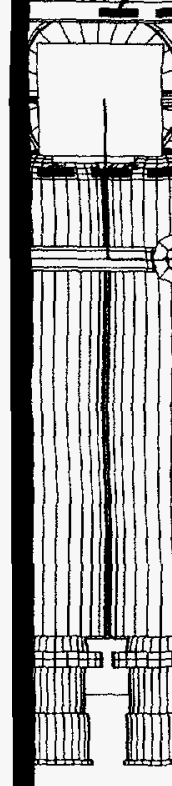

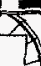
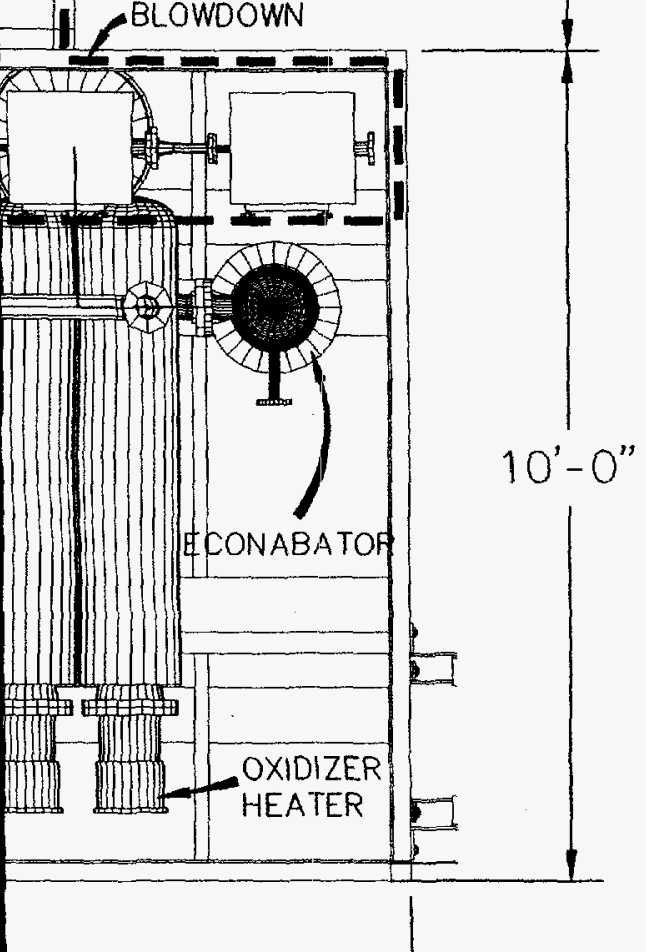

$8^{\prime}-0^{\prime \prime}$

\section{CID Rust Geotech}

PO*WW*ER MTU PLAN VIEW

Figure $4-1$

AND SEGMENTATION

FOR HAZARD CLASSIFICATION

DATE PREPARED:

JUNE 19,1996 


\subsection{Process Hazards Analysis Summary}

\subsection{Purpose}

The purpose of this PHA report is to provide a formal determination of facility class and hazard category for the PO*WW*ER MTU operation, identify the hazards of the operation, estimate the bounding unmitigated accident consequences, and evaluate the adequacy of safeguards and mitigating controls.

The PO*WW*ER MTU will be used to treat mixed wastes at LANL, SNL/NM, and PTX. This document provides a basis for the user sites to perform an unreviewed safety question analysis, as described in DOE Order 5480.21, Unreviewed safety Questions. This PHA determines whether additional site-specific safety analysis and/or a full scope safety analysis report (SAR) will be required prior to DOE authorization to operate the MTU. This PHA also provides the basis for changes to site-specific health and safety plans, process safety management programs, full scope SARs, or environmental assessments as needed.

The scope of this PHA is the operation of the PO*WW*ER MTU, including routine startup and shutdown. Commissioning, decommissioning, and transportation hazards associated with the MTU are outside the scope of this PHA because there will be no material at risk in the MTU during these activities.

Commissioning hazards will be analyzed during the readiness review processes (DOE Order 5480.31, Startup and Restart of Nuclear Facilities). Hazards specific to decommissioning the MTU will be handled through a task-specific decommissioning plan. Transportation hazard analysis will be controlled through a safety review of the MTU SOP and DOT requirements.

\subsection{Methodology}

The general PHA process entails data evaluation to determine material at risk; hazards identification, evaluation, and resolution; accident scenario analysis; and consequence analysis. These steps build one upon another to arrive at a determination of the degree of hazard involved in the process being studied.

The PO*WW*ER MTU PHA was performed according to the DOE-AL Guidance for the Preparation of MWT Process Hazards Analysis (DOE 1995b). DOE Standards 1027-92, 5502-94, and 3009-94 also were used to ensure the PHA met all requirements. The quantities of hazardous and radioactive substances for the MTU do not require compliance with 29 CFR 1910.119, "Process Safety Management of Highly Hazardous Chemicals," but the intent of this regulation was met as well.

The hazards and operability (HAZOP) analysis tool was chosen for the operating hazards identification, evaluation, and resolution portion of this PHA. HAZOP analysis provides a framework for the investigation of hazards using a methodical, meticulous investigative approach. The HAZOP analysis of the PO*WW*ER MTU was performed in July 1995, during conceptual design. Engineering and technical personnel from Rust Geotech, Rust Federal Services, and Wheelabrator Clean Air and Clean Water participated in the HAZOP analysis, under the direction of a facilitator from Rust Engineering. Section 5.3 describes the HAZOP analysis process and results.

During the weeks following the HAZOP analysis, Rust Geotech Engineering personnel resolved the action items identified during the HAZOP analysis and made changes to the design accordingly. Appendix C. 2 shows the tracking and resolution of all HAZOP analysis action items. At the time the PHA team met in April 1996, resolution of those hazards directly associated with the operation of the MTU that had been identified during the HAZOP analysis was essentially complete. The PHA therefore concentrated on 
identifying hazards indirectly associated with the operation (e.g., drum handling and damage due to external incidents such as forklift penetrations).

The PHA was developed by a Rust Geotech team with expertise in operations, engineering, health physics, industrial hygiene, and quality assurance. The following assumptions and variations to the DOE-AL PHA guidance document were used in the development of this PHA; these reflect the purpose and intent of the guidance document.

- This PHA was prepared late in the design stage, which affected the content of this report. For example, design change recommendations made as a result of the July 1995 HAZOP analysis had been incorporated in the design prior to performing the rest of the PHA. There were also changes to design made concurrent with the production of this report resulting from the PHA team meetings. Therefore, this report does not recommend actions to reduce risks. Recommended actions have already resulted in design changes to reduce the risks to acceptable levels, incorporate cost-effective features, and improve design operability.

- Hazards classification was based on conservative estimates using available data for MAR and the results of the unmitigated accident scenarios. Hazard classification is required by DOE Order 5480.23, Nuclear Safety Analysis Reports. DOE-STD-1027-92 (Hazard Categorization and Accident Analysis Techniques for Compliance with DOE Order 5480.23, Nuclear Safety Analysis Reports) and DOE-STD-5502-94 (Hazard Baseline Documentation) were used as guidance.

- A fault-tree analysis was performed for accident scenarios that shows a high safety risk during the accident selection process. The accident consequence, frequency, and risk criteria are presented in Figures C.4-1 through C.4-8. Appendix C. 4 contains the fault trees for the DBAs and the accident scenarios are described in Section 5.5.

- Chemical doses, radiological doses for workers, co-located workers, and the general public at the site boundary were calculated for the unmitigated accident scenarios. Appendix C.5.3 describes the calculations and use of EPI-Code and HOTSPOT software. A summary of accident consequences is presented in Section 5.6.

No credit was taken for the secondary containment building in the unmitigated accident analysis. This approach maximizes the radiological doses and contaminant concentrations. However, for the MTU user sites, this PHA assumes a RCRA-permitted building will be provided for the MTU operation.

\subsection{Hazard Identification from HAZOP}

The process and operating hazards associated with the PO*WW*ER MTU were identified during a HAZOP analysis performed on July 10-12, 1995. Identified hazards were quantified and ranked using an integrated risk assessment which evaluated both the expected frequency of the deviation (hazard or accident) and the consequence. Appendix C.1 provides the results of the HAZOP analysis (see Attachment C.1-1) and details about the ranking and evaluation methods used. After each deviation was quantified according to these criteria, priority rankings were assigned to each deviation by combining the frequency rating with the highest consequence rating. Only two deviations received the highest overall risk ranking: (1) foaming or undetected high level in the evaporator resulting in carryover of liquid into the oxidizer heaters, which in turn could cause an explosion due to thermal stresses in the heaters; and (2) low/no process flow in the Econobator inlet line, which could create an explosive situation due to high propane concentration (propane was originally used as a halide scavenger). 
The HAZOP analysis identified 159 "action items" to be considered as possible mitigators for various hazards. These action items are enumerated in the right-hand column of Attachment C.1-1 ("Actions"). Table C.2-1 lists each action item in numerical order, along with the deviation it addressed, the priority of that deviation, a description of the action item, and a statement giving the resolution of the action item.

A number of the HAZOP analysis action items were related to liquid carryover from the evaporator or to the propane addition system, the two highest risk priority hazards identified during the HAZOP analysis. Liquid carryover from the evaporator was mitigated by adding redundant level and foam instrumentation and by modifying the design of the evaporator to the current multichambered design that adds two stages of demisting and a very circuitous flow path. The risk of the low/no Econobator inlet flow scenario was mitigated by deleting the propane addition and replacing it with ethanol, added as a liquid to the evaporator feed. The presence of a small concentration of ethanol, a flammable liquid, at a point in the process (the evaporator) where small concentrations of flammable liquids are normal, adds no additional hazards to the system. Problems with the propane addition caused a number of serious hazard scenarios during the HAZOP analysis, and deletion of the propane resolved 17 of the HAZOP analysis action items. Another source of major hazards was the quench system on the Econobator off gas; deletion of this system and replacement with the noncontact desuperheater resolved an additional 10 action items.

\subsection{Hazard Classification}

DOE-STD-1027-92 and DOE-EM-STD-5502-94 were used as guidance for the preliminary and final hazard classification of the PO*WW*ER MTU. Both the preliminary and final hazard classifications are based on a segmented system, as shown in Figure 4-1. The concept is allowed by DOE Order 5480.23 when MAR from one segment cannot interact with MAR from another segment. A detailed analysis of hazard classification is presented in Appendix B.

\section{Preliminary Hazard Classification}

The preliminary PO*WW*ER MTU hazard classification is "Radiological Facility," based on the total inventory considered MAR in the process. The MAR is described in detail in Appendix B.

\section{Final Hazard Classification}

The final hazard classification is based on the results of the unmitigated accident consequences presented in Appendix C.5. The results of the selected DBAs, based on the quantitative results of the unmitigated accident scenarios, indicate that the preliminary hazard classification was appropriate. Therefore, the PO*WW*ER MTU is classified as a "Radiological Facility" according to the classification scheme presented in DOE-EM-STD-5502-94. The unmitigated accident consequences at the site boundary are several orders of magnitude less than the guidelines, indicating that the MTU is a low-hazard facility.

\subsection{Accident Scenarios}

Accident analysis entails the formal quantification of a limited subset of accidents (i.e., DBAs). These accidents represent, as noted in DOE Order 5480.23, "a complete set of bounding conditions." The identification of DBAs for the PO*WW*ER MTU was based on the hazard evaluation ranking of the complete spectrum of facility accidents described in Appendix C.3.

Four possible accident scenarios were chosen for possible DBAs as a result of the hazard survey performed during the PHA. These scenarios were divided in "sub-scenarios" where appropriate. These scenarios and subscenarios were: 
1. Natural phenomenon

2. Ethanol fire

a. Major ethanol fire

b. Minor ethanol fire

3. Personnel injury from steam release

a. Steam fatality due to catastrophic steam release

b. Chronic steam release due to a slow leak that is not immediately apparent

4. Personnel injury from chemical exposure

a. Personnel injury from loss of containment of sulfuric acid

b. Personnel injury from loss of containment of sodium hydroxide

c. Personnel injury from chemical reaction of sodium hydroxide and sulfuric acid

A fault tree analysis was done for each of these scenarios to evaluate the probability of the occurrences. The fault tree analyses are shown in Appendix C.4. Based on the fault tree analyses, the only scenarios that needed to be considered in additional detail were those with a risk ranking of 3 or higher. This eliminated from further consideration all of the scenarios in Group 4, personnel injury from chemical exposure. The determination of overall risk rankings for the remaining scenarios is discussed in detail in Appendix C. 4 and the fault trees are presented in Figures C.4-1 through C.4-8. The highest overall risk ranking for any scenario is 2 , for a major ethanol fire. This therefore becomes the DBA for the facility.

\subsubsection{Design Basis Accident for the PO*WW*ER MTU}

The PO*WW*ER MTU DBA, which is considered bounding for all potential accidents, is the loss of containment on the 5-gal carboy of ethanol on the waste feed skid. The 5-gal carboy is assumed to be ruptured or spilled, and the spilled ethanol results in a concentration in the containment room at the lower explosive limit (LEL). An explosion, or rapidly expanding fire, is assumed to result in the loss of containment in the waste feed system and the evaporator. All waste contents of these units are then assumed to be involved in the ensuing fire/explosion.

The fire/explosion scenario involves the worker in the building containing the MTU, the nearest non-MTU worker on the site, and the off-site public. The MTU worker is assumed to reside in the building during the fire for 30 minutes, thus allowing time for rescue if the worker is not capable of self rescue. The nearest non-MTU worker and the offsite public member is assumed to reside at their location for the duration of the atmospheric plume passage.

\subsubsection{Design Basis Accident Scenarios}

For this process hazards analysis, three scenarios were selected on the basis of available site information, the EO treatability testing analytical data, and the PO*WW*ER MTU design waste acceptance criteria.

Worst Case: The concentration of contaminants of concern are double the concentrations found in the treatability studies. (There is no evidence that any of the waste streams identified for treatment with the PO*WW*ER MTU contain this level of organics or radionuclides). Uranium-238 and plutonium-239 are both present at $0.1 \mu \mathrm{Ci} / \mathrm{g}$. Hazardous concentrations are 8 weight percent isopropyl alcohol, 10 percent ammonium hydroxide, and 1.3 percent methylene chloride. 
Worst Likely Case: Based on the data from treatability testing, the most likely worst case would be uranium-238 at $5.6 \times 10^{-4} \mu \mathrm{Ci} / \mathrm{g}$ and plutonium-239 at $3.34 \times 10^{-6} \mu \mathrm{Ci} / \mathrm{g}$; hazardous constituents are 4.3 percent isopropyl alcohol, 5 percent ammonium hydroxide, and 1.3 percent methylene chloride.

Likely Low-Activity and Low-Hazardous Concentrations Case: Presently, this case represents the waste identified to be treated with the PO*WW*ER MTU. The basis is uranium-238 at $2.8 \times 10^{-4} \mu \mathrm{Ci} / \mathrm{g}$ and plutonium-239 at $2.38 \times 10^{-6} \mu \mathrm{Ci} / \mathrm{g}$; hazardous constituents are 4 percent isopropyl alcohol, 2.8 percent ammonium hydroxide, and 0.88 percent methylene chloride.

In each case, the maximum quantities of material used are those given in Appendix B.1.4.

\subsection{Accident Consequences}

Fire/explosion DBA consequences were assessed for each source-term scenario for the PO*WW*ER MTU, as described in Section 5.5. Concentrations and doses of hazardous constituents are presented in Appendix $A$ and summarized in Table 5-1 for the distances determined from the evaluation basis site characteristics. Additional consequences at several other distances are addressed in Appendix C.

The ethanol fire/explosion DBA analysis resulted in significant consequences to the PO*WW*ER MTU worker. High doses from radionuclides and hazardous chemical concentrations at levels greater than the immediately dangerous to life or health (IDLH) level were calculated.

The ethanol fire/explosion DBA analysis for the on-site nearest worker and the site boundary, where a member of the public resides, resulted in minimal impacts with very low dose levels from radionuclides and chemical concentrations several orders of magnitude less than the IDLH values.

The Guidance for the Preparation of MWT Process Hazards Analysis (DOE 1995b) document references Appendix A of DOE-STD-3009-94 for evaluation criteria for unmitigated accident consequences; however, Appendix A was never published. Vince Wahler* of the DOE-AL Nuclear Safety Division indicated that the criteria of interest in the unpublished document was that equipment that mitigates a site boundary dose to a member of the public in excess of $25 \mathrm{rem}$ committed effective dose equivalent should be designated as safety classification equipment (Wahler 1996). For chemicals, the Emergency Response Planning Guidelines (ERPG) III level is not exceeded at the site boundary, therefore the facility is classified as a low hazard. For chemicals without ERPGs, a similar criteria may be used, such as a facility is considered to be low hazard if the IDLH concentration is not exceeded at the site boundary. Using this guidance, the PO*WW*ER MTU is considered a low-hazard facility.

\footnotetext{
Per telephone conversation between R. L. Morris of Rust Geotech and Vince Wahler of DOE-AL Nuclear Safety Division on March 8, 1996 (Wahler 1996), the applicable guideline indicates a fence line dose to a member of the public in excess of 25 rem committed effective dose equivalent.
} 
Table 5-1. Radiological Dose and Hazardous Concentrations for the Fire DBA

\begin{tabular}{|c|c|c|c|c|}
\hline $\begin{array}{l}\text { Fire DBA } \\
\text { Event }\end{array}$ & Source Term & $\begin{array}{c}\text { PO*WW*ER } \\
\text { Worker }\end{array}$ & $\begin{array}{c}\text { Onsite Nearest } \\
\text { Worker } \\
(0.3 \mathrm{~km})\end{array}$ & $\begin{array}{l}\text { Site Boundary } \\
(2.8 \mathrm{~km})\end{array}$ \\
\hline \multirow{6}{*}{ Worst Case } & $100 \mathrm{nCi} / \mathrm{g} \mathrm{Pu}$ & 109 rem & 2.4 mrem & 0.046 mrem \\
\hline & $100 \mathrm{nCi} / \mathrm{g} \mathrm{U}$ & 26 rem & 0.87 mrem & 0.015 mrem \\
\hline & $10 \%$ wt. ammonia & $>$ IDLH & 110 ppm & $0.36 \mathrm{ppm}$ \\
\hline & $\begin{array}{l}8 \% \text { wt. isopropyl } \\
\text { alcohol }\end{array}$ & $>$ IDLH & $29 \mathrm{ppm}$ & $0.094 \mathrm{ppm}$ \\
\hline & $\begin{array}{c}1.3 \% \text { wt. } \\
\text { methylene chloride }\end{array}$ & $>$ IDLH & $5.5 \mathrm{ppm}$ & $0.018 \mathrm{ppm}$ \\
\hline & $7.5 \mathrm{~kg}$ ethanol & $>$ IDLH & $4.3 \mathrm{ppm}$ & 0.014 ppm \\
\hline \multirow{6}{*}{$\begin{array}{l}\text { Likely Worst } \\
\text { Case }\end{array}$} & $3.3 \times 10^{-6} \mu \mathrm{Ci} / \mathrm{g} \mathrm{Pu}$ & 36 mrem & $7 \times 10^{-4}$ mrem & $1.3 \times 10^{-5}$ mrem \\
\hline & $5.6 \times 10^{-4} \mu \mathrm{Ci} / \mathrm{g} U$ & $1.4 \mathrm{rem}$ & 0.043 mrem & $8.1 \times 10^{-4}$ mrem \\
\hline & $5 \%$ wt. ammonia & $>$ IDLH & 55 ppm & $0.18 \mathrm{ppm}$ \\
\hline & $\begin{array}{c}4.3 \% \text { wt. isopropyl } \\
\text { alcohol }\end{array}$ & $>$ IDLH & 15 ppm & $0.051 \mathrm{ppm}$ \\
\hline & $\begin{array}{l}1.3 \% \text { wt. } \\
\text { methylene chloride }\end{array}$ & $>$ IDLH & $5.5 \mathrm{ppm}$ & $0.018 \mathrm{ppm}$ \\
\hline & $7.5 \mathrm{~kg}$ ethanol & $>$ IDLH & $4.3 \mathrm{ppm}$ & $0.014 \mathrm{ppm}$ \\
\hline \multirow{6}{*}{$\begin{array}{l}\text { Likely Low- } \\
\text { Activity, Low- } \\
\text { Hazardous } \\
\text { Concentration }\end{array}$} & $\begin{array}{c}2.38 \times 10^{-6} \mu \mathrm{Ci} / \mathrm{g} \\
\mathrm{Pu}\end{array}$ & 26 mrem & $1.4 \times 10^{-3} \mathrm{mrem}$ & $2.7 \times 10^{-5}$ mrem \\
\hline & $2.8 \times 10^{-4} \mu \mathrm{Ci} / g \mathrm{U}$ & 728 mrem & $0.021 \mathrm{mrem}$ & $4.0 \times 10^{-4}$ mrem \\
\hline & $2.8 \%$ wt. Ammonia & $>$ IDLH & 31 ppm & $0.10 \mathrm{ppm}$ \\
\hline & $\begin{array}{c}4 \% \text { wt. isopropyl } \\
\text { alcohol }\end{array}$ & $>$ IDLH & 15 ppm & $0.051 \mathrm{ppm}$ \\
\hline & $\begin{array}{l}0.88 \% \text { wt. } \\
\text { methylene chloride }\end{array}$ & $>$ IDLH & $5.5 \mathrm{ppm}$ & $0.018 \mathrm{ppm}$ \\
\hline & $7.5 \mathrm{~kg}$ ethanol & $>$ IDLH & $4.3 \mathrm{ppm}$ & 0.014 ppm \\
\hline
\end{tabular}

'Unprotected worker: no credit is given for mitigators such as respirators or other emergency equipment available in the work area.

Key: $\begin{array}{ll}\mathrm{DBA} & =\text { design basis accident } \\ \mathrm{IDLH} & =\text { immediately dangerous to life or health } \\ \mathrm{kg} & =\text { kilogram(s) } \\ \mathrm{km} & =\text { kilometer(s) } \\ \mathrm{mrem} & =\text { milliroentgen(s) } \\ \mathrm{nCi} / \mathrm{g} & =\text { nanocuries per gram } \\ \mathrm{ppm} & =\text { parts per million } \\ \mathrm{Pu} & =\text { plutonium } \\ \mathrm{U} & =\text { uranium } \\ \mathrm{wt} \% & =\text { weight percent }\end{array}$




\subsection{Defense-In-Depth}

This section summarizes the defense-in-depth (i.e., prevention of uncontrolled hazardous or radioactive material releases) provided by the passive design features, engineered safety features (ESFs), and administrative controls for each type of hazard identified in the PO*WW*ER MTU PHA. ESFs and administrative controls that mitigate potential hazards were identified and evaluated during the HAZOP analysis. Attachment C.1-1, Table C.1-3, HAZOP analysis action items, contains a list of all potential hazards identified and their respective safeguards. Sections 3.0 and 4.0 also describe some of the major safety design features of the MTU.

Of the potential hazards identified during the HAZOP analysis, only two were given the highest combined overall hazard ranking. Those hazards are addressed in this section. The remaining hazards were evaluated for potential design improvements to lessen their severity and/or their frequency.

As presented in Section 5.3, the two most significant hazards identified during the HAZOP analysis of the PO*WW*ER MTU design were: (1) foaming or undetected high level in the evaporator resulting in carryover of liquid into the oxidizer heaters, which in turn could cause an explosion due to thermal stresses in the heaters; and (2) low/no process flow in the Econobator inlet line, which could create an explosive situation due to high propane concentration. Resolution of the first hazard was effected by adding redundant level and foam instrumentation and by modifying the design of the evaporator to the current multichambered design, which adds two stages of demisting and a very circuitous flow path. The second hazard was resolved by eliminating the propane addition (which was the detonation source) and replacing it with addition of ethanol as part of the evaporator feed. All other significant hazard initiators identified during the HAZOP analysis have been similarly mitigated.

The DBA for the PO*WW*ER MTU, an ethanol release and subsequent fire, results from human error not directly related to the operation of the process. Mitigation of such a hazard must depend on physical design elements (e.g., layout) and administrative controls rather than on process elements such as interlocks. The primary safeguard against catastrophic damage to the ethanol container is its location in the interior of the skid where the structural members will protect it from most major hazards. The design also minimizes the volume of ethanol and other hazardous compounds which will be kept on the skid at any time. Because ethanol is only needed by the process as a halide scavenger during treatment of highly halogenated waste streams, the SOPs will require that ethanol not be stored on the skid except when needed. The SOPs will also require that containers of ethanol and other hazardous chemicals be removed from the skid to a secure area before major maintenance is undertaken

The design employs a proven programmable logic control system with all critical instrumentation alarmed, including the capability for automatic shut-down of the MTU should critical operating parameters be exceeded. The SOP for the MTU and operators trained to the SOP will ensure the safe operation of the MTU. The instrumentation ensures that the information is available to the operator to safely operate the unit.

On the basis of the PHA, there are no structures, systems, or components (SSCs) of the PO*WW*ER MTU that are considered safety class SSCs. In accordance with the guidance provided in DOE-STD-3009-94 (Preparation Guide for U.S. Department of Energy Nonreactor Nuclear Facility Safety Analysis Reports), safety class SSCs are those which accident analyses indicates are needed to prevent accident consequences to the public from exceeding the evaluation guidelines. As presented in Appendix C.5, the unmitigated accident consequence results for the MTU are several orders of magnitude less than the guidelines at the site boundary; therefore, no SSCs are considered safety class SSCs. This 
identification of no safety class SSCs is consistent with DOE-STD-3009-94, which indicates that safety class SSCs normally will not be associated with Hazard Category 2 and 3 facilities due to their limited potential for off-site impact.

Safety significant SSCs are those SSCs not designated as safety class SSCs, but their preventive or mitigative function is a major contributor to defense-in-depth and/or worker safety as determined from the hazard analysis. According to the guidance provided in DOE-STD-3009-94, safety significant SSC designations based on worker safety are limited to those SSCs whose failure is estimated to result in a worker fatality or serious injuries to workers. The guidance also indicates that the distribution of the hazardous material inventory is a key consideration in designating safety significant SSCs (e.g., if the total hazardous material inventory is distributed over a hundred containers, the failure of any one container does not constitute a major uncontrolled hazardous material release). As presented in Section 5.4 and Appendix C.5, the PO*WW*ER MTU is a low-hazard Radiological Facility; this is a facility that does not meet or exceed the Hazard Category 3 threshold criteria of the potential for only significant localized consequences, and has hazards that present minor on-site and negligible off-site impacts to people and the environment. The risk of any injury to an MTU worker is low and the risk of serious injury or death from operation of the MTU is considered nonexistent. Therefore, based on the guidance and the design of the MTU, no SSCs are considered safety significant SSCs. 


\subsection{Conclusions and Recommendations}

On the basis of this PHA, the overall risk to any population group from operation of the PO*WW*ER MTU has been determined to be very low. The MTU is classified as a Radiological Facility (i.e., less than a Hazard Category 3 facility) with low hazards (i.e., minor on-site and negligible off-site impacts to people and the environment).

The unmitigated accident consequence results for the MTU are several orders of magnitude less than the guidelines at the site boundary; therefore, no SSCs are considered safety class SSCs. The risk of any injury to an MTU worker is low, and the risk of serious injury or death from operation of the MTU is considered nonexistent. Therefore, no SSCs are considered safety significant SSCs.

No credit was taken for the secondary containment building in the unmitigated accident analysis. This approach maximizes the radiological doses and contaminant concentrations. However, for the MTU user sites, this PHA assumes a RCRA-permitted building will be provided for the MTU operation.

No further action is required to reduce risks because changes to the design of the PO*WW*ER MTU were made concurrent with the hazard identification and analysis. Recommended actions have already resulted in design changes to reduce the risks to acceptable levels, incorporate cost-effective features, and improve design operability. The evaluation of the frequency or consequence of the risks and the mitigative features implemented in the PO*WW*ER MTU design are documented in Attachment C.1-1 and Table C.2-1 and summarized in Section 5.3. All hazards with initial risk rankings of 1 or 2 have been reduced to acceptable risk rankings of 3 or 4.

Based on the final hazard classification as a Radiological Facility and the guidance given for facilities with a final radiological classification (Section 6.3 of the Guidance for The Preparation of MWT Process Hazards Analysis [DOE 1995b]), this PHA is the only safety basis documentation necessary to support DOE authorization to operate the PO*WW*ER MTU at all user sites. No additional safety basis documentation (supplemental safety analysis and/or a full scope SAR) is required or recommended. 
This page intentionally blank 


\subsection{References}

Homann, S.G., 1994. HOTSPOT: Health Physics Codes for the PC, Hazards Control Department, Lawrence Livermore National Laboratory, University of California, Livermore, California.

California.

1988. EPIcode: Emergency Prediction Information, Homann Associates, Inc., Fremont,

Lange, N.A., Ph.D., 1961. Handbook of Chemistry, Tenth Addition, McGraw-Hill Book Company, Inc., New York, New York.

Liquid Air Corporation. "FLOAL Nitrogen Systems for the Chemical Process Industry," Tech Specs, Liquid Air Corporation, Walnut Creek, California.

Rust Engineering Company, 1995. PO*WW*ER Grand Junction, Colorado-Transportable Mixed-Waste Treatment Facility Process Hazard Analysis, 21-6565, Rust Engineering Company Process Technology Department, Clemson Technical Center, Anderson, South Carolina, July.

\section{U.S. Code of Federal Regulations:}

Title 29, "Labor."

Title 40, "Protection of Environment."

Title 49, "Transportation."

U.S. Department of Energy, 1996. PO*WW*ER Mobile Treatment Unit Design Report, GJPO-MWTP-20, prepared by Rust Geotech for the U.S. Department of Energy Grand Junction Projects Office, Grand Junction, Colorado, April.

1995a. Evaporative Oxidation Treatability Test Report, GJPO-MWTP-02, prepared by Rust Geotech for the U.S. Department of Energy Grand Junction Projects Office, Grand Junction, Colorado, January.

, 1995b. Guidance for the Preparation of MWT Process Hazards Analysis, prepared by the Treatment Selection Team for the Waste Management Division, U.S. Department of Energy Albuquerque Operations Office, Albuquerque, New Mexico, March.

1994. AL Mixed-Waste Treatment Plan, prepared by the Treatment Selection Team for the Waste Management Division, U.S. Department of Energy Albuquerque Operations Office, Albuquerque, New Mexico, March.

U.S. Department of Energy Orders DOE Order 5480.21, Unreviewed Safety Questions, 1991. DOE Order 5480.23, Nuclear Safety Analysis Reports, 1994. DOE Order 5480.31, Startup and Restart of Nuclear Facilities, 1993. 
U.S. Department of Energy Standards

DOE-STD-1020-92, Natural Phenomena Hazards Design and Evaluation Criteria for Department of Energy Facilities, 1992.

DOE-STD-1027-92, Hazard Categorization and Accident Analysis Techniques for Compliance with DOE Order 5480.23, Nuclear Safety Analysis Reports, 1992.

DOE-STD-3009-94, $\quad$ Preparation Guide for U.S. Department of Energy Nonreactor Nuclear Facility Safety Analysis Reports, 1994.

DOE-EM-STD-5502-94, Hazard Baseline Documentation, 1994.

U.S. Department of Health and Human Services, 1990. NIOSH Pocket Guide to Chemical Hazards, U.S. Department of Health and Human Services, Public Health Service, Centers for Disease Control, National Institute of Safety and Health, Washington, D.C., June.

Wahler, Vince, 1996. Personal communication between Vince Wahler, Nuclear Safety Division, U.S. Department of Energy Albuquerque Operations Office, Albuquerque, New Mexico, and R. L. Morris, Rust Geotech, Grand Junction, Colorado, March 8. 


\section{Appendix A}

\section{Evaluation Basis Site Characteristics}

A.1 Assumed Generic Site Characteristics

A.2 Assumed Attributes of Generic Secondary Containment

A.3 MTU Accidents as Initiators of External Accidents 
This page intentionally blank 


\section{Appendix A. Evaluation Basis Site Characteristics}

This appendix provides information on the methodology and assumptions used to develop the site characteristics. These characteristics are referred to as the evaluation basis site characteristics (EBSC). The EBSC were considered during the PO*WW*ER mobile treatment unit (MTU) Process Hazards Analysis (PHA). Because the unmitigated accident analysis is based on a generic set of site characteristics, simplified assumptions were used in the development of the characteristics to ensure conservatism. The design basis accident (DBA) selected as bounding for all potential PO*WW*ER MTU accidents was a fire/explosion from leakage of the ethanol drum in the waste feed system.

\section{A.1 Assumed Generic Site Characteristics}

The unmitigated accident analyses were conducted in a generic fashion to ensure that the consequences would be bounding for each site using the PO*WW*ER MTU. The distances to the nearest on-site facility and site boundary were determined based on information from Sandia National Laboratories, New Mexico (SNL/NM). SNL/NM has proposed a location for the MTU. Los Alamos National Laboratory (LANL) and Pantex (PTX) have not determined where the MTU will be located on site. Therefore, the analyses were conducted in a conservative manner to ensure that all sites could apply the results to their facilities. Table A.1-1 presents a summary of the EBSC considered during the unmitigated accident analyses.

Table A.1-1. Evaluation Basis Site Characteristics Summary (EBSC)

\begin{tabular}{|c|c|c|c|c|}
\hline \multicolumn{3}{|c|}{ Site Attribute } & SNLNM & EBSC \\
\hline \multicolumn{3}{|c|}{$\begin{array}{l}\text { Closest distance to site } \\
\text { boundary }\end{array}$} & $\begin{array}{c}2.8 \mathrm{~km} \\
(1.736 \mathrm{mi})\end{array}$ & $2.8 \mathrm{~km}$ \\
\hline \multicolumn{3}{|c|}{$\begin{array}{l}\text { Distance to nearest occupied } \\
\text { building or area }\end{array}$} & $\begin{array}{c}0.3 \mathrm{~km} \\
(0.186 \mathrm{mi})\end{array}$ & $0.3 \mathrm{~km}$ \\
\hline \multicolumn{3}{|c|}{$\begin{array}{l}\text { Distance from MTU to } \\
\text { MTU-exclusion-area boundary }\end{array}$} & Unknown & $\begin{array}{l}\text { Not needed for } \\
\text { analyses }\end{array}$ \\
\hline \multicolumn{3}{|c|}{ Pertinent meteorology } & Worst case & Worst case \\
\hline Key: & $\begin{array}{l}\mathrm{km} \\
\mathrm{mi} \\
\text { MTU } \\
\text { SNL/NM }\end{array}$ & $\begin{array}{l}=\text { kilometer(s) } \\
=\text { mile }(\mathbf{s}) \\
=\text { mobile treatm } \\
=\text { Sandia Nation }\end{array}$ & ratories, New N & \\
\hline
\end{tabular}

Note: EBSC distances are assumed, based on SNL/NM facility information. The worst case meteorology was used for the unmitigated accident analyses, which included a ground-level release with Category-F stability and a 1-meter-per-second wind speed.

The PO*WW*ER MTU is not expected to be significantly impacted by external events. Reactive and ignitable/flammable waste is stored at SNL/NM in skid-mounted storage buildings located approximately 100 feet to the northeast and to the northwest of Building 6920 , the proposed location of the PO*WW*ER MTU.

\section{A.2 Assumed Attributes of Generic Secondary Containment}

The unmitigated accident analyses do not take into account secondary containment. Therefore, radiological doses and hazardous contaminant concentrations are maximized in the analyses. 
Treatment, storage, and disposal facility regulations (40 CFR 264) include requirements for secondary containment for tanks and containers. These standards, or equivalent standards administered by a State, must be incorporated into a Resource Conservation and Recovery Act (RCRA) Part B permit for each facility. Thus, the Part B permit must interpret these standards and state the specific requirements. At a minimum, Part B permit requirements include secondary containment for vessels and containers containing free liquids. This secondary containment could be incorporated either in the skid or in the construction of the facility housing the PO*WW*ER MTU.

To be independent of the design of host facilities, the PO*WW*ER MTU skids have been designed to incorporate secondary containment for the vessels and piping. Secondary containment for spill control, in the form of a sump built into the bottom of the skids, is included in the PO*WW*ER MTU design. The floor of the skids will be constructed with grated material to allow spilled materials to fall through to the sump, where they will be contained.

It is the responsibility of the host site to ensure that the PO*WW*ER MTU is located in an area where external events would not impact the unit.

\section{A.3 MTU Accidents as Initiators of External Accidents}

The potential unmitigated accidents, developed from Appendix $\mathrm{C}$, are not considered to be potential initiators of further external accidents. The fire/explosion DBA would result in a rapidly expanding fire; however, it would not have enough force to create events at other facilities at the site. In addition, the mitigators for the fire/explosion DBA would likely stop a fire before it spread to other areas of the building where the PO*WW*ER MTU is located.

This PHA report did not considered the PO*WW*ER MTU accidents as initiators of external accidents. Because the MTU will be located at multiple sites, it would be prudent for site personnel to ensure that the MTU is not located next to areas containing highly reactive or flammable material and that an adequate fire suppression system be installed. 
Appendix B

\section{Materials at Risk}

B.1 Assumed Materials at Risk

B.2 Evaluation Basis Waste Characteristics

B.3 Assumed Cases for Process Hazards Analysis 
This page intentionally blank 


\section{Appendix B. Materials at Risk}

\section{B.1 Assumed Materials at Risk}

Characterization data for the mixed-waste streams proposed for treatment in the PO*WW*ER MTU is inadequate. To determine a maximum worst-case scenario for a Process Hazards Analysis of the MTU, available information, including data from characterization of the waste samples fed to the pilot-scale PO*WW*ER unit during treatability testing at the U.S. Department of Energy, Grand Junction Projects Office (DOE-GJPO), was reviewed. Data collected from the PO*WW*ER treatability test feed preparation analytical results for Sandia National Laboratories/New Mexico (SNL/NM), Los Alamos National Laboratory (LANL), and GJPO waste feed samples were used to determine the expected maximum worst-case scenario and a generic list of materials at risk (MAR).

It is assumed that the waste acceptance criteria for the PO*WW*ER MTU will be met by the host sites. The primary factors effecting MAR acceptability for PO*WW*ER MTU treatment are packaging and content characteristics.

\section{B.1.1 Packaging}

Waste shall be received in containers approved by the U.S. Department of Transportation (DOT) (i.e., authorized for the waste contained and chemically compatible with the wastes). The containers shall be 85-gallon (gal) overpack, 55-gal drums, or 30-gal drums that are free of surface defects, bulges, dents, or similar physical evidence of degradation, ice, snow, or mud. The containers shall have visible, legibly. printed, stenciled, or hand-written markings. The markings shall include all of the following:

- Name and address of the generator.

- Gross package weight.

- Waste-stream identification number.

- Major radionuclides present.

- Maximum radiation level on contact and at 1 meter in air.

- Proper DOT labels and markings.

- Resource Conservation and Recovery Act (RCRA) hazardous waste markings.

- No extraneous markings.

\section{B.1.2 Content Characteristics (waste acceptance criteria)}

According to 40 CFR 264.13 , the owner or operator of a waste treatment facility must obtain a detailed physical and chemical analysis of a representative sample of the waste, which must contain all of the information needed to treat, store, and/or dispose of the waste. The responsibility for confirming that wastes to be treated with the MTU conform to the waste acceptance criteria for the MTU belongs to the generators. 
The waste shall contain none of the following:

- Reactive wastes as defined in 40 CFR 261.23

- Wastes containing semivolatile organic contaminants which are immiscible in water

- Compounds having normal boiling points higher than $150^{\circ} \mathrm{C}$

- Toxic Substance Control Act wastes, including polychlorinated biphenyls (PCBs), due both to immiscibility and low volatility

- Phenolics

- Radioactivity levels greater than 100 nanocuries per gram (nCi/g)

In addition, no waste which exceeds the worst case concentrations for organic compounds given in Appendix B.3.1 should be accepted for treatment with the PO*WW*ER MTU without a thorough safety review.

\section{B.1.3 Waste Processing Limitations}

The PO*WW*ER MTU process is intended for treatment of volatile liquid waste, typically aqueous waste contaminated with less than 5 percent by weight RCRA-regulated volatile organics. Because the unit is an evaporator followed by a catalytic Econobator, any compounds that can be vaporized at or near the boiling point of water can be accepted as a feed material.

Because there are an infinite number of combinations of waste that the unit is capable of treating, the MAR was taken from a composite of the aqueous wastes treated by the pilot unit in the treatability studies performed at GJPO.

\section{B.1.4 Quantity of MARs}

For the basis of this analysis, it is assumed that the PO*WW*ER MTU will be installed in a RCRA-permitted building at the host site. Installing the MTU inside a building constitutes the secondary containment for the MAR. If a large building is chosen, it can be partitioned off to minimize the size of the process area. The minimum square footage required for the operation of the PO*WW*ER MTU is 1,296 square feet $\left(\mathrm{ft}^{2}\right)$, of which $276 \mathrm{ft}^{2}$, based on the primary skid layout as shown on Figure 4-1, needs to be in a radioactive material management area (RMMA).

\section{Segmentation of the PO*WW*ER MTU}

The PO*WW*ER MTU was divided into three primary segments: (1) waste feed tank/chemical addition skid; (2) evaporator skid; and (3) scrubber skid. The three segments for the MTU are independent systems, thus ensuring that an accident in one segment would not precipitate a release in the other segments of the MTU. The skids represent primary segments of the facility. The skids are bolted together and have their own independent spill control sumps. Figure 4-1 illustrates the PO*WW*ER MTU segmentation for hazard classification.

Segment 1: The waste feed tank skid is included in the total MAR inventory for the hazard classification. The waste feed tank skid will contain five drums of aqueous waste or 36.8 cubic feet $\left(\mathrm{ft}^{3}\right)$, a drum of 
50 percent sodium hydroxide (caustic) or $7.4 \mathrm{ft}^{3}$, a 5-gal carboy of 98 to 100 percent ethanol or $0.67 \mathrm{ft}^{3}$, and a 5-gal carboy of 98 percent sulfuric acid or $0.67 \mathrm{ft}^{3}$. Only one drum of waste will be opened at any time. The caustic, acid, and ethanol will be hard-piped to their respective metering pumps and to the waste feed tank. Unopened waste drums (i.e., those awaiting treatment) are excluded from the total MAR inventory as per DOE-STD-1027-92, which states that material contained in a DOT Type B shipping container, with or without overpack, may be excluded from assessment of a facility's radioactive inventory. Therefore the total maximum MAR for Segment 1 will be 3,091 pounds (lb) or 1,403 kilograms ( $\mathrm{kg}$ ) divided between the waste feed tank, weighing a total of $2,280 \mathrm{lb}$ or $1,035 \mathrm{~kg}$ at a specific gravity of 1.0 , the caustic drum weighing $702 \mathrm{lb}$ or $319 \mathrm{~kg}$ at a specific gravity of 1.53 , the acid carboy weighing 76 $\mathrm{lb}$ or $34 \mathrm{~kg}$ at a specific gravity of 1.83 , and the ethanol drum weighing $33 . \mathrm{lb}$ or $14.8 \mathrm{~kg}$ at a specific gravity of 0.79 .

Segment 2: The evaporator skid is included in the total MAR inventory for the hazard classification. The evaporator skid and associated heat exchanger, pump, and piping will contain up to $10.5 \mathrm{ft}^{3}$ of brine. In addition a collection drum for the brine will contain $7.4 \mathrm{ft}^{3}$. The total maximum MAR for Segment 2 will be $1,377 \mathrm{lb}$ or $625 \mathrm{~kg}$ divided between the brine collection drum weighing a total of $570 \mathrm{lb}$ or $259 \mathrm{~kg}$ at a specific gravity of 1.24 , and the contents of the evaporator system weighing a total of $807 \mathrm{lb}$ or $366 \mathrm{~kg}$ at a specific gravity of 1.24 .

Segment 3: The scrubber skid is included in the inventory for the hazard classification. The scrubber sump and associated piping contain approximately $8.0 \mathrm{ft}^{3}$ of scrubber liquor and the scrubber blowdown collection drum contains $7.4 \mathrm{ft}^{3}$ of scrubber blowdown liquor. The total maximum MAR for Segment 3 will be $1,012 \mathrm{lb}$ or $460 \mathrm{~kg}$ divided between the scrubber blowdown drum weighing a total of $486 \mathrm{lb}$ or $221 \mathrm{~kg}$ at a specific gravity of 1.06, and the scrubber sump weighing a total of $526 \mathrm{lb}$ or $239 \mathrm{~kg}$ at a specific gravity of 1.06 .

The residuals from processing include brine from the evaporator, scrubber liquor from the scrubber, and the vent gas. The brine from the evaporator will contain all of the radioactive components of the waste feed, excluding tritium, as well as any heavy metals or non-volatile organics. The scrubber liquor is essentially a 10 percent solution of sodium chloride (table salt) with a pH of 8 to 10 . Depending on the waste feed the vent gas will be a mixture of nitrogen, oxygen, carbon dioxide, water vapor, nitrogen and nitrous oxides, trace amounts of hydrochloric acid, and carbon monoxide. Tritiated water vapor would be present in the event that the waste feed contained tritium. The brine residual will be sealed in 55-gal drums for disposal as a low-level radioactive waste.

Table B.1.4-1 presents a summary of the maximum quantities of MAR allowed, or estimated, at each stage of the PO*WW*ER MTU process. 
Table B.1.4-1. Summary of Volume and Weight of Materials at Risk

\begin{tabular}{|c|c|c|c|c|}
\hline \multicolumn{2}{|c|}{ Segment } & \multirow{2}{*}{\begin{tabular}{|c|} 
Volume $\left(\mathrm{ft}^{3}\right)$ \\
36.8 \\
7.4 \\
0.67 \\
0.67
\end{tabular}} & \multirow{2}{*}{ 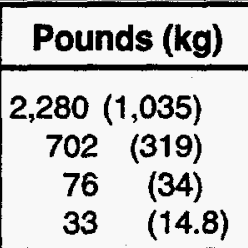 } & \multirow{2}{*}{\begin{tabular}{l}
\multicolumn{1}{c}{ Containment } \\
Sealed drums or tank \\
and two hard-piped \\
drums and a hard- \\
piped carboy
\end{tabular}} \\
\hline 1 & $\begin{array}{l}\text { Waste feed tank } \\
\text { Caustic drum } \\
\text { Acid carboy } \\
\text { Ethanol drum }\end{array}$ & & & \\
\hline 2 & $\begin{array}{l}\text { Evaporator } \\
\text { Brine drain drum }\end{array}$ & $\begin{array}{r}10.5 \\
7.4\end{array}$ & $\begin{array}{ll}807 & (366) \\
570 & (259)\end{array}$ & $\begin{array}{l}\text { Sealed evaporator } \\
\text { and piping and hard- } \\
\text { piped drum }\end{array}$ \\
\hline \multirow[t]{2}{*}{3} & $\begin{array}{l}\text { Scrubber sump } \\
\text { Blowdown drum }\end{array}$ & $\begin{array}{l}8.0 \\
7.4\end{array}$ & $\begin{array}{ll}526 & (239) \\
486 & (221)\end{array}$ & $\begin{array}{l}\text { Sealed scrubber and } \\
\text { two hard-piped drums }\end{array}$ \\
\hline & & Total & $5,480(2,488)$ & All normally sealed \\
\hline
\end{tabular}

\section{B.1.5 Hazard Classification}

Hazard classification as required by DOE Order 5480.23, Nuclear Safety Analysis Reports, is a two-fold system. The first element involves the initial, or preliminary assessment of the inventory of hazardous MAR and the estimate of the hazard classification. Once a hazards analysis has been performed the hazard classification can be finalized. The final classification is based on an "unmitigated release" of available material. For the purposes of hazard classification, "unmitigated" is meant to consider material quantity, form, location, dispersability, and interaction with available energy sources, but does not consider safety features (e.g., ventilation system, fire suppression), which will prevent or mitigate a release.

Figure B.1.5-1 presents a flow chart of the hazard classification process.

DOE Standards 1027-92 and 5502-94 were used as guidance for the preliminary and final hazard classification of the PO*WW*ER MTU. DOE-STD-1027-92 provides guidance on the requirements for the development of a safety analysis report based upon the hazard classification for nuclear facilities with Category 1 through Category 3 hazards. DOE-EM-STD-5502-94 provides additional guidance for further classification of facilities that are below the nuclear facility Category 3 hazard classification, and contains criteria for grouping environmental management facilities into nuclear, radiological, nonnuclear, or industrial categories. Only facilities that fall below the Category 3 classification threshold are exempt from the requirements of DOE Order 5480.23.

DOE-STD-1027-92 identifies a threshold for the total segmented inventory of a Category 3 nuclear facility. The quantity limits in Attachment 1 of DOE-STD-1027-92 were developed by taking the product of the airborne release fraction and effective dose equivalents from different pathways or sources (e.g., inhalation, ground contamination, and cloud shine).

To establish a hazard classification system based on inventories in DOE-STD-1027-92, DOE modified the U.S. Environmental Protection Agency (EPA) reportable quantities (RQs) for radionuclides defined in 40 CFR 302.4, Appendix B. The values for radionuclides represent levels of material that, if released, would produce less than 10-rem doses at 30 meters $(\mathrm{m})$ based on a 24-hour exposure. For the period of exposure, the DOE hazard classification models assume that persons are exposed for one day for inhalation and direct exposure, but that persons are exposed for longer periods through the ingestion 


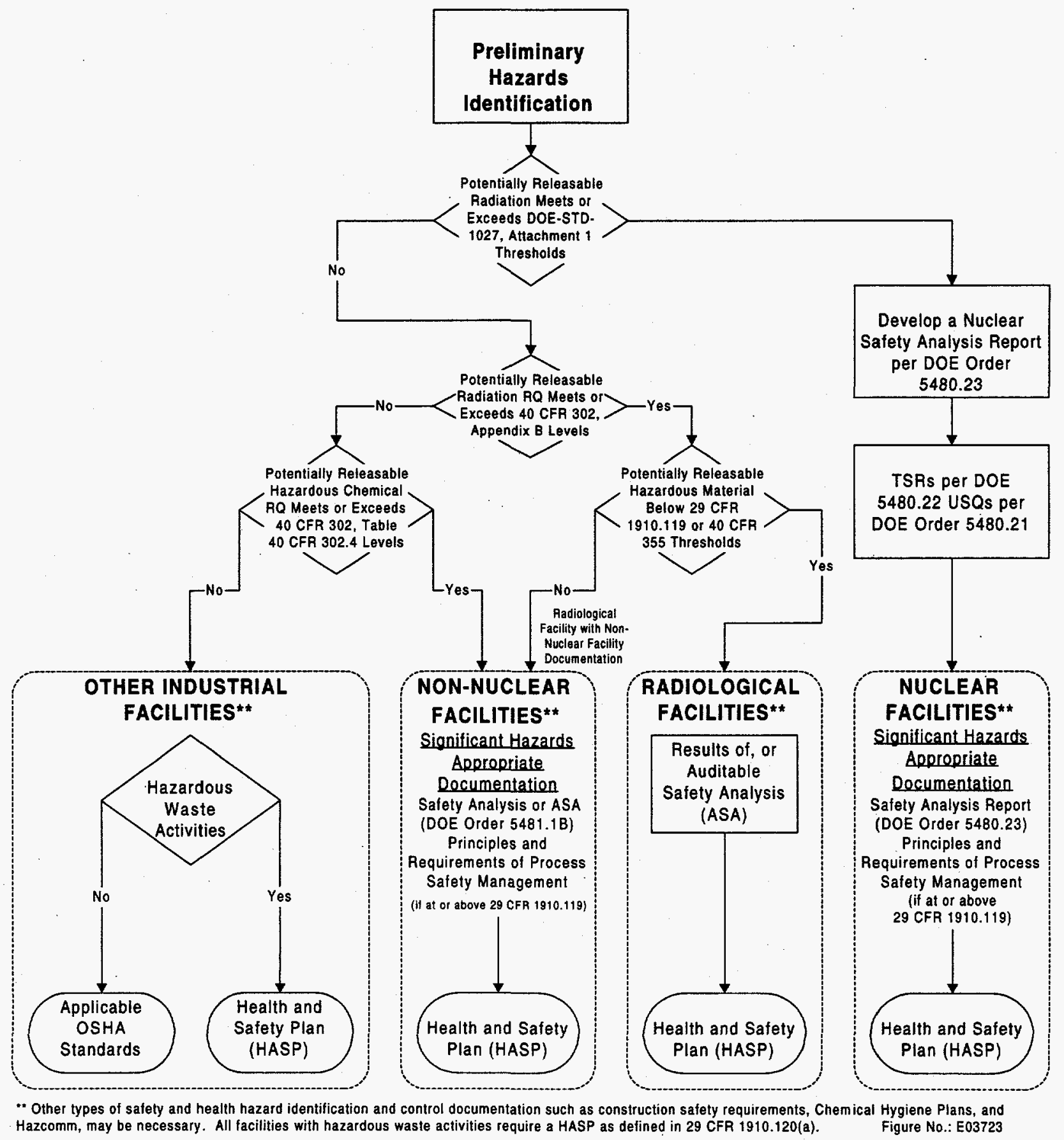

Figure B.1.5-1. Hazard Classification Process 
pathway in order to account for the slow movement of radionuclides in groundwater. For the sake of conservatism and simplicity, radioactive decay is not taken into account.

DOE-STD-1027-92 also modifies the hazardous release fractions used by the U.S. Nuclear Regulatory Commission (NRC) in NUREG-1140 and assumed a value of $10^{-3}$ for solids, powder, and liquid. DOE believes that the $10^{-3}$ value is a reasonably conservative approximation because it will be applied to an entire building without scenario-specific considerations. DOE recognizes that some accidents, particularly those involving powders and liquids, can produce much higher values, whereas accidents involving metals would normally produce slightly smaller release fractions. However, it is unlikely that any event will affect all material in a building, and high release phenomena such as explosions and pressurization will affect only a localized fraction of the material. Therefore, $10^{-3}$ is a reasonable average for hazard categorization purposes and was considered acceptable for hazard classification of the PO*WW*ER MTU.

The radionuclides of interest for the MTU are plutonium-239 (Pu-239) and uranium-238 (U-238) because these are the most likely radionuclides to be in the nontransuranic waste streams to be treated. $\mathrm{Pu}-239$ also is among the most limiting radionuclides in regard to concentration and inventory limits. Ethanol, methylene chloride, isopropyl alcohol, and ammonia were chosen as the worst case hazardous chemicals because of past processing knowledge. See Table B.2.2-1 for the evaluation basis waste characteristics.

\section{Preliminary Házard Classification}

The preliminary hazard classification of the PO*WW*ER MTU required identification of the MAR. The quantity of MAR for the MTU, as described in detail in Appendix B.1.4, provides the basis for the preliminary hazard classification. A preliminary hazard classification does not require assessment of specific accident scenarios; rather, it is based upon the total inventory considered at risk in the process.

DOE Order 5480.23 states that an analysis and categorization is to be performed on "processes, operations, or activities" and not necessarily whole facilities. For the purpose of categorizing hazards and estimating the MAR inventory for the PO*WW*ER MTU, the objective was to understand the possible hazards that could interact and cause harm to individuals or the environment. It is not desirable to estimate the potential consequences from an inventory of hazardous materials when facility features would preclude bringing this material together. Therefore, DOE Order 5480.23 allows the concept of facility segmentation, provided the MAR in one segment could not interact with MAR in other segments. The concept of independent facility segments was applied to the MTU where facility features preclude bringing MAR together or causing harmful MAR interaction from a common severe phenomenon.

\section{Facility Classification}

The most conservative estimate of MAR for the PO*WW*ER MTU hazard classification includes MAR from the evaporator, consisting of $626 \mathrm{~kg}$ divided between the brine collection drum weighing a total of $260 \mathrm{~kg}$ and the contents of the evaporator system weighing a total of $366 \mathrm{~kg}$. The likely worst-case concentration of contaminants assumed is $\mathrm{Pu}-239$ at $3.3 \times 10^{-6} \mu \mathrm{Ci} / \mathrm{g}$ and $\mathrm{U}-238$ at $5.6 \times 10^{-4} \mu \mathrm{Ci} / \mathrm{g}$. The evaporator will concentrate these radionuclides, and a concentration factor of 100 was assumed. This assumption results in a MAR of $2.09 \times 10^{-4} \mathrm{Ci}$ for Pu-239 and $3.5 \times 10^{-2} \mathrm{Ci}$ for U-238. Table A.1 of DOE-STD-1027-92 states that the Category 3 threshold of radionuclides is $0.52 \mathrm{Ci}$ for Pu-239 and $4.2 \mathrm{Ci}$ for U-238. Therefore, the MAR estimates for the PO*WW*ER MTU result in a hazard classification of less than a Category 3 facility.

DOE-EM-STD-5502-94 provides additional requirements for determining the hazard classification based on comparison of the MAR estimates to Table 302.4 of 40 CFR 302. The RQ for Pu-239 in Table 302.4 is 
0.01 Ci, and $0.1 \mathrm{Ci}$ for U-238. The PO*WW*ER MTU "likely worst case MAR" does not exceed the RQ value. However, since the exact contaminant concentrations and concentration factors in the evaporator are not known, it is considered prudent to classify the PO*WW*ER MTU as either a "Radiological Facility" or a "Radiological Facility with Non-Nuclear Documentation."

The determination of whether the PO*WW*ER MTU is a "Radiological Facility" or a "Radiological Facility with Non-Nuclear Documentation" is accomplished by comparing the estimates of the hazardous MAR to the RQ thresholds in 29 CFR 1910.119 and 40 CFR 355. The MAR estimates indicate that the chemicals listed in 29 CFR 1910.119 and 40 CFR 355 are not anticipated to be in the waste treated with the MTU. Therefore, the MTU is classified as a "Radiological Facility."

Although not part of the hazard classification for "Radiological Facilities," the RQs for hazardous substances in the waste are included in Table 302.4 of 40 CFR 302. A list of RQs of MAR from Table 302.4 of 40 CFR 302 are provided in Table B.1.5-2.

\section{Final Hazard Classification}

The final hazard classification of the PO*WW*ER MTU is based on the results of the unmitigated accident consequences presented in Appendix C.5. The results of the selected DBAs, based on the quantitative results of the unmitigated accident scenarios, indicate that the preliminary hazard classification was appropriate. The unmitigated consequences result in localized hazards without significant consequences for surrounding facilities or the off-site public. Therefore, the facility is classified as a "Radiological Facility" according the classification scheme presented in DOE-EM-STD-5502-94. The unmitigated accident consequences at the site boundary, as presented in Appendix C.5, are several orders of magnitude less than the guidelines, indicating that the MTU is a low-hazard facility.

Table B.1.5-2. Reportable Quantities for Hazardous Substances from 40 CFR 302

\begin{tabular}{|c|c|c|c|}
\hline Hazardous Substance & Regulatory Synonyms & $\mathbf{R Q}$ (lb) & $\mathbf{R Q}(\mathbf{k g})$ \\
\hline ammonia & none & 100 & 45.4 \\
\hline methylene chloride & methylene chloride & 1,000 & 454 \\
\hline ethanol & none & none & none \\
\hline isopropyl alcohol & none & none & none \\
\hline
\end{tabular}

\section{B.2 Evaluation Basis Waste Characteristics}

The concentration of the contaminants of concern has not been completely characterized for most of the wastes selected for treatment with the PO*WW*ER MTU. However, as a result of treatability testing with the pilot-scale PO*WW*ER unit, some waste characterization data exist. Initially, the PO*WW*ER MTU will be deployed to LANL, SNL/NM, or PTX. Characterization data from treatability tests performed with waste-stream samples from these three sites was used to set the limits for the hazardous and radioactive MAR that constitute the evaluation basis waste characteristics. 


\section{B.2.1 Primary Constituents Expected}

Data obtained from pilot-scale PO*WW*ER treatability testing of LANL waste-stream samples indicate the primary hazardous wastes, excluding RCRA heavy metals, are isopropyl alcohol, methylene chloride, and ammonium hydroxide. Table B.2.1-1 presents a summary of the properties of the hazardous constituents known to exist in the LANL waste streams. Also included is the ethanol added to the process as a chloride scavenger.

Table B.2.1-1. Summary of Hazardous Waste Properties

\begin{tabular}{||l|c|c|c|c|c|c||}
\hline Chemical & MW & $\begin{array}{c}\text { BP } \\
\left({ }^{\circ} \mathbf{F}\right)\end{array}$ & $\begin{array}{c}\text { LEL } \\
(\%)\end{array}$ & $\begin{array}{c}\text { IDLH } \\
\left(\mathbf{p p m}^{\mathbf{b}}\right)\end{array}$ & $\begin{array}{c}\text { VP } \\
(\mathbf{m m})\end{array}$ & $\begin{array}{c}\text { FP } \\
\left({ }^{\circ} \mathbf{F}\right)\end{array}$ \\
\hline $\begin{array}{l}(\%) \text { isopropyl } \\
\text { alcohol }\end{array}$ & 60 & 180 & 2 & 2,000 & 478 & -35 \\
\hline ammonia & 17 & -28 & 16 & 300 & $>1$ & NA \\
\hline methylene chloride & 85 & 104 & 12 & 2,300 & 350 & $\mathrm{c}$ \\
\hline ethanol & 46 & 173 & 3.3 & 3,300 & 44 & -173 \\
\hline
\end{tabular}

${ }^{a}$ All LEL values are in air.

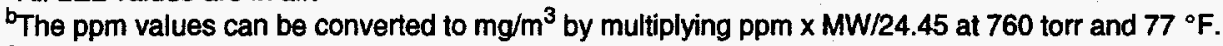

${ }^{\circ}$ Constituent is nearly nonflammable or nonflammable.

Key:

$\begin{array}{lll}\text { AIT }=\text { autoignition temperature } & \text { LEL }=\text { lower explosive limit } & \text { ppm }=\text { parts per million } \\ \text { atm = atmosphere } & \text { LFC }=\text { lowest feasible concentration } & \text { STEL }=\text { short-term exposure limit } \\ \text { BP }=\text { boiling point } & \mathrm{mm}=\text { millimeters } & \text { TWA }=\text { time weighted average } \\ \text { FP }=\text { flash point } & \mathrm{MW}=\text { molecular weight } & \text { VP }=\text { vapor pressure } \\ \text { IDLH }=\text { immediately dangerous to life or } & \mathrm{NA}=\text { not applicable } & \\ \text { health } & & \end{array}$

References: Handbook of Chemistry, Tenth Addition (Lange 1961), and NIOSH Pocket Guide to Chemical Hazards (U.S. Department of Health and Human Services 1990).

\section{B.2.2 Concentrations of Major Hazardous Constituents}

Limited data exist on the actual concentrations of hazardous constituents in the waste streams slated for treatment with the PO*WW*ER MTU. The Mixed-Waste Treatment Program, Evaporative Oxidation Treatability Test Report (DOE 1995a) documents the design considerations. The conclusion from the treatability testing is that the $\mathrm{PO} * \mathrm{WW} * \mathrm{ER}$ system is very adaptable to variations in volatile or radioactive concentrations in wastes. The limitation is the amount of heat given off in the catalyst bed which is a function of the type and concentration of any combustible organic present in the waste feed. With the exception of tritium, radionuclides and heavy metals have little effect on the operation.

Data from the pilot scale PO*WW*ER treatability testing of LANL waste samples indicate the maximum and minimum concentrations of the hazardous components as shown in Table B.2.2-1. 
Table B.2.2-1. Evaluation Basis Waste Characteristics

\begin{tabular}{|c|c|c|}
\hline \multirow[b]{2}{*}{ Chemical } & \multicolumn{2}{|c|}{ LANL } \\
\hline & $\begin{array}{c}\text { Minimum } \\
\text { (wt. \%) }\end{array}$ & $\begin{array}{c}\text { Maximum } \\
\text { (wt. \%) }\end{array}$ \\
\hline isopropyl alcohol & 0 & 4.3 \\
\hline ammonia & 0 & 5.1 \\
\hline methylene chloride & 0 & 1.5 \\
\hline
\end{tabular}

Note: The data indicate the range of values found.

Key: LANL $=$ Los Alamos National Laboratory

wt. $\%=$ weight percent

\section{B.2.3 Radioactive Contaminants}

The PO*WW*ER MTU will treat mixed waste with a radioactivity level less than $100 \mathrm{nCi} / \mathrm{g}$. With the exception of tritium and carbon-14, neither of which were present in any of the GJPO treatability test waste samples, the radioactivity is contained and concentrated in the evaporator and consequently has little effect on the process.

\section{B.3 Assumed Cases for Process Hazards Analysis}

For this process hazards analysis, three scenarios were selected on the basis of available site information, the EO treatability testing analytical data, and the PO*WW*ER MTU design waste acceptance criteria.

\section{B.3.1 Worst Case}

The first case depicts a worst case where the concentration of contaminants of concern are double the concentrations found in the treatability studies (with the exception of methylene chloride, which is included in this group at its solubility limit of 1.3 weight percent in water). On the basis of available information and recent testing, it is highly unlikely this scenario would ever be experienced. The basis is

Radioactivity: $\quad$ Uranium- 238 at $0.1 \mu \mathrm{Ci} / \mathrm{g}$

Plutonium-239 at $0.1 \mu \mathrm{Ci} / \mathrm{g}$.

Hazardous Constituents: Isopropyl alcohol at 8 weight percent.

Methylene chloride at 1.3 weight percent.

Ammonium hydroxide at 10 weight percent.

There is no evidence that any of the waste streams identified for treatment with the PO*WW*ER MTU contain this level of organics. The concentrations were derived by doubling the likely worst case data.

\section{B.3.2 Likely Worst Case}

Based on the data from treatability testing, the most likely worst case would be

Radioactivity: $\quad$ Uranium-238 at $5.6 \times 10^{-4} \mu \mathrm{Ci} / \mathrm{g}$

Plutonium-239 at $3.34 \times 10^{-6} \mu \mathrm{Ci} / \mathrm{g}$ 
Hazardous Constituents: Isopropyl alcohol at 4.3 weight percent.

Methylene chloride at 1.3 weight percent.

Ammonium hydroxide at 5 weight percent.

This case more realistically depicts the expected worst case.

\section{B.3.3 Likely Low-Activity and Low-Hazardous Concentrations}

Presently, this case represents the waste identified to be treated with the PO*WW*ER MTU. The basis is

Radioactivity:

Uranium-238 at $2.8 \times 10^{-4} \mu \mathrm{Ci} / \mathrm{g}$

Plutonium-239 at $2.38 \times 10^{-6} \mu \mathrm{Ci} / \mathrm{g}$.

Hazardous Constituents: Isopropyl alcohol at 4 weight percent.

Methylene chloride at 0.88 weight percent.

Ammonium hydroxide at 2.8 weight percent: 


\section{Appendix C}

\section{Process Hazards Analysis}

C.1 Hazards and Operability Analysis

C.2 HAZOP Analysis Action Item Tracking and Risk Reduction

C.3 Hazard Identification and Evaluation

C.4 Design Basis Accident Analysis Scenarios for Selected Accidents (Fault Trees)

C.5 Unmitigated Accident Consequences 
This page intentionally blank 


\section{Appendix C. Process Hazards Analysis}

The general process hazards analysis (PHA) process entails data evaluation to determine material at risk; hazards identification, evaluation, and resolution; accident scenario analysis; and consequence analysis. These steps build on one-another to arrive at a determination of the degree of hazards involved in the process being studied. This PHA followed the roadmap presented in Guidance for the Preparation of MWT Process Hazards Analysis (DOE 1995b).

\section{C.1 Hazards and Operability Analysis}

The hazards identification, evaluation, and resolution portion of this PHA chose the hazards and operability (HAZOP) analysis tool for its investigation of the hazards in a methodical meticulous manner. The HAZOP analysis process is a highly structured analysis and review of hazards associated with the operation of a chemical facility. The process is divided into a number of small sections, or nodes, selected from the piping and instrument diagrams (P\&IDs). A node is a specific piece of equipment or section of piping that normally only has one function. For instance, the waste transfer pump node includes the strainer and supply piping to the waste feed tank. The design intention for normal operation of each node is explained, and then a standard list of deviations from normal operation (e.g., high and/or low temperature, high and/or low pressure, high and/or low level, high and/or low/no flow) is applied to that node. Deviations which do not apply (e.g., high or low level for a line not containing any vessels) are removed from the list. Each remaining deviation is studied in terms of three factors:

1. All possible causes of that deviation (e.g., a plugged line for low/no flow). The causes are ranked according to their expected frequency.

2. The consequences to personnel and public safety, environmental contamination, financial loss, and general (miscellaneous) loss which will be realized if the deviation occurs. The consequences are quantified according to standard criteria.

3. Existing safeguards in the current design which tend to prevent the deviation from occurring.

The expected frequency of each deviation is combined with the consequence rating for the deviation in a "risk matrix" to generate an overall risk factor for the deviation. The risk factors are evaluated using standard decision criteria to determine whether the overall risk is high enough that the design must be modified to provide additional mitigation. Items requiring mitigation are then identified and responsibility for satisfactory completion of each item is assigned.

The HAZOP analysis of the PO*WW*ER MTU was performed on July 10-12, 1995. Attachment C.1-1 gives the results of the HAZOP analysis. The expected frequency of each deviation (column title "FC" in Table C.1-3) was quantified according to the guidelines listed in Table C.1-1.

Table C.1-1. Deviation Frequency Categories

\begin{tabular}{|c|l|}
\hline Category & \multicolumn{1}{|c|}{ Description } \\
\hline 1 & Not expected to occur during the lifetime of the MTU \\
\hline 2 & Expected to occur no more than once during the lifetime of the MTU \\
\hline 3 & Expected to occur several times during the lifetime of the MTU \\
\hline 4 & Expected to occur more than once in a year \\
\hline
\end{tabular}


Consequences were further divided into seven subcategories: Fire, Explosion, Environmental Damage, Toxic Release, Bodily Injury, Business Loss, and Operability Loss. The consequences were then quantified according to the guidelines listed in Table C.1-2; the results are given in the column headed "FXETIBO" (for Fire - EXplosion - Environmental Damage - Toxic Release - Bodily Injury - Business Loss - Operability Loss) in Attachment C.1-1.

Table C.1-2. Deviation Consequence Categories

\begin{tabular}{|c|c|}
\hline Category & Description \\
\hline \multicolumn{2}{|l|}{ Fire } \\
\hline 1 & No injury or health effects \\
\hline 2 & Minor injury or minor health effects \\
\hline 3 & Injury or moderate health effects \\
\hline 4 & Death or severe health effects \\
\hline \multicolumn{2}{|l|}{ Explosion } \\
\hline 1 & No injury or health effects \\
\hline 2 & Minor injury or minor health effects \\
\hline 3 & Injury or moderate health effects \\
\hline 4 & Death or severe health effects \\
\hline \multicolumn{2}{|c|}{ Environmental Damage } \\
\hline 1 & No environmental impact \\
\hline 2 & Minor environmental impact \\
\hline 3 & Moderate environmental impact \\
\hline 4 & Severe environmental impact \\
\hline \multicolumn{2}{|c|}{ Toxic Release } \\
\hline 1 & No injury or health effects \\
\hline 2 & Minor injury or minor health effects \\
\hline 3 & Injury or moderate health effects \\
\hline 4 & Death or severe health effects \\
\hline \multicolumn{2}{|c|}{ Bodily Injury } \\
\hline 1 & No injury or health effects \\
\hline 2 & Minor injury or minor health effects \\
\hline 3 & Injury or moderate health effects \\
\hline 4 & Death or severe health effects \\
\hline \multicolumn{2}{|c|}{ Business Loss } \\
\hline 1 & Less than $\$ 10,000$ \\
\hline 2 & Between $\$ 10,000$ and $\$ 100,000$ \\
\hline 3 & Between $\$ 100,000$ and $\$ 1,000,000$ \\
\hline 4 & More than $\$ 1,000,000$ \\
\hline
\end{tabular}


Table C.1-2 (continued). Deviation Consequence Categories

\begin{tabular}{||l|l|}
\hline Category & \multicolumn{1}{|c|}{ Description } \\
\hline Operability Loss & \multicolumn{2}{|c|}{} \\
\hline 1 & Less than 1 day \\
\hline 2 & Between 1 day and 1 week \\
\hline 3 & Between 1 week and 1 month \\
\hline 4 & More than 1 month \\
\hline
\end{tabular}

Once each deviation had been quantified according to these criteria it was possible to assign a priority ranking to each deviation by combining the frequency rating with the highest rating from the consequences. This gave a risk priority ranking for each deviation from 1 to 8 , with 8 being the highest.

Attachment C.1-1 lists the results of the HAZOP analysis and includes a description of each deviation studied, the cause(s) and consequence(s) of that deviation, and existing safeguards, as well as the information on the expected frequency and hazard rating of the deviation. The right-hand column of Attachment C.1-1 provides the number for each action item associated with mitigation of the deviation. 
This page intentionally blank 


\section{Attachment C.1-1}

Table C.1-3. HAZOP Analysis Action Items

Source: PO*WW*ER Transportable Mixed-Waste Treatment Facility Process Hazard Analysis, prepared by Rust Engineering Company, Process Technology Department, 1995. 
This page intentionally blank 
Table C.1-3. HAZOP Analysis Action Items

\begin{tabular}{|c|c|c|c|c|c|c|c|}
\hline $\begin{array}{l}\text { Item } \\
\text { Number }\end{array}$ & Deviation & Causes & $\begin{array}{l}\mathrm{f} \\
\mathrm{c}\end{array}$ & Consequences & FXETIBO & Safeguards & Actions \\
\hline
\end{tabular}

1.0 LINE - Waste Transfer to Waste Feed Tank (dwg: E03025-RAA-102-D)

1.1 High Flow

1.2 Low/Ho Flow

1.3 REVERSE FLOW

1.5 High Temperature

1.5 Low Temperature

1.6 High Pressure

1.8 LOW/HIGH CONCENTRATION

1.7 Low Pressure
None

4 Possible Maintenance Personnel

\section{closed Valve}

Clogged Suction Line

strainer Change out procedure 1 Waste spill not foll owed

Overpressure in Haste Tank

External fire

Reaction in Pipe

1 Line Rupture / Fire

1

No viable cause

High Temperature

clógged strainer

closed Valve
Line rupture

None

None
3313323 Pressure Release Valves on Tank Operating / Maintenance Training

3313323 Waste Sampling procedures (reaction possibility)

Fire Protection Systems

Hot Work Permit procedures

3313323 Fire protection systems

Pump selection (low discharge pressure) pressure)

002
003
001

002


(cont inued)

\begin{tabular}{|c|c|c|c|c|c|c|c|}
\hline $\begin{array}{l}\text { I tem } \\
\text { Number }\end{array}$ & Deviation & Causes & $\begin{array}{l}F \\
C\end{array}$ & Consequences & FXETIBO & Safeguards & Actions \\
\hline
\end{tabular}

1.0 LINE - Waste Transfer to Waste Feed Tank (continued)

1.9 CONTAMINATION

1.10 EXTERnaL LEAK
High suspended solids in waste 4

Flange gasket leak

over pressure (I tem 1.6)

corrosion

Filter Leak

Maintenance Procedures not

followed

$\begin{array}{ll}\text { External fire } & 1 \text { Waste spill } \\ \text { High Pressure } & 1 \\ \text { Corrosion } & 1 \\ \text { Drum Drop / External strike } & 1\end{array}$

Clogged strainer / pump,
(low/no flow) (I tem 1.2)

High Pressure (1 tem 1.6)

2 waste leak

$\ldots \ldots .1$ Waste sampling

3313323

1..1211 Operating / Maintenance procedures

1

2
004
005

006
3313323 PM procedures

Fire protection systems

Proper materials of construction

Proper general arrangement 


\begin{tabular}{|c|c|c|c|c|c|c|c|}
\hline $\begin{array}{l}\text { Item } \\
\text { Number }\end{array}$ & Deviation & Causes & $\begin{array}{l}F \\
C\end{array}$ & Consequences & FXETIBO & Safeguards & Actions \\
\hline
\end{tabular}

2.0 VESSEL - WASTE FEED TANK (dwg: E03025-RAA-102-D)

\subsection{LOW PRESSURE \\ 2.2 HIGH PRESSURE}

LOW TEMPERATURE

2.4 HIGH TEMPERATURE

2.5

LOW LEVEL

2.6 HIGH LEVEL

\section{External Fire}

Unexpected reaction

High pressure in the Haste

feed line from tank to

evaporator (1 tem 3.7)

HIGH PRESSURE (1 tem 2.2)

High temperature in the Haste feed line from tank to evaporator (1tem 3.5)

High temperature in the Waste Feed Return Line (Item 9.5)

Instrumentation failure

Operator error

Instrumentation failure
None

1 relief valve release

1 High pressure in the Waste feed line from tank to evaporator (I tem 3.7)

HIGH TEMPERATURE (I tem 2.4)

None

High temperature in the Waste Feed Return Line (I tem 9.5)

High temperature in the Waste feed line from tank to evaporator (I tem 3.5)

Relief valve relief

2 agitator / tank damage

2 Loss of evaporator feed

2 Liquid waste release to evaporator via line 23

Liquid waste release via vacuum breaker relief valve (Spill)

\section{....23 Vent to evaporator}

....... Relief valve

Fire protection systems

Properly designed tank

\section{Vent to evaporator}

Relief valve

Fire protection system

Properly designed tank

$\ldots .23$

....22 Low level interlock

009

.....11 Training

$\ldots .12$ 
(cont inued)

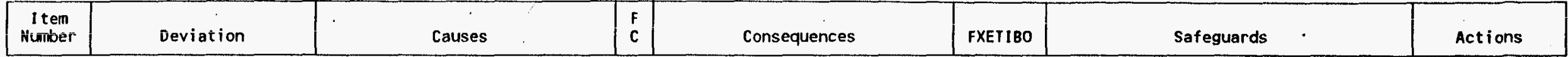

2.0 VESSEL - WASTE FEED TANK (cont inued)

\subsection{LOW/HIGH \\ CONCENTRATION}

2.8 CONTAMINATION

2.9 EXTERNAL LEAK
Too much solvent in waste tank 1 Agitator / pumping problems

Too high suspended solids in 1 pH out of specification

waste tank

Improper pH adjustment

(Inst./equip/operator

malfunction)

High RAD content

Presence of complex cyanides

3

Criticality Concerns

Cyanide complex requires

system shutdown

1. High/Low concentration in the Haste Feed Return Line (I tem

$19.9)$

High/LoH concentrotion in the Waste Feed Return Line (Item

$$
\text { 9.9) }
$$

High flow in the Sodium

Hydroxide Feed Line (I tem

21.1)

Low/no flow in the Sodium Hydroxide feed Line (I tem

21.2)

Contamination in the Waste feed Return Line (I tem 9.10)

Gasket failure

Agitator seal failure

Unexpected reaction in tank

Corrosion

Vacuum breaker leak

PSV leak

Contamination in the Waste Feed Return Line (Item 9.10)

Small waste spill

2 External Leak in the Waste Feed Return Line (Item 9.11)
....11 Waste sampling and feed procedures

.....11 Basket strainer

4444444

....12

......

3313323

System setup procedure (hydro testing)

PM procedures

016

Sampling and waste acceptance criteria

containment 
(cont inued)

\begin{tabular}{|c|c|c|c|c|c|c|c|}
\hline $\begin{array}{l}\text { It tem } \\
\text { Number }\end{array}$ & Deviation & Causes & $\begin{array}{l}F \\
C\end{array}$ & Consequences & FXETIBO & Safeguards & Actions \\
\hline
\end{tabular}

2.0 VESSEL - HASTE FEED TANK (cont inued)

2.10 EXTERNAL RUPTURE

$\begin{array}{ll}\text { Unexpected reaction } & 1 \text { Large waste spill } \\ \begin{array}{l}\text { Vessel Puncture (forklift, } \\ \text { etc.) }\end{array} & 1 \\ \text { External Fire } & 1\end{array}$

3.0 LINE - Waste feed line from tank to evaporator (dwg: E03025-RAA-102-D)

\begin{abstract}
3.1 High flow
\end{abstract}
3.2 Low/no flow

3.3 Reverse flow

3.4 Misdirected flow

3.5 High temperature

3.6 Low temperature
Metering pump mis-set

Pump failure

Plugged line

clogged Check valve

None

Metering pump (P-014) failure

Back flow of waste into proces

HIGH TEMPERATURE in the WASTE FEED TANK ( 1 tem 2.4)
2 High level in evaporator

3 Low Level in evaporator

3

4

\section{4}

Sampling / waste acceptance criteria

Fire protection systems

Limited access to area

Electrical Class 1, Div. 2
Air break in process water tank 
(cont inued)

\begin{tabular}{|c|c|c|c|c|c|c|c|}
\hline $\begin{array}{l}\text { I tem } \\
\text { Number }\end{array}$ & Deviation & Causes & $\begin{array}{l}F \\
C\end{array}$ & Consequences & FXETIBO & Safeguards & Actions \\
\hline
\end{tabular}

3.0 LINE - Waste feed (ine from tank to evaporator (cont inued)

3.7 High pressure

$$
\begin{aligned}
& \text { HIGH PRESSURE in the WASTE } \\
& \text { FEED TANK (I tem 2.2) } \\
& \text { Valve closed on metering pump } \\
& \text { discharge }
\end{aligned}
$$

\subsection{Low pressure}

\subsection{Low/High}

Concentration

$\begin{array}{lll}\text { High suspended solids } & 3 & \text { Line plug } \\ \text { High concentration of organics } & 3 & \text { Corrosion (leak) } \\ \text { Low pH } & 3 & \text { Process upset } \\ \text { High pH } & 4 & \end{array}$

3.10 Contamination

3.11 External Leak

3.12 External Rupture

\section{Corrosion}

Gasket failure

Pump seal failure

Erosion

\section{External Fire}

External strike
- Rupture (Spray)

HIGH PRESSURE in the WASTE FEED TANK (I tem 2.2)

None

None

1 Haste leak

1

1

1 Haste Spill
3313323

Standard Operating Procedures

...... Metering pumps internal PSV

027

028
029
-......

.....11 Waste feed Tank (Dampens waste

variation)

1.. 1211

$\ldots . .11$

Control systems

Feed strainer

$\cdots \cdots$

..22112 Preventive maintenance

Standard Operating Procedures . startup

3313323 Fire Protection Systems Material handling equipment selection

Containment 
(cont inued)

\begin{tabular}{|c|c|c|c|c|c|c|c|}
\hline $\begin{array}{l}\text { I tem } \\
\text { Number }\end{array}$ & Deviation & Causes & $\begin{array}{l}F \\
C\end{array}$ & Consequences & FXETI80 & Safeguards & Actions \\
\hline
\end{tabular}

4.0 HEAT_EXCHANGER - Evaporator Heater (dwg: E03025-RAA-102-D)

4.1 Shell leak (Steam)

Flange leak

Corrosion

Relief valve leak

Vacuum breaker leak

Steam control valve failure

High temperature in the Brine recirculation line $w /$ pump

(Item 6.5)

4.3 Low temperature

Loss of stean

Waste tank overflow

Low temperature in the Brine recirculation line w/ pump

(1tem 6.6)

None

4.5 Low pressure

4.7 High Level

4.4 High pressure

Steam trap failure
1 Steam Leak - Personnel injury

1

2

4

- Brine flashing in heater

- High temperature in the Brine recirculation line w/ pump (I tem 6.5)

2 Possible solidification of brine

High organics to oxidizer (vapor or liquid)

Possible aqueous liquid to $\quad 3433444$ oxidizer

Low temperature in the Brine recirculation line w/ pump (1 tem 6.6)

closed drain valve

clogged check valve
None

2 Loss of heating (see low temperature in evaporator)
030

Preventive maintenance

032

.......

.......

....12

.2 .2334

......

....... 
(cont inued)

\begin{tabular}{|c|c|c|c|c|c|c|c|}
\hline $\begin{array}{l}\text { I tem } \\
\text { Number }\end{array}$ & Deviation & Causes & $\begin{array}{l}F \\
C\end{array}$ & Consequences & FXETIBO & Safeguards & Actions \\
\hline
\end{tabular}

4.0 HEAT_EXCHANGER - Evaporator Heater (cont inued)

$4.8 \mathrm{High} / \mathrm{LOW}$

concentration

Low pH

High suspended solids

High/low concentration in the

Evaporator (1 tem 5.13)

High/Low concentration in the Brine recirculation line $w /$

pump (I tem 6.9)

4.9 Contamination

4.10 Tube leak (Haste)

Corrosion

Erosion

High level RAD in waste stream

4.11 Criticality (mis-sampling)
3 Corrosion

3 Erosion

Plugging

scaling (carbonate worst

scaling)

criticality

High/low concentration in the Evaporator (Item 5.13)

High/Low concentration in the Brine recirculation line $w /$ pump (I tem 6.9)

None

Contamination of stean system (Normal venting of inerts)

\author{
....24 pH meter in system \\ ....24 intine density meter \\ ...2223 SOP/PM \\ ....24 Sample RAD and maintain a RAD \\ batance
}

1344444

-......

- . . . .

.......

$\ldots 2224$ Conductivity on condensate

....11 Waste acceptance criteria

Grab samples of waste and brine

RAD monitoring 


\begin{tabular}{|c|c|c|c|c|c|c|c|}
\hline $\begin{array}{l}\text { Item } \\
\text { Number }\end{array}$ & Deviation & Causes & $\begin{array}{l}F \\
C\end{array}$ & Consequences & FXETIBO & Safeguards & Actions \\
\hline
\end{tabular}

5.0 REACTOR_V - Evaporator (dwg: E03025-RAA-102-D)

5.1 High flow

5.2 Low/no flow

5.3 Reverse flow

\section{Too much steam}

Too high organics in waste strean

Loss of back pressure

High flow in the Evaporator Vapor Discharge Line (I tem 10.1)

High concentration of contaminants in the Evaporator Vapor Discharge Line (1 tem 10.9)

Plugged system downstream of evaporator

Steam valve fail closed (normal failure mode)

Plugged mesh pads

Low/no flow in the Evaporator Vapor Discharge Line (I tem

10.2)
2 Water entrainment to oxidizer

2 RAD entrainment to oxidizer

Solvent entrainment to

2 oxidizer

- Loss of oxidizer heater control when upset stops.

High flow in the Evaporator Vapor Discharge Line (I tem 10.1)

High concentration of contaminants in the Evaporator Vapor Discharge Line (I tem 10.9)

High flow in the Packed-Bed Scrubber (I tem 15.1)

3 Overpressure of evaporator RAD release

2 Low flow in catalytic oxidizer causing explosion

1 Low/no flow in the Evaporator Vapor Discharge Line (I tem - 10.2)

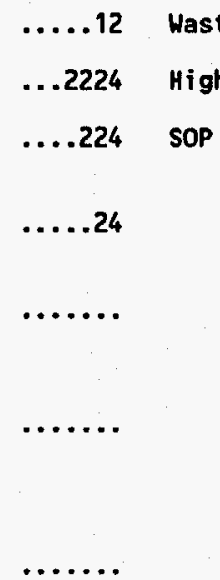

....12

$\ldots .224$ SOP

$\ldots .24$

.......

....

.23324

Preventive Maintenance 
(cont inued)

\begin{tabular}{|c|c|c|c|c|c|c|c|}
\hline $\begin{array}{l}\text { Item } \\
\text { Number }\end{array}$ & Deviation & Causes & $\begin{array}{l}\mathbf{F} \\
\mathbf{C}\end{array}$ & Consequences & FXETIBO & Safeguards & Actions \\
\hline
\end{tabular}

5.0 REACTOR_V - Evaporator (cont inued)

5.4 Misdirected flow

Pressure loss in propane .and/or oxidizer air lines

1 Contamination of propane and/or oxidizer air lines
(corrosion possibility)

5.5 High temperature

Externat fire

Criticality

High pressure (Item 5.7)

5.6 Low temperature

Loss of steam

5.7 High pressure

External fire

System blockage downstream of evaporator

High temperature (I tem 5.5)

None

Overflow from the Haste feed 1 Liquid to oxidizer heater -
tank tank

Instrumentation failure

Burn out heater

Foaming

Plugged waste feed line

Instrument failure
Rupture / relief (spill)

waste feed and system contamination

High pressure (1 tem 5.7)

- None

1 High temperature (I tem 5.5)
.....11 Flow meters in propane and oxidizer air lines

pressure indicator on propane

regulator

...2224 Fire protection equipment

039

.....11 RAD balance and monitoring

Relief vent

040

Fire protection system

$\ldots .24$ Spare heater

Positive slope to heater. evaporator low point in line.

Level indicators

Low low level interlock 


\begin{tabular}{|c|c|c|c|c|c|c|c|}
\hline $\begin{array}{l}\text { Item } \\
\text { Number }\end{array}$ & Deviation & Causes & $\begin{array}{l}F \\
C\end{array}$ & Consequences & FXET IBO & Safeguards & Actions \\
\hline
\end{tabular}

5.0 REACTOR_V - Evaporator (cont inued)

\section{$5.13 \mathrm{High/low}$} concentration

5.14 Contamination

5.15 External Leak

5.16 External Rupture

5.17 Criticality High/Low concentration in the
Evaporator Heater (I tem 4.8)

Low pH

High suspended solids

Gasket failure

External fire

High level RAD in waste stream (mis-sampling)
High/Low concentration in the
Evaporator Heater (Item 4.8 )

3 Corrosion

3 Erosion

Plugging

Scal ing (carbonate worst

scal ing)

Criticality

None

1 Waste leak

Waste spill

System shutdown

tration in the
er (Item 4.8)

....

$\ldots .24$

$\ldots .24$

$\ldots 2223$

....24

1344444

......

. $.22112 \quad P M$

SOP

3313323 Fire protection systems

relief valve

....11 Waste acceptance criteria

Grab samples of waste and brine

Monitoring of RAD
044

pH meter in system

Inl ine density meter

SOP/PM 
(cont inued)

\begin{tabular}{|c|c|c|c|c|c|c|c|}
\hline $\begin{array}{l}\text { I tem } \\
\text { Number }\end{array}$ & Deviation & Causes & $\begin{array}{l}F \\
C\end{array}$ & Consequences & FXETIBO & Safeguards & Actions \\
\hline
\end{tabular}

6.0 LINE_P - Brine recirculation line W/ pump (dwg: E03025-RAA-102-D)

\section{$6.1 \quad$ High flow}

6.2 Low/no flow

6.3 Reverse flow

6.4 Misdirected flow

6.5 High temperature

6.6 Low temperature
Plugged lines

Plugged tubes

Pump failure

Cavitation

Bumping in heat exchanger

High temperature (I tem 6.5)

Low pressure (I tem 6.8)

\section{None}

Open valve in line 7 . Waste spill

Sample valve in line 7 leaking

High temperature in the

Evaporator Heater (I tem 4.2)

Low/no flow (Item 6.2)

Low temperature in the

Evaporator Heater (I tem 4.3)

Precipitation of salts at solubility limit (1 tem 5.2)

3
None

2 Scaling in heater

$\ldots .2222$

Flow meter

045

2 Corrosion in 1 ines and tubes ....24

3 Loss of vapor flow to oxidizer .......

High temperature (I tem 6.5)

High temperature in the

Evaporator Heater (I tem 4.2)

- Low/no flow (Item 6.2)

Low temperature in the

Evaporator Heater (I tem 4.3)

- Erosion (leak)
Line 7 feeds brine concentration container 
(cont inued)

\begin{tabular}{|c|c|c|c|c|c|c|c|}
\hline $\begin{array}{l}\text { I tem } \\
\text { Number }\end{array}$ & Deviation & Causes & $\begin{array}{l}F \\
C\end{array}$ & Consequences & FXETIBO & Safeguards & Actions \\
\hline
\end{tabular}

6.0 LINE_P - Brine recirculation line w/ pump (continued)

6.7 High pressure

6.8 Low pressure

6.9 High/Low concentration

6.10 Contamination

6.11 External Leak

\section{Plugged tubes}

External Fire

Pump failure

low low evaporator level

Low/no flow (Item 6.2)

1

High/Low concentration in the High/Low concentration in the Evaporator Heater (1 tem 4.8)

Gasket leak

Pump seal leak

Valve packing leak

1 Rupture - line/tube

Corrosion

Erosion

Plugging

Scal ing (carbonate worst scal ing)

Criticality

None

1 Haste leak

1

1
...... Relief valve

Fire protection systems

Flow meter

Pressure indicator

Low Low alarm

Pressure differential across heater

pH meter in system

Inline density meter

$\ldots .24$ $\ldots .24$ balance

...2223 Waste acceptance criteria

$\ldots .24$

1344444

-......

. .22112 Preventive maintenance

standard Operating Procedures
047 
(cont inued)

\begin{tabular}{|c|c|c|c|c|c|c|c|}
\hline $\begin{array}{l}\text { I tem } \\
\text { Number }\end{array}$ & Deviation & Causes & $\begin{array}{l}F \\
C\end{array}$ & Consequences & FXETIBO & Safeguards & Actions \\
\hline
\end{tabular}

6.0 LINE_P - Brine recirculation line w/ pump (cont inued)

\begin{tabular}{|c|c|c|c|c|c|}
\hline 6.12 & External Rupture & External Fire & - Waste Spill & 3313323 & $\begin{array}{l}\text { Fire Protection Systems } \\
\text { Relief valve }\end{array}$ \\
\hline 6.13 & Criticality & High level RAD in waste stream & - System Shutdown & $\ldots \ldots 11$ & $\begin{array}{l}\text { Waste acceptance criteria } \\
\text { Grab samples of waste and brine } \\
\text { Monitoring of RAD }\end{array}$ \\
\hline
\end{tabular}

7.0 LINE - Brine Concentrate drain line (dwg: E03025-RAA-102-D)

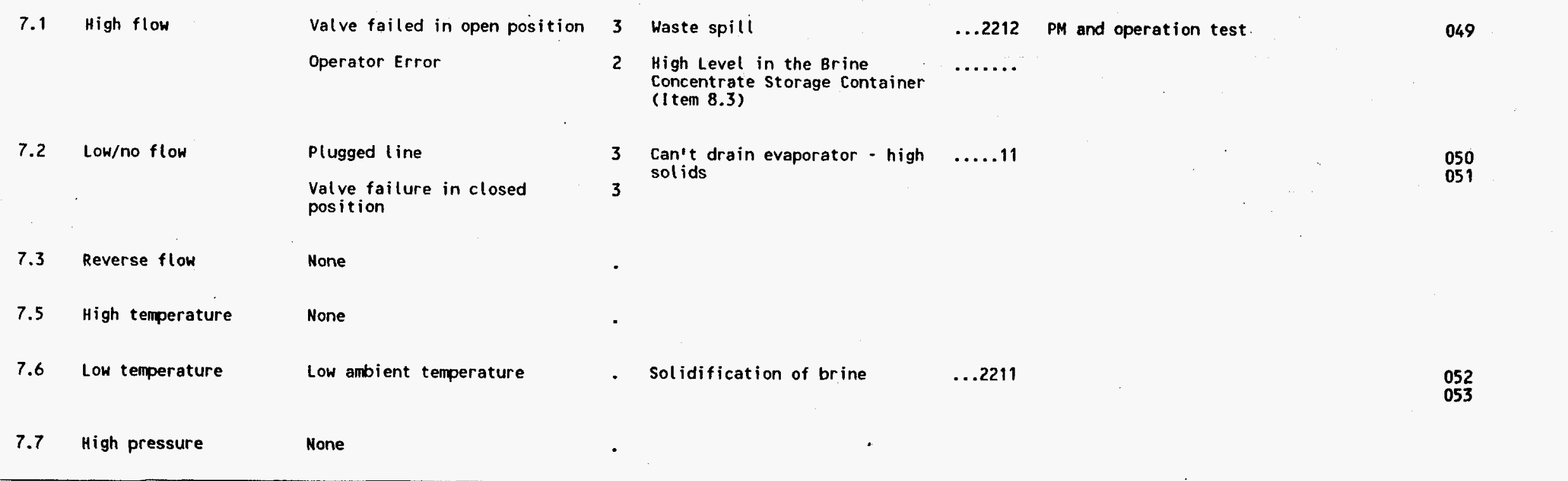


(cont inued)

\begin{tabular}{|c|c|c|c|c|c|c|c|}
\hline $\begin{array}{l}\text { I tem } \\
\text { Number }\end{array}$ & Deviation & Causes & $\begin{array}{l}\mathbf{F} \\
\mathbf{C}\end{array}$ & Consequences & FXETIBO & Safeguards & Actions \\
\hline
\end{tabular}

7.0 LINE - Brine Concentrate drain line (continued)

\begin{tabular}{|c|c|c|c|c|}
\hline 7.8 & Low pressure & None & - & \\
\hline 7.9 & $\begin{array}{l}\text { High/low } \\
\text { concentration }\end{array}$ & Mone & - & \\
\hline 7.10 & Contamination & Mone & - & \\
\hline 7.11 & External Leak & Valve packing leak & - & \\
\hline 7.12 & External Rupture & $\begin{array}{l}\text { Hose not in drum - operator } \\
\text { error }\end{array}$ & 1 & Waste spill \\
\hline 7.14 & Criticality & None & . & \\
\hline
\end{tabular}

8.0 VESSEL - Brine Concentrate Storage Container (dwg: E03025-RAA-102-D)

\begin{tabular}{|c|c|c|c|}
\hline 8.1 & High Temperature & None & - \\
\hline 8.2 & Low Temperature & None & - \\
\hline \multirow[t]{2}{*}{8.3} & High Level & $\begin{array}{l}\text { High flow in the Brine } \\
\text { Concentrate drain line (1 tem } \\
7.1)\end{array}$ & - $\quad$ Spill \\
\hline & & No level indication & . \\
\hline 8.4 & Low Level & None & . \\
\hline 8.5 & Contamination & None & . \\
\hline
\end{tabular}

\section{$\ldots 2212$ SOP \\ Operator hiring and training}

7.14 Criticality None 
(cont inued)

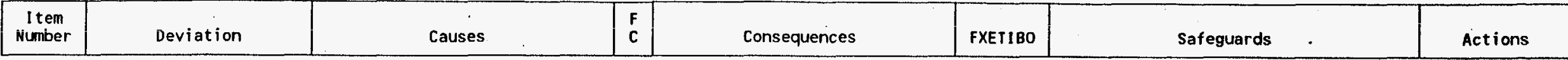

8.0 VESSEL - Brine Concentrate Storage Container (continued)

8.6 Leak

8.7 Rupture

$9.1 \quad$ High flow

9.2 Low/no flow

9.3 Reverse flow

9.5 High temperature

9.6 Low temperature

9.7 High pressure
Bad Drum

Static explosion

Dropped drum
2 Waste leak

Leak in the Scubber Bl owdown Storage Container (I tem 19.6)

1 Explosion
2 Haste Spil
. .2212 QA/QC on drum supply

Containment

3323324 SOP

..32214 Training

Pre-dump sample
056
057

058

059

9.0 LINE - Waste feed Return Line (dwg: E03025-RAA-102-D)

None

Valve closed

2 Loss of feed to evaporator

....11 SOP

Orfice plugged

3 Pump damage

....11 Prevent ive Maintenance

Pump failure

3 Loss of pH control (Corrosion)

....11

suction clogged to pump

None

HIGH TEMPERATURE in the WASTE FEED TANK (I tem 2.4)

HIGH TEMPERATURE in the WASTE FEED TANK (I tem 2.4)

Relief valve release

$\ldots .23$

None

Valve closed

1 Loss of pH control

$\ldots \ldots 11$ sop 


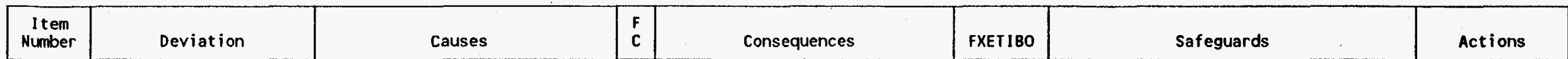

9.0 LINE - Haste Feed Return Line (continued)

9.8 Low pressure

Pump Failure

9.9 High/Low

concentration

9.10 Contamination

9.11 External Leak

9.12 External Rupture

waste tank waste tank
2 Loss of $\mathrm{pH}$ control

Low or no feed to evaporator

LOW/HIGH CONCENTRATION in the - LOW/HIGH CONCENTRATION in the WASTE FEED TANK (I tem 2.7)

Too much solvent in waste tank 1

Too high suspended solids in

Improper pH adjustment

(Inst./equip./operator error)

High RAD content

Presence of complex cyanides

CONTAMINATION in the WASTE FEED TANK (1 tem 2.8)

Too much solvent in waste tank 1

Too high suspended solids in

Improper $\mathrm{pH}$ adjustment

Presence of complex cyanides WASTE FEED TANK (I tem 2.7)

\section{Agitator/pumping problems}

1 pH out of specification

Criticality concerns

Cyanide complex requires system shutdown

CONTAMINATION in the WASTE FEED TANK (I tem 2.8)

Agi tator/pumping problems

$\mathrm{pH}$ out of specification

Cyanide complex requiring

system shutdown

.....11 Instrumentation - pump motor failure

....11 indicator

Pressure guage

Waste sampling and feed procedures

$\ldots \ldots 11$

$\ldots . .11$

4444444

....12

EXIERNAL LEAK in the WASTE

FEED TANK (I tem 2.9)

1
Waste sampling and feed procectures

Basket strainer $\ldots .11$

.....11

$\ldots \ldots 12$

No consequences of interest 


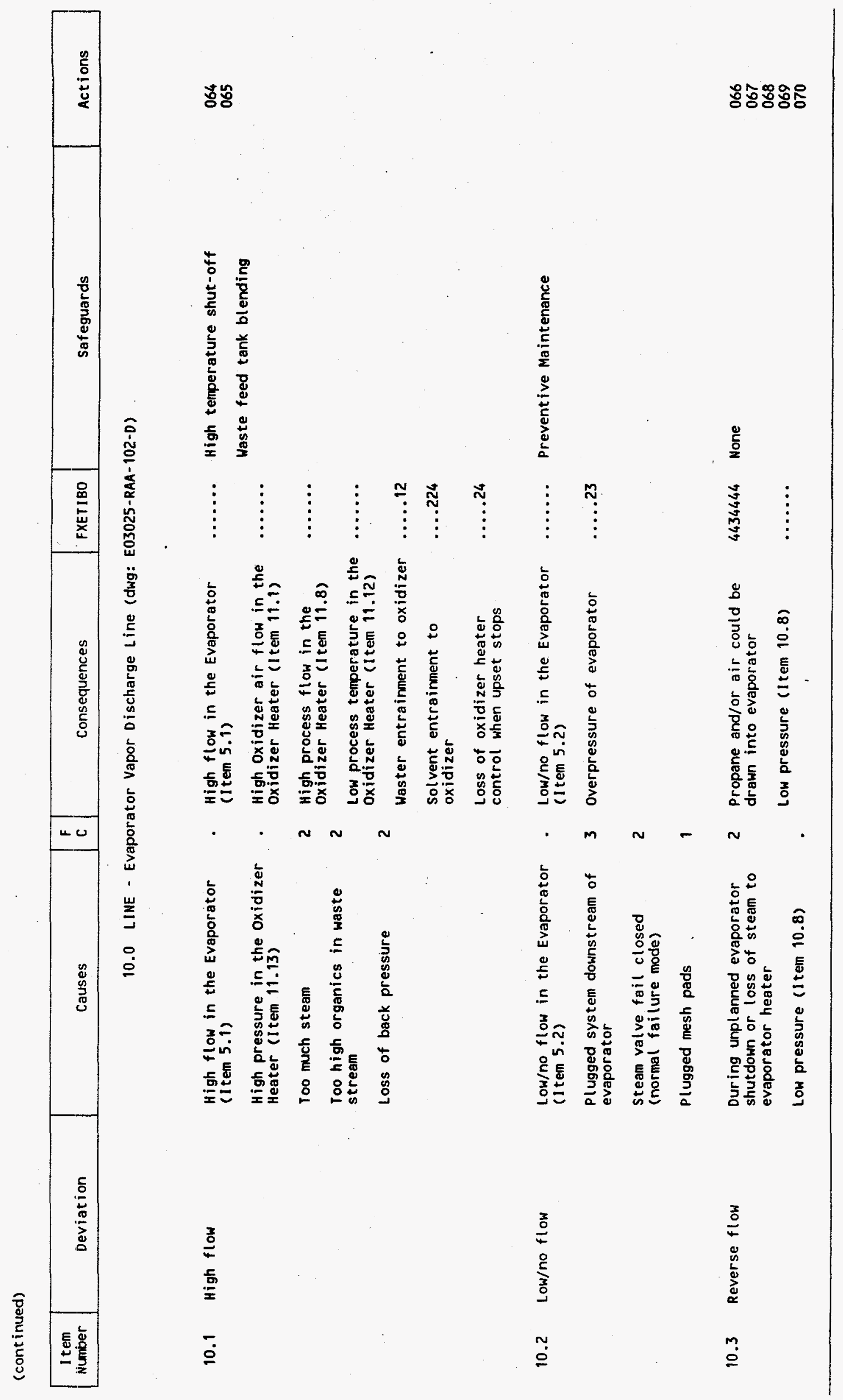


(cont inued)

\begin{tabular}{|c|c|c|c|c|c|c|c|}
\hline $\begin{array}{l}\text { I tem } \\
\text { Number }\end{array}$ & Deviation & Causes & $\begin{array}{l}F \\
C\end{array}$ & Consequences & FXETIBO & Safeguards & Actions \\
\hline
\end{tabular}

10.0 LINE - Evaporator Vapor Discharge Line (continued)

10.4 Misdirected flow

Propane line loss of pressure oxidizer air loss of pressure

Condensation in vapor line

Internal fire during unplanned 1 shutdown

Plugged line downstream from oxidizer heater

Ambient heat loss

Excessive liquid entrainment / 3 Foaming

Valve failure on warmup air (if relocated)

Line / System plug

steam fail open

Warmup air valve fail open
Corrosion in propane line and air line

Instrument damage $\ldots .12$

....12

Good piping practice (tie-in above

vapor (ine)

\section{4}

4444444

Propane backflow into evaporator (explosion in evaporator)

4 Condensation causing heater / catalyst damage

RAD contamination in heater / ...2223 catalyst

\section{System plug}

High concentration of contaminants (Item 10.9)

10.7 High pressure

Reverse flow (Item 10.3)
Evaporator PSV release

2 
(cont inued)

\begin{tabular}{|c|c|c|c|c|c|c|c|}
\hline $\begin{array}{l}\text { Iten } \\
\text { Number }\end{array}$ & Deviation & Causes & $\begin{array}{l}\mathbf{F} \\
\mathbf{C}\end{array}$ & Consequences & FXETIBO & Safeguards & Actions \\
\hline
\end{tabular}

10.0 LINE - Evaporator Vapor Discharge Line (continued)

10.9 High concentration of Low temperature (Item 10.6) contaminants

High solvent in waste feed

High flow in the Evaporator (1tem 5.1)

Large increases in waste feed.

rate

10.10 External Leak

Corrosion

Flange / gasket leak

1 Leak of vapor

High flow in the Evaporator(Solvent) (I tem 5.1)

Possible flamable mixture to heater

.333334

Waste blending in waste tank

080

082

$\ldots .2222$

sop
10.11 External Rupture

Internal fire / detonation

1 Vapor release

Design standards

4444444 PM

Design Standards

11.0 FURNACE - Oxidizer Heater (dwg: E03025-RAA-102-D)

11.1 High Oxidizer air High flow in the Evaporator flow

Vapor Discharge Line (Itern

10.1)

Waste entrainment to oxidizer

Solvent entrainment to

$\ldots .12$

$\ldots .224$

High temperature shut-off

Harmup air valve fail open oxidizers

FCV-032-6 driven or fails open, Loss of oxidizer heater

$\ldots .24$
Waste feed tank blending 
(cont inued)

\begin{tabular}{|c|c|c|c|c|c|c|c|}
\hline $\begin{array}{l}\text { I tem } \\
\text { Number }\end{array}$ & Deviation & Causes & C & Consequences & FXETIBO & Safeguards & Actions \\
\hline
\end{tabular}

11.0 FURNACE - Oxidizer Heater (continued)

11.8 High process flow

\section{High flow in the Evaporator Vapor Discharge Line (I tem 10.1) \\ Warmup air valve fails open}

Valve FCV-032-6 driven or fails open

High propane flow due to propane valve fails open

High flow in the oxidized Discharge Line (1tem 12.1)

High Flow in the Catalytic Oxidizer (Item 13.1)

High flow in the Discharge

line from oxidizer to scrubber

(Item 14.1)
Incomplete reaction

Explosive mixture sent to heater

- High flow in the oxidized

High flow in the Oxidized
Discharge Line (Item 12.1)

High Flow in the Catalytic

Oxidizer (I tem 13.1)

High flow in the Discharge

line from oxidizer to scrubber (Item 14.1) $\ldots \ldots 11$

083

4434444

084 
(cont inued)

\begin{tabular}{|c|c|c|c|c|c|c|c|}
\hline $\begin{array}{l}\text { I tem } \\
\text { Number }\end{array}$ & Deviation & Causes & $\begin{array}{l}F \\
C\end{array}$ & Consequences & FXETIBO & Safeguards & Actions \\
\hline
\end{tabular}

11.0 FURNACE - Oxidizer Heater (continued)

11.9 Low/no process flow

Plugged lines

Low vapor flow

Low propane flow

Low air flow

High process temperature (1tem 11.11)

Low pressure (I tem 11.14)

Low/no $f$ low in the oxidized Discharge Line (Item 12.2)

Low flow in the Catalytic oxidizer (Item 13.2)

High pressure in the Catalytic oxidizer (Item 13.7)

11.10 Misdirected process None flow

11.11 High process temperature
Low/no process flow (I tem 11.9)

Runaway heater

High temperature in the oxidized Discharge Line (Item 12.5)
3 Detonation

4 Heater damage

3 High process temperature (I tem 11.11)

Low pressure (I tem 11.14)

Low/no flow in the Oxidized Discharge Line (Item 12.2)

- Low Flow in the Catalytic

oxidizer (Item 13.2)

High pressure in the Catalytic .......

Oxidizer (Item 13.7)
4433444

(High

emp sensors, etc.)
- Low/no process flow (Item 11.98

2 Heater damage and Catalytic oxidizer damage

High temperature in the Oxidized Discharge Line (Iten 12.5)
Internal Heater safeties

$\mathrm{High}$ temp sensor at oxidizer 


\begin{tabular}{|c|c|c|c|c|c|c|c|}
\hline $\begin{array}{l}\text { I tem } \\
\text { Number }\end{array}$ & Deviation & Causes & $\begin{array}{l}F \\
C\end{array}$ & Consequences & FХЕTIBO & Safeguards & Actions \\
\hline
\end{tabular}

11.0 FURNACE - Oxidizer Heater (cont inued)

11.12 Low process temperature

11.13 High pressure

11.14 Low pressure
Heater failure

Control system failure

High flow in the Evaporator

Vapor D ischarge Line (I tem

10.1)

Low temperature in the

oxidized Discharge Line (Item

12.6)

Plugged lines downstream of

heater

Liquid stream entering heater

Tube leak or rupture (I tem

11.15)

2 Incomplete reaction

2 Low temperature in the

Oxidized Discharge Line (Item 12.6)
....11 Low Low interlock cuts feed

089 -......
3 Heater damage $\quad \ldots .22$

Gasket failure (Waste vapor $3 . .3323$

090
091

Low/no process flow (Item 11.9)

Low pressure in the oxidized Discharge Line (Item 12.8)

Low pressure in the Catalytic Oxidizer (Item 13.8)
High flow in the Evaporator Vapor Discharge Line (I tem 10.1)

Tube leak or rupture (1 tem 11.15)

- Low/no process flow (Item 11.9)

Low pressure in the Oxidized Discharge Line (Item 12.8)

- Low pressure in the Catalytic Oxidizer (Item 13.8) 
(cont inued)

\begin{tabular}{|c|c|c|c|c|c|c|c|}
\hline $\begin{array}{l}\text { I tem } \\
\text { Number }\end{array}$ & Deviation & Causes & $\begin{array}{l}F \\
C\end{array}$ & Consequences & FXETIBO & Safeguards & Actions' \\
\hline
\end{tabular}

11.0 FURNACE - Oxidizer Heater (continued)

11.15 Tube leak or rupture

High pressure (Item 11.13)

Detonation

Corrosion

External Leak in the Catalytic

Oxidizer (Item 13.11)

\section{3..3323 SOP \\ 4433444 Design standards}

PM

PSV - high pressure
092

Oxidizer (Item 13.11)

12.0 LINE - Oxidized Heater and Oxidizer Discharge Line to Quench (dwg: E03025-RAA-102-D)

$12.1 \quad$ High flow

12.2 Low/no flow

High process flow in the Oxidizer Heater (1 tem 11.8) Warmup air valve fails open Valve FCV-032-6 driven or fails

High propane flow due to propane valve failing open

Low/no process flow in the Oxidizer Heater (I tem 11.9)

Plugged lines

Low vapor flow

Low propane

Low air flow

None
High process flow in the

oxidizer Heater (Item 11.8)

1 Incomplete reaction

9 Explosive mixture sent to heater

Low/no process flow in the Oxidizer Heater (I tem 11.9)

3 Detonation

Heater damage $\quad \ldots \ldots 22$

3

4
4433444

....11

4434444
Heater internal safety devices (high 
(cont inued)

\begin{tabular}{|c|c|c|c|c|c|c|c|}
\hline $\begin{array}{l}\text { I tem } \\
\text { Number }\end{array}$ & Deviation & Causes & $\begin{array}{l}F \\
C\end{array}$ & Consequences & FXETIBO & Safeguards & Actions \\
\hline
\end{tabular}

12.0 LINE - Oxidized Heater and Oxidizer Discharge Line to Quench (cont inued)

12.5 High temperature High process temperature in
the Oxidizer Heater (Item 11.11)

Runaway heater

12.6 Low temperature

12.7 High pressure

Low pressure

12.9 High concentration of contaminants

12.10 External Leak

12.11 External Rupture Oxidizer (Item 13.7)

Plugged lines downstream of heater Heater (1 tem 11.14) failure

Internal Detonation Low process temperature in the
Oxidizer Heater (Item 11.12 )

Heater failure

Control system failure
- High process temperature in the Oxidizer Heater (I tem 11.11)

2 Heater damage and catalytic oxidizer damage

Low process temperature in the Oxidizer Heater (Item 11.12)

2 incomplete reaction

2

High pressure in the Catalytic.

Liquid stream entering heater

3

Gasket failure (13.7/11.11)

High pressure in the Catalytic

Oxidizer (Item 13.7)

Low pressure in the oxidizer

Low pressure in the oxidizer Heater (I tem 11.14)

None

High Pressure causing gaskjet

1 Waste spill

$3 . .3323$

Internal Detonation

1

3. .3323

- n...

Very high pressure
Internal safeties in heater

High temp sensor at oxidizer 
(cont inued)

\begin{tabular}{|c|c|c|c|c|c|c|c|}
\hline $\begin{array}{l}\text { It tem } \\
\text { Number }\end{array}$ & Deviation & Causes & $\begin{array}{l}\mathbf{F} \\
\mathrm{C}\end{array}$ & Consequences & FXETIĒŌ & Safeguards & Actions \\
\hline
\end{tabular}

13.0 VESSEL - Catalytic Oxidizer (dwg: E03025-RAA-102-D)

13.1 High Flow

13.2 Low Flow

13.5 High temperature

13.6 Low temperature

13.7 High pressure
High process flow in the

Oxidizer Heater (1 tem 11.8)

-

Oxidizer Heater (Item 11.8)

Carry-over of catalyst

beads/dust

Process upset (back pressure

increase at evaporator)

Incomplete reaction

Low/no process flow in the Oxidizer Heater (1tem 11.9)

- Low/no process flow in the Oxidizer Heater (Item 11.9)

High temperature (I tem 13.5)

- Catalyst damage

3 Vessel damage (leak/rupture)

High Organics

Electric heater SCR runaway.

External fire

High concentration of

contaminants (1 tem 13.9)

2 Gasket failure

1 High concentration of contaminants (1 tem 13.9)

None

High pressure in the Oxidized . High pressure in the Oxidized

Discharge Line (Item 12.7 )

Plugged lines

Low/no process flow in the Oxidizer Heater (Item 11.9)
Discharge Line (I tem 12.7)

- Low/no process flow in the Oxidizer Heater (Item 11.9) $\ldots \ldots$ see 11.8

...22

$\ldots \ldots 1$

....22

Delta Pressure indicator

$\ldots .11$

....12 Waste Blending

22.2223 Internal Heater safety

22.2223 High bed temp interlock to general shutdown

-...... 


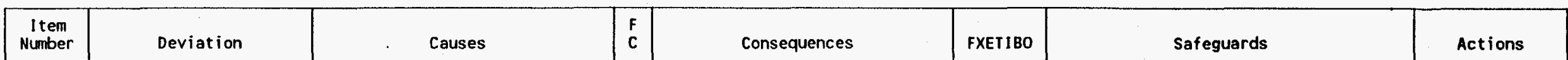

13.0 VESSEL - Catalytic oxidizer (continued)

13.8 Low pressure Low pressure in the oxidizer Heater (I tem 11.14)

13.9 High concentration of contaminants

\section{High temperature (Item 13.5)} RAD

Overpressure/Overtemperature Tube leak or rupture in the oxidizer Heater (Item 11.15) External Rupture (I tem 13.12)

13.13 High reaction rate

13.14 Low reaction rate
External Leak (Item 13.11)

None

Catalyst poison/deactivation
Low pressure in the oxidizer Heater (1 tem 11.14)

High temperature (item 13.5)

1 Mixed waste (cleanup problem)

Tube leak or rupture in the Oxidizer Heater (Item 11.15)

Acid gas release

co release

External Rupture (I tem 13.12)

External Leak (Item 13.11)
.032424 See 13.11

High high temp shutdown

See 10.1

RAD sensor in vapor discharge of evaporator

Foam sensors

level sensors ant $i$-foam injections

Design standards

sop

. .32314

$\ldots .0214$

....... 
(cont inued)

\begin{tabular}{|c|c|c|c|c|c|c|c|}
\hline $\begin{array}{l}\text { I tem } \\
\text { Nunituer }\end{array}$ & Deviation & Causes & $\begin{array}{l}\mathbf{F} \\
\mathrm{C}\end{array}$ & Consequences & FXETIBO & Safeguards & Actions \\
\hline
\end{tabular}

14.0 LiNE_X - liquid line from scrubber to Quench (dwg: E03025-RAA-102-D)

14.1 High flow

14.2 Low/no flow

14.3 Reverse flow

14.5 High temperature

14.6 Low temperature

14.7 High pressure
High process flow in the oxidizer Heater (Item 11.8 )

High liquid flow to quench

Plugged liquid feed / spray nozzle to quench

High level in scrubber (above quench di scharge)

Recirculation pump shutdown

High temperature (Item 14.5)

High pressure (Item 14.7)

High concentration of contaminants (1 tem 14.9)

Plugging in two phase line

Loss of quench liquid

Low/no flow (Item 14.2)

None

Low/no flow (Item 14.2)
- High process flow in the

oxidizer Heater (1 tem 11.8)

2 High back pressure to oxidizer

$\cdots \cdots \cdot$

3 High temperature to scrubber

No Flow/High back pressure

3 Corrosion in scrubber and

3 quench

Low back pressure due to no liquid flow (high temp scrubber)

- Pulsating liquid flow causing pulsating back pressure

High temperature (I tem 14.5)

High pressure (1 tem 14.7)

High concentration of contaminants (I tem 14.9)

3 Liquid back to oxidizer(steam explosion)

3 Low/no flow (Item 14.2)

..2..12 High level alarm in scrubber

.....11 Low level alarm in scrubber

....23 Pump motor operation indication

099
100

101

Low flow interlock on line 17

. .2 .12$

$\ldots \ldots 12$

.......

.......

$\ldots . . .$.

.322434 Design standards

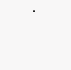

.

(2).

- Low/no flow (Item 14.2) $\quad \ldots \ldots$


(cont inued)

\begin{tabular}{|c|c|c|c|c|c|c|c|}
\hline $\begin{array}{l}\text { I tem } \\
\text { Number }\end{array}$ & Deviation & Causes & $\begin{array}{l}F \\
C\end{array}$ & Consequences & FXETIBO & Safeguards & Actions \\
\hline
\end{tabular}

14.0 LINE_X - liquid line from scrubber to Quench (cont inued)

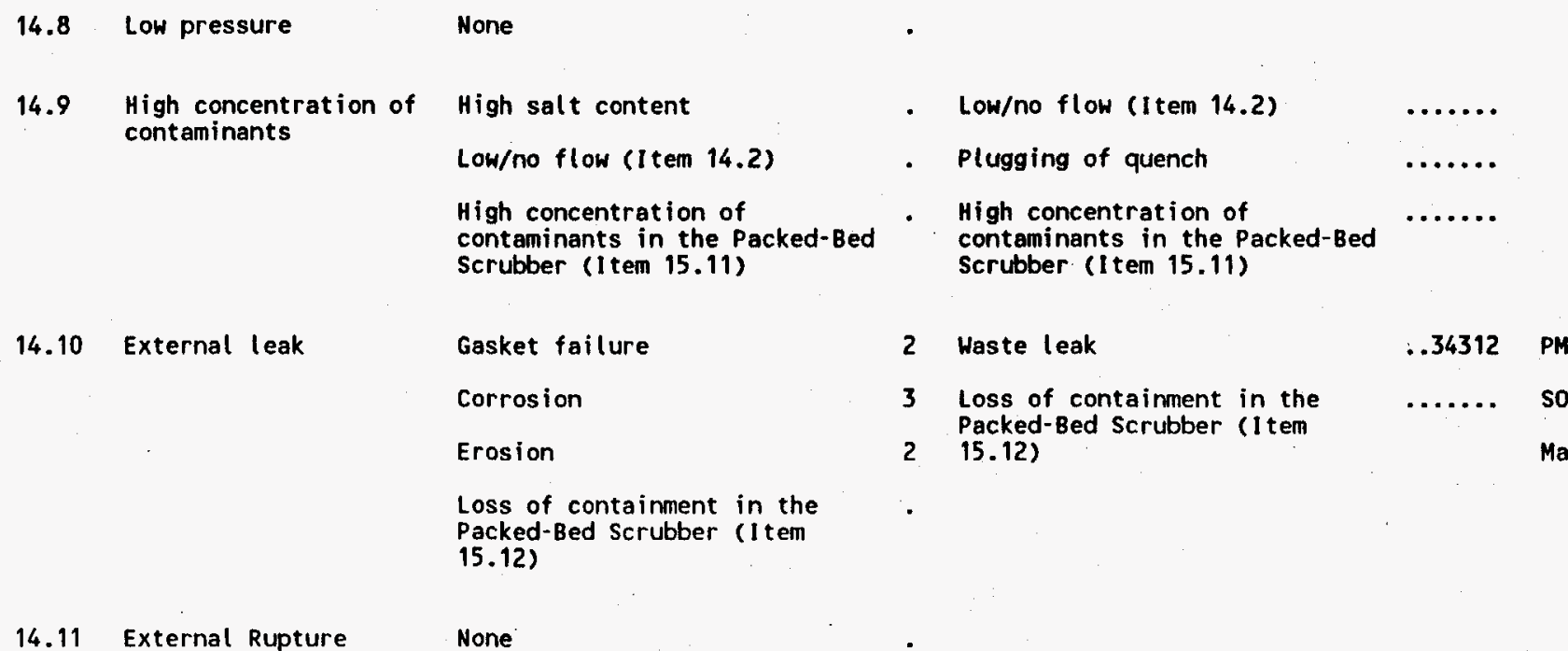

15.0 REACTOR_L - Packed-Bed Scrubber (dwg: E03025-RAA-102-D)

15.1 High flow High flow in the Evaporator
(Item 5.1)
- Toxic vapors to HEPA

Salts and corrosives to HEPA

Water to HEPA
..23322 See 5.1

..21322 Mist el iminator in scrubber

$. .2 . .12$
108 
(cont inued)

\begin{tabular}{|c|c|c|c|c|c|c|c|}
\hline $\begin{array}{l}\text { Item } \\
\text { Number }\end{array}$ & Deviation & Causes & $\begin{array}{l}\mathbf{F} \\
\bar{C}\end{array}$ & Consequences & FXET IBO & Safeguards & Actions \\
\hline
\end{tabular}

15.0 REACTOR_L - Packed-Bed Scrubber (continued)

15.2 Low/no flow

15.3 Reverse flow

15.4 Misdirected flow

15.5 High temperature

15.6 Low temperature

15.7 High reaction rate
Clogged vent line

High flow in the Scrubber

Liquid Recirculation Line

(I tem 17.1)

Clogged packing

High pressure (I tem 15.9)

None

None

Quench failure

Loss of scrubber solution (instrument and/or pump

failure)

Low Level (I tem 15.14)

None

Heat of dilution of caustic (possible during startup)

(possible during startup)

2 High back pressure (See previous high pressure consequences)

Corrosion (from condensed acid gases)

High pressure (Item 15.9)

- High flow in the scrubber Liquid Recirculation Line (I tem 17.1)

3 Packing Plugging

2 Over temperature of scrubber(scrubber failure) Uncontrolled release of acid $\quad .23322$ gas to HEPA
Delta $P$ across scrubber

Pressure indication on vent $l$ ine

Conductivity of scrubber liquor

Pressure indications throughout system 
(cont inued)

\begin{tabular}{|c|c|c|c|c|c|c|c|}
\hline $\begin{array}{l}\text { I tem } \\
\text { Number }\end{array}$ & Deviation & Causes & $\begin{array}{l}F \\
C\end{array}$ & Consequences & FXETIBO & Safeguards & Actions \\
\hline
\end{tabular}

15.0 REACTOR_L - Packed-Bed Scrubber (cont inued)

15.8 Low reaction rate

15.9 High pressure

15.10 Low pressure

15.11 High concentration of contaminants

15.12 Loss of containment
Loss of caustic

High concentration of contaminants (I tem 15.11)

Low/no flow in the Scrubber Liquid Recirculation Line

(I tem 17.2)

Low/no flow (1tem 15.2)

None

High concentration of contaminants in the $D$ ischarge line from oxidizer to scrubber (Item 14.9)

Low reaction rate (1tem 15.8 )

High concentration of

contaminants in the Process

Crom Scrubber (I tem

16.13)

External leak in the Discharge

line from oxidizer to scrubber (item 14.10)
4. No scrubbing action

. .23122

Inl ine $\mathrm{pH}$ monitor

Bicarb plugging (shutdown and dig out)

- Corrosion

High concentration of contaminants (I tem 15.11)

- Low/no flow (Item 15.2)

High concentration of High concentration of contaminants in the Discharge (Item 14.9)

- Low reaction rate (1 tem 15.8 )

- High concentration of contaminants in the Process Vent Line from scrubber (I te 16.13)

.....23

Manual sampling

Conductivity monitor

....23

Pressure Delta across packing

External leak in the Discharge

line from oxidizer to scrubber

(1 tem 14.10)

116 
(cont inued)

\begin{tabular}{|c|c|c|c|c|c|c|c|}
\hline $\begin{array}{l}\text { I tem } \\
\text { Number }\end{array}$ & Deviation & Causes & $\begin{array}{l}F \\
C\end{array}$ & Consequences & FXETIBO & Safeguards & Actions \\
\hline
\end{tabular}

15.0 REACTOR_L - Packed-Bed Scrubber (cont inued)

15.13 High Leve

15.14 Low Level

16.1 High flow

16.2 Low/no flow
2 flood scrubber

$2 \quad$ Flood system when system down and water valve open.

Blowdown valve sticks closed Low/no flow in the Scrubber Blowdown line (I tem 18.2)

Blowdown valve stuck open Water addition valve sticks closed

Level transmitter failure

2

High System backpressure

3 Loss of scrubber effiency

2 High temperature (Item 15.5) Loss scrubber liquid flow
Low/no flow in the Scrubber Liquid Recirculation Line (I tem 17.2)
.....11 Pressure indicators in system

Del ta $P$ indicators

$\ldots .11$

32112 Flow meter

Low level alarm

.......

16.0 LINE - Process Vent Line from Scrubber (dwg: E03025-RAA-102-D)

HEPA Plug

High pressure (Item 16.7)

High flow anywhere else $\quad$ Overload HEPA filter

- High pressure (Item 16.7)
3..13 Flow monitor / pressure / temperature

Delta $P$ across first HEPA

RAD monitor

....11 Pressure indicator

...... Delta $P$ across first HEPA filter

flow meter in line 
(cont inued)

\begin{tabular}{|c|c|c|c|c|c|c|c|}
\hline $\begin{array}{l}\text { I tem } \\
\text { Number }\end{array}$ & Deviation & Causes & $\begin{array}{l}F \\
C\end{array}$ & Consequences & FXETIBO & Safeguards & Actions \\
\hline
\end{tabular}

16.0 LINE - Process Vent Line from Scrubber (continued)

16.6 Low temperature

Failure of heat trace

HEPA Plug

Low/no flow (Item 16.2)

Valve not open

None contaminants

Liquid overspray

High concentration of contaminants in the Packed-Bed Scrubber (Item 15.11)
16.13 High concentration of Mercury in waste
2 Burnout downstream instruments

$\ldots \ldots 11$

Temperature control on trace

$\ldots .11$ Low low temperature interlock

2 Low/no flow (1 tem 16.2)

- $\cdots \cdots$

128

2

2 Mercury vapor in building $\quad .34 .44$ ventilation system

High concentration of

contaminants in the Packed-Bed

Scrubber (1 tem 15.11)

2 Vapor release

124

125
126

127

29 $\ldots .211$
16.14 Loss of containment

Gasket failure
130
131 


\begin{tabular}{|c|c|c|c|c|c|c|c|}
\hline $\begin{array}{l}\text { I tem } \\
\text { Number }\end{array}$ & Deviation & Causes & $\begin{array}{l}\mathrm{F} \\
\mathrm{C}\end{array}$ & Consequences & FXETIBO & Safeguards & Actions \\
\hline
\end{tabular}

17.0 LINE_P - Scrubber Liquid Recirculation Line (dwg: E03025-RAA-102-D)

17.1 High flow

17.2 Low/no flow
Low/no flow in the Packed-Bed Scrubber (Item 15.2)

Quench throttle valve left closed

Leak in the Scubber Blowdown Storage Container (I tem 19.6)

clogged Packing in Scrubber

clogged vent line

Pump failure

Line clogged

Throttle valve closed

scrubber blodown valve open

Packing $\mathrm{clog}$

Low Level in the Packed-Bed Scrubber (I tem 15.14)

High pressure (I tem 17.7)

Low pressure (1tem 17.8)

\begin{abstract}
17.3 Reverse flow
17.4 Misdirected flow

$17.5 \quad H i g h$ temperature
\end{abstract}

Blowdown valve open

None Low reaction rate in the
Packed-Bed Scrubber (I tem 3 15.8)

3 High pressure (I tem 17.7)

2 No scrubbing action

2 Bicarbonate plugging

Corrosion

Flow meter in line with alarm

132
133

3 No safety problem

Level indicator in scrubber

134 Flow meter with low low waste feed shutoff

Pump fail indicator

\section{. .23122}

....23

$\cdot$

Misdirected to Line 18 (possible waste spill) 


\begin{tabular}{|c|c|c|c|c|c|c|c|}
\hline $\begin{array}{l}\text { Item } \\
\text { Number }\end{array}$ & Deviation & Causes & $\begin{array}{l}F \\
C\end{array}$ & Consequences & FXETIBO & Safeguards & Actions \\
\hline
\end{tabular}

17.0 LINE_P - Scrubber Liquid Recirculation Line (cont inued)

$\begin{array}{lll}17.6 & \text { Low temperature } & \text { None } \\ 17.7 & \text { High pressure } & \text { Low/no flow (Item 17.2) } \\ 17.8 & \text { Low pressure } & \begin{array}{l}\text { Pump Failure } \\ \text { Instrumentation Failure } \\ \end{array} \\ & \text { Blowdown / sample valve open }\end{array}$

17.9 High concentration of $\mathrm{CO} 2$ absorption at high pH contaminants

17.10 External Leak followed by $\mathrm{pH}$ drop

Low pH - failure to neutralize

acid gases

High flow in the Sodium

Hydroxide Feed Line (Item

21.1)

Low/no flow in the Sodium Hydroxide Feed Line (I tem

21.2)

\section{Gasket leak}

Corrosion

Pump seal

External leak in the Scrubber Blowdown line (1tem 18.10)

Rupture in the Scubber

Blowdown Storage Container (I tem 19.7)
Low/no flow (Item 17.2)

Low/no flow (I tem 17.2)

Scrubber liquid spilt

SOP (sample valve)

136

. .113 .2$

2

2 Bicarbonate plugging of tine

Corrosion

$\ldots .12$ SOP

$\ldots .12$ pH control system

137

Scrubber liquid spill

External Leak in the Scrubber

Blowdown line (Item 18.10)
...212 Materials of construction

pH control system 
(cont inued)

\begin{tabular}{|c|c|c|c|c|c|c|c|}
\hline $\begin{array}{l}\text { I tem } \\
\text { Number }\end{array}$ & Deviation & Causes & $\begin{array}{l}F \\
C\end{array}$ & Consequences & FXETIBO & Safeguards & Actions \\
\hline
\end{tabular}

17.0 LINE_P - Scrubber Liquid Recirculation Line (cont inued)

17.11 External Rupture

18.1 High flow

Valve stuck open

Plugged line

Valve stuck shut

slow filling rate in the Scubber Blowdown Storage Container (1 tem 19.9)

18.3 Reverse flow

None

18.5 High temperature

18.6 Low temperature

None

18.7 High pressure

$18.8 \quad$ Low pressure

None

18.9 High concentration of None contaminants
3 Scrubber liquid spill

$\ldots 212$

140

3 High Level in the Packed-Bed Scrubber (1 tem 15.13)

3 slow filling rate in the Scubber Blowdown Storage Container (I tem 19.9)

High pressure in the Sodium

Hydroxide Feed Line (I tem
21.7 )

None

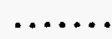

High level interlock on scrubber 
(cont inued)

\begin{tabular}{|c|c|c|c|c|c|c|c|}
\hline $\begin{array}{l}\text { I tem } \\
\text { Number }\end{array}$ & Deviation & Causes & $\begin{array}{l}\mathbf{F} \\
\mathbf{C}\end{array}$ & Consequences & FXETIBO & Safeguards & Actions \\
\hline
\end{tabular}

18.0 LINE - Scrubber Blowdown line (cont inued)

18.10 External Leak

19.3 High Level

19.4 Low Level

19.5 Contamination

19.6 Leak

None
External Leak in the Scrubber Liquid Recirculation Line (I tem 17.10)

Valve packing leak

19.0 VESSEL - Scubber Blowdown Storage Container (dwg: E03025-RAA-102-D)
External Leak in the Scrubber Liquid Recirculation Line (I tem 17.10)

3 Scrubber liquid leak

$\ldots .212$
19.1 High Temperature None
19.2 LoH Temperature None

19.1 High Temperature None
19.2 LoH Temperature None

No level instrumentation

Corrosion

Catalyst breakdown

Evaporator Burp

Leak in the Brine Concentrate . High flow in the Scrubber
Storage Container (Item 8.6 ) Storage Container

RAD contamination

2
Scrubber liquid spill

$\ldots .212$

141
142

5

1 Chromium in scrubber liquid

..32.2. pH control system

143

.32 .34

(Item 17.1)

scrubber liquid leak

. .34312 
(cont inued)

\begin{tabular}{|c|c|c|c|c|c|c|c|}
\hline $\begin{array}{l}\text { Item } \\
\text { Nininer }\end{array}$ & Deviation & Causes & $\begin{array}{l}\mathbf{F} \\
\mathbf{C}\end{array}$ & Consequences & FXETIBO & Safeguards & Actions \\
\hline
\end{tabular}

19.0 VESSEL - Scubber Blowdown storage Container (continued)

19.7 Rupture

Dropped drum

19.8 High filling Rate

19.9 Slow filling rate

20.1 High flow

\begin{abstract}
20.2 Low/no flow
20.3 Reverse flow
\end{abstract}

20.4 Misdirected flow

20.5 High temperature

Empty cylinder

Pressure regulator failure

Control valve stuck open

Instrumentation failure

Regulator failure

Empty cylinder
2 External Leak in the Scrubber

Liquid Recirculation Line

(I tem 17.10)

Scrubber liquid spill

. .34312

None

- Low/no flow in the Scrubber

Blowdown line (Item 18.2)

No safety problem

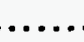

$\ldots$

20.0 LINE - Propane feed Line (dwg: E03025-RAA-102-D)

2 Possible mixture above LEL

No safety concern

1 Contamination of propane line

No consequences of interest

\section{3..324 Flow meter in propane line} Pressure indicator on propane regulator

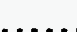

$\ldots . .11$ Pressure indicator in propane line Flow meter in propane line
148 
(cont inued)

\begin{tabular}{|c|c|c|c|c|c|c|c|}
\hline $\begin{array}{c}\text { Item } \\
\text { Number }\end{array}$ & Deviation & Causes & $\begin{array}{l}F \\
C\end{array}$ & Consequences & FXETIBO & Safeguards & Actions \\
\hline
\end{tabular}

20.0 LINE - Propane Feed Line (continued)

20.6 Low temperature

20.7 High pressure

Regulator failure

20.8 Low pressure

20.9 High concentration of None . contaminants

20.10 External Leak

20.11 External Rupture

21.1 High flow
Leaking valve

fitting leaks

Knock head off cylinder
Ambient room temperature

Low flow rate

- Not a safety concern

None

2 Propane leak

$3 . .312$ SOP

1 Large release of propane / flying cylinder
PM

(......

.......

SOP

...... SOP

Sodium Hydroxide Feed Line (dwg: E03025-RAA-102-D)

Uncontrol led pumps due to instrumentation failure $(\mathrm{PH}$ probe in waste feed tank)
1 Loss of $\mathrm{pH}$ control

High concentration of

contaminants in the Scrubber

Liquid Recirculation Line

(I tem 17.9)

LOW/HIGH CONCENTRATION in the

WASTE FEED TANK (I tem 2.7)

High. flow in the Sulfuric Acid

feed Line (I tem 22.1)
....11 Conductivity meter on scrubber

....... Punp sizing

Temperature / pH meter on evaporator 
(cont inued)

\begin{tabular}{|c|c|c|c|c|c|c|c|}
\hline $\begin{array}{l}\text { I tem } \\
\text { number }\end{array}$ & Deviation & Causes & $\begin{array}{l}\mathrm{F} \\
\mathrm{C}\end{array}$ & Consequences & FXETIBO & Safeguards & Actions \\
\hline
\end{tabular}

21.0 LINE - Sodium Hydroxide Feed Line (continued)

21.2 Low/no flow

21.3 Reverse flow

21.4 Misdirected flow

$21.5 \quad H i g h$ temperature

21.6 Low temperature

$21.7 \quad$ High pressure

21.8 Low pressure
None

Plugged line

Pump failure

Empty caustic drum

Frozen line

Valve closed

Low pressure (Item 21.8)

None

Condensation in line

Low Room temperature

Low/no flow in the Scrubber Blowdown line (1 tem 18.2)

High pressure in the sulfuric Acid feed Line (Item 22.7)
- Loss of pH control

High concentration of contaminants in the Scrubber Liquid Recirculation Line (Item 17.9)

- LOW/HIGH CONCENTRATION in the WASTE FEED TANK (Item 2.7)

- Low pressure (I tem 21.8) Low/no flow in the sulfuric Acid Feed Line (Item 22.2)

- Loss of pH control

Caustic Spill

High pressure in the sulfuric High pressure in the Sulfuric
Acid Feed Line (Item 22.7)

...311 Internal relief specified for pumps
Check valves

Positive displacement pumps

Check valves

SOP

$\ldots \ldots 11$ SOP

$\begin{array}{ll}\ldots \ldots 11 & \text { SOP } \\ \ldots \ldots . . & \text { PM }\end{array}$

Conductivity meter on scrubber

pH meter on evaporator

....

Low/no flow (Item 21.2)

- Low/no flow (I term 21.2) 
(cont inued)

\begin{tabular}{|c|c|c|c|c|c|c|c|}
\hline $\begin{array}{l}\text { I tem } \\
\text { Number }\end{array}$ & Deviation & Causes & $\begin{array}{l}\mathbf{F} \\
\mathbf{C}\end{array}$ & Consequences & FXETIBO & Safeguards & Actions \\
\hline
\end{tabular}

21.0 LINE - Sodium Hydroxide Feed Line (cont inued)

21.9 High concentration of None contaminants

21.10 External Leak

Leaking fitting

valve packing
- Caustic leak

- External Leak in the Sulfuric Acid feed line (Item 22.10)
...311 PM

Material of construction

22.0 LINE - sulfuric Acid Feed Line (dwg: E03025-RAA-102-D)

22.1 High flow

22.2 Low/no flow

22.3 Reverse flow

22.4 Misdirected flow

$22.5 \quad$ High temperature

22.6 Low temperature
High flow in the sodium Hydroxide Feed Line (Item 21.1)

Low/no flow in the Sodium Hydroxide Feed Line (Item 21.2)

except freezing

None

None

None

None
- Acid spill

pH control loss in waste feed tank (corrosion problems)

....322 $\mathrm{pH}$ probes in evaporator

- Loss of pH control (hydroxide gel problems)

$\ldots \ldots 11$

probes

SOP

PM

Check valve

pump selection 
(cont inued)

\begin{tabular}{|c|c|c|c|c|c|c|c|}
\hline $\begin{array}{l}\text { Item } \\
\text { Number }\end{array}$ & Deviation & Causes & $\begin{array}{l}F \\
C\end{array}$ & Consequences & FXETIBO & Safeguards & Âctions \\
\hline
\end{tabular}

22.0 LINE - sulfuric Acid Feed Line (continued)

22.7 High pressure

22.8 Low pressure

22.9 High concentration of contaminants

22.10 External Leak

22.11 External Rupture
High pressure in the sodium

Hydrox

None

None

External Leak in the Sodium External Leak in the Sodium Hydrox
$21.10)$

External Leak (Item 22.10) Drop the drum
- High pressure in the Sodium Hydroxide Feed Line (Item 21.7)

Acid spill and fume

External Rupture (Item 22.11)

$\ldots . .414$

SOP

...... PM

.3 .424 SOP

PM
154
155

156
157

23.0 LINE - Feed Tank Vent Line (dwg: E03025-RAA-102-D)

\subsection{High Flow \\ 23.2 LOW/NO FlOW}

23.3 REVERSE FLOW
None

Closed valve

Plugged check valve

Check valve failure
2 Pressure build up in tank

2 Can't feed waste tank

1 Vapor from evaporator feed back to waste tank

\section{....14 Relief valve}

.....11 Pressure guage

Delta $P$ interlock on feed tank and evaporator 


\begin{tabular}{|c|c|c|c|c|c|c|c|}
\hline $\begin{array}{l}\text { I tem } \\
\text { Number }\end{array}$ & Deviation & Causes & $\begin{array}{l}\mathbf{F} \\
\mathbf{C}\end{array}$ & Consequences & FXETIBO & Safeguards & Actions \\
\hline
\end{tabular}

23.0 LINE - Feed Tank Vent Line (cont inued)

\begin{tabular}{|c|c|c|c|c|c|c|}
\hline 23.5 & High Temperature & $\begin{array}{l}\text { External fire } \\
\text { Check valve faiture allowing } \\
\text { hot gas to enter waste feed } \\
\text { tank }\end{array}$ & $\begin{array}{l}1 \\
.\end{array}$ & $\begin{array}{l}\text { See tank and evaporator } \\
\text { consequences }\end{array}$ & $\cdots \cdots$ & \\
\hline 23.5 & Low Temperature & & & None & $\cdots \ldots \ldots$ & \\
\hline 23.6 & High Pressure & Line block & - & Relief valve release & $\ldots .23$ & Pressure indicator on tank \\
\hline 23.7 & Low Pressure & & & None & ...... & \\
\hline \multirow[t]{3}{*}{23.8} & $\begin{array}{l}\text { LOW/HIGH } \\
\text { CONCENTRATION }\end{array}$ & Overfilling feed tank & 2 & Agitator/pumping problems & $\ldots \ldots 11$ & Waste sampling and feed procedures \\
\hline & & $\begin{array}{l}\text { Too much solvent in aste tank } \\
\text { Too high suspended solids in } \\
\text { waste tank }\end{array}$ & $\begin{array}{l}1 \\
1\end{array}$ & $\begin{array}{l}\text { ph out of specification } \\
\text { (corrosion) }\end{array}$ & $\ldots \ldots 11$ & Haste acceptance criteria \\
\hline & & Improper pH adjustment & 3 & & & \\
\hline 23.9 & CONTAMINATION & Improper waste feed & 1 & Clogging of waste line & $\ldots \ldots 11$ & Waste acceptance criteria \\
\hline \multirow[t]{5}{*}{23.10} & EXTERNAL LEAK & Gasket failure & 2 & Small waste vapor spill & $\ldots 2222$ & System setup procedures \\
\hline & & Unexpected reaction in tank & 2 & & & Waste acceptance criteria \\
\hline & & Corrosion & 1 & & & PM \\
\hline & & Vacuum breaker leak & 2 & . & & \\
\hline & & PSV leak & 2 & & & \\
\hline
\end{tabular}


(cont inued)

\begin{tabular}{|c|c|c|c|c|c|c|c|}
\hline $\begin{array}{l}\text { I tem } \\
\text { Number }\end{array}$ & Deviation & Causes & $\begin{array}{l}F \\
C\end{array}$ & Consequences & FXETIBO & Safeguards & Actions \\
\hline
\end{tabular}

23.0 LINE - Feed Tank Vent Line (continued)

23.11 EXTERNAL RUPTURE

Unexpected reaction in tank

1 Waste vapor release

...2222 Sampling/waste acceptance criteria 


\section{C.2 HAZOP Analysis Action Item Tracking and Risk Reduction}

The HAZOP analysis review identified 159 "action items" to be considered as possible mitigators for the various deviations. These action items are enumerated in the right-hand column of Attachment C.1-1, Table C.1-3, HAZOP Analysis Action Items. Table C.2-1 lists each action item in numerical order, along with the deviation it addressed, the priority of that deviation, a description of the action item, and a statement giving the resolution of the action item or the current status if an item has not been closed out. (An example of an item that is not yet closed out is one that must be addressed during preparation of standard operating procedures [SOPs], which is outside the scope of this project.)

The "Priority" shown for each action item listed in Table C.2-1 was determined by combining the frequency and consequence ratings for the deviation associated with that item. These ratings ranged from 1 to 4 , with 4 being the highest. Therefore, the highest priority items were those with a rating of 8 . Only two high-priority items were identified: (1) foaming or undetected high level in the evaporator resulting in carryover of liquid into the oxidizer heaters, which in turn could cause an explosion due to thermal stresses in the heaters; and (2) low/no process flow in the Econobator inlet line; which could create an explosive situation due to high propane concentration.

Liquid carryover from the evaporator was mitigated by adding redundant level and foam instrumentation and by modifying the design of the evaporator to the current multichambered design which adds two stages of demisting and a very circuitous flow path. The risk of the low/no Econobator inlet flow scenario was mitigated by deleting the propane addition and replacing it with ethanol, added as a liquid to the evaporator feed. The presence of a small concentration of ethanol, a flammable liquid, at a point in the process (the evaporator) where small concentrations of flammable liquids are normal, adds no additional hazards to the system.

Deletion of propane addition resolved a total of 17 of the HAZOP analysis action items. Another source of major hazards was the quench system on the Econobator off gas; deletion of this system and replacement with the noncontact desuperheater resolved an additional 10 items.

Table C.2-1. Mitigation of HAZOP Analysis Action Items

$\begin{array}{ll}\text { Item No:: } & 1 \\ \text { Deviation: } & 1.2-\text { Low/No Flow, Waste Transfer to Waste Feed Tank } \\ \text { Priority: } & 5 \\ \text { Description: } & \text { Maintenance training } \\ \text { Status: } & \text { To be resolved during training } \\ & \\ \text { Item No:: } & 2 \\ \text { Deviation: } & 1.3-\text { Reverse Flow, Waste Transfer to Waste Feed Tank } \\ \text { Priority: } & 4 \\ \text { Description: } & \text { Review maintenance procedures including PPE } \\ \text { Status: } & \text { To be resolved during training } \\ & \\ \text { Item No.: } & 3 \\ \text { Deviation: } & 1.3-\text { Reverse Flow, Waste Transfer to Waste Feed Tank } \\ \text { Priority: } & 4 \\ \text { Description: } & \text { Siphon break on dip tube } \\ \text { Status: } & \text { Complete } \\ \text { Action: } & \text { Added per DCN-01 }\end{array}$


Item No.: 4

Deviation: 1.9 - Contamination, Waste Transfer to Waste Feed Tank

Priority: 7

Description: Consider drum mixer on waste feed drum

Status: $\quad$ To be resolved during training

Item No.: 5

Deviation: 1.9 - Contamination, Waste Transfer to Waste Feed Tank

Priority: 7

Description: Consider settling and decantation possibility in waste feed drum

Statuls: $\quad$ To be resolved during training

Item No.: 6

Deviation: $\quad 1.10$ - External Leak, Waste Transfer to Waste Feed Tank

Priority: 4

Description: Hydro testing before startup included in SOP

Status: $\quad$ To be resolved during training

Item No.: 7

Deviation: 2.2 - High Pressure, Waste Feed Tank

Priority: 4

Description: Rate tank at same pressure as evaporator

Status: $\quad$ Complete

Action: Done

Item No.: 8

Deviation: $\quad 2.2$ - High Pressure, Waste Feed Tank

Priority: 4

Description: Relief valve discharge management requirements

Status: Complete

Action: Will route to unit vent line

Item No.: $\quad 9$ (Duplicated by Items 10 and 82)

Deviation: $\quad 2.5$ - Low Level, Waste Feed Tank

Prionity: 4 .

Description: Two independent indicators on waste feed tank

Status: Complete

Action: Added float switch

Item No.: 10 (duplicate of Item 9)

Item No: $\quad 11$

Deviation: $\quad 2.6$ - High Level, Waste Feed Tank

Priority: 7

Description: Remove vacuum breaker from waste feed tank

Status: Complete

Action: Deleted per DCN-01 
Item No. 12

Deviation: $\quad 2.7$ - Low/High Concentration, Waste Feed Tank

Priority: 7

Description: Revisit waste acceptance of complex cyanides

Status: $\quad$ To be resolved during training

Item No.: 13

Deviation: $\quad 2.7$ - Low/High Concentration, Waste Feed Tank

Priority: 7

Description: Evaluate high solvent consequences (Node 5 \& 13)

Status: $\quad$ Complete

Action: High solvents will be fed directly to evaporator

Item No.: $\quad 14$

Deviation: $\quad 2.7$ - Low/High Concentration, Waste Feed Tank

Priority: $\quad 7$

Description: Schedule drums to minimize acidification

Status: $\quad$ To be resolved during training

Item No.: 15 (Duplicated by Items $153,154,156$, and 157)

Deviation: $\quad 2.7$ - Low/High Concentration, Waste Feed Tank

Priority: $\quad 7$

Description: Consider elimination or restricted use of acid (corrosion concerns in evaporator)

Status: $\quad$ Complete

Action: $\quad$ pH range $>7$, acid volume 5 gals max

Item No.: $\quad 16$

Deviation: $\quad 2.9$ - External Leak, Waste Feed Tank

Priority: 7

Description: Use double agitator seal with vent to HEPA filter

Status: $\quad$ Complete

Action: Using air-driven agitator - no explosion source

Item No.: $\quad 18$

Deviation: $\quad 2.9$ - External Leak, Waste Feed Tank

Priority: 7

Description: PSV on waste feed tank should have a sealed bonnet

Status: $\quad$ Complete

Action: $\quad$ Added PSE per DCN-01

Item No.: 19

Deviation: 2.9 - External Leak, Waste Feed Tank

Priority: 7

Description: Rupture disk/blowout on waste feed tank

Status: $\quad$ Complete

Action: $\quad$ Added PSE per DCN-01 
Item No.: $\quad 20$

Deviation: $\quad 2.9$ - External Leak, Waste Feed Tank

Priority: 7

Description: Review possibility of exothermic/detonation reaction

Status: $\quad$ Complete

Action: Add interlock for feed tank temperature

Item No.: $\quad 21$

Deviation: $\quad 2.10$ - External Rupture, Waste Feed Tank

Priority: 5

Description: Consider worst case situation for reaction possibility in feed tank

Status: $\quad$ Complete

Action: $\quad$ See item 20

Item No:: 22

Deviation: $\quad 2.10$ - External Rupture, Waste Feed Tank

Priority: 5

Description: Class 1, Div 1 in waste feed area

Status: $\quad$ Complete

Action: $\quad$ Air-driven mixer

Item No.: 23

Deviation: $\quad 3.2$ - Low/No Flow, Waste Feed Line from Tank to Evaporator

Priority: 5

Description: Add manual valves to be able to isolate evaporator from feed lines

Status: $\quad$ Complete

Action: Done per DCN-01

Item No.: $\quad 24$ (Duplicated by Item 27)

Deviation: $\quad 3.2$ - Low/No Flow, Waste Feed Line from Tank to Evaporator

Priority: 5

Description: Combine discharges of P-014, P-122, and P-054

Status: $\quad$ Complete

Action: Done per DCN-01

Item No: $\quad 25$

Deviation: $\quad 3.2$ - Low/No Flow, Waste Feed Line from Tank to Evaporator

Priority: 5

Description: Relocate waste feed line above liquid level in evaporator

Status: Complete

Action: $\quad$ Done per DCN-01

Item No.: 26

Deviation: $\quad 3.4$ - Misdirected Flow, Waste Feed Line from Tank to Evaporator

Priority: 3

Description: Confirm check valves in all metering pumps

Status: In progress

Item No.: $\quad 27$ (duplicate of Item 24) 
Item No.: $\quad 28$

Deviation: $\quad 3.7$ - High Pressure, Waste Feed Line from Tank to Evaporator

Priority: 4

Description: Verify metering pumps have internal PSV

Status: In progress

Item No.: $\quad 29$

Deviation: $\quad 3.7$ - High Pressure, Waste Feed Line from Tank to Evaporator

Priority: 4

Description: Check pressure rating of line.

Status: $\quad$ Complete

Action: Rating OK

Item No: $\quad 30$

Deviation: $\quad 4.1$ - Shell Leak, Evaporator Heater

Priority: 7

Description: Delete vacuum breaker / elevate heater above trap

Status: $\quad$ Complete

Action: $\quad$ Vacuum breaker deleted per DCN-01

Item No:: 31

Deviation: $\quad 4.1$ - Shell Leak, Evaporator Heater

Priority: 7

Description: Steam condensate receiver open to atmosphere

Status: . Complete

Action: Done per DCN-01

Item No.: $\quad 32$

Deviation: $\quad 4.1$ - Shell Leak, Evaporator Heater

Priority: 7

Description: SOP to include hydrotest requirements, etc.

Status: $\quad$ To be resolved during training

Item No.: $\quad 33$

Deviation: $\quad 4.5$ - Low Pressure, Evaporator Heater

Priority: None given

Description: Confirm heater is designed for vacuum

Status: Complete

Action: Done

Item No.: $\quad 34$

Deviation: $\quad 4.7$ - High Level, Evaporator Heater

Priority: $\quad 3$

Description: Vent shell to atmosphere

Status: Complete

Action: $\quad$ Vent added per DCN-01 
Item No.: $\quad 35$

Deviation: $\quad 4.10$ - Tube Leak, Evaporator Heater

Priority: 5

Description: Consider testing condensate for gross Alpha and Beta

Status: $\quad$ To be resolved during training

Item No: $\quad 36$

Deviation: $\quad 5.2$ - Low/No Flow, Evaporator

Priority: 7

Description: Design evaporator for higher pressure than boiler capacity

Status: $\quad$ Complete

Action: Not practical

Item No: $\quad 37$

Deviation: $\quad 5.2$ - Low/No Flow, Evaporator

Priority: 7

Description: Differential pressure across mesh pads

Status: Complete

Action: Not required per Wheelabrator Clean Water

Item No.: 38

Deviation: $\quad 5.2$-Low/No Flow, Evaporator

Priority: 7

Description: Water spray under mesh pads

Status: Complete

Action: Not required per Wheelabrator Clean Water

Item No.: 39

Deviation: $\quad 5.5$ - High Temperature, Evaporator

Priority: 5

Description: SOP - Sampling and analysis

Status: $\quad$ To be resolved during training

Item No.: $\quad 40$

Deviation: $\quad 5.7$ - High pressure, evaporator

Priority: 3

Description: Coordinate relief valve with boiler relief pressure

Status: $\quad$ Complete

Action: $\quad$ Not practical (see item 36)

Item No.: 41 (duplicated by Item 76)

Deviation: $\quad 5.9$ - High Level, Evaporator

Priority: 8

Description: Wide spot in line 10 - knockout pot

Status: $\quad$ Complete

Action: Incorporated into evaporator design

Item No.: $\quad 42$ (duplicate of Item 115) 
Item No.: $\quad 43$

Deviation: $\quad 5.10$ - Low Level, Evaporator

Priority: 4

Description: Redundant low level switch (utilize density dP)

Status: Complete

Action: $\quad \mathrm{dP}$ added per $\mathrm{DCN}-01$

Item No: $\quad 44$

Deviation: $\quad 5.15$ - External Leak, Evaporator

Priority: 3

Description: Corrosion coupons

Status: In progress

Item No.: $\quad 45$

Deviation: $\quad 6.2$ - Low/No Flow, Brine Recirculation Line w/ Pump

Priority: 7

Description: Motor amp monitor replacing flow meter

Status: In progress

Item No.: $\quad 46$

Deviation: $\quad 6.4$ - Misdirected Flow, Brine Recirculation Line w/ Pump

Priority: None listed

Description: Check current safeguard

Status: $\quad$ To be resolved during training

Item No.: $\quad 47$

Deviation: $\quad 6.7$ - High Pressure, Brine Recirculation Line w/ Pump

Priority: 1

Description: Replace throttling valve with fixed orifice - remove relief valve

Status: $\quad$ Complete

Action: $\quad$ Added orifice and removed PSV

Item No.: 48

Deviation: $\quad 6.8$ - Low Pressure, Brine Recirculation Line w/ Pump

Priority: 1

Description: Redundant low-level indicator

Status: Complete

Action: $\quad \mathrm{dP}$ added per $\mathrm{DCN}-01$

Item No.: 49.

Deviation: $\quad 7.1$ - High Flow, Brine Concentrate Drain Line

Priority: 5

Description: Consider a ram valve and a manual back-up valve

Status: Complete

Action: Manual ram valve added per DCN-01 
Item No.: $\quad 50$

Deviation: $\quad 7.2$ - Low/No Flow, Brine Concentrate Drain Line

Priority: 4

Description: Ram valve and a manual back-up valve

Status: Complete

Action: Manual ram valve added per $\mathrm{DCN}-01$

Item No.: $\quad 51$

Deviation: $\quad 7.2$ - Low/No Flow, Brine Concentrate Drain Line

Priority: 4

Description: Steam / water flush line

Status: $\quad$ Complete

Action: $\quad$ Added to P\&ID

Item No.: $\quad 52$

Deviation: $\quad 7.6$ - Low Temperature, Brine Concentrate Drain Line

Priority: 2

Description: Preheat procedure before draining

Status: $\quad$ To be resolved during training

Item No: $\quad 53$

Deviation: $\quad 7.6$ - Low Temperature, Brine Concentrate Drain Line

Priority: 2

Description: Steam trace line

Status: $\quad$ Complete

Action: Item 51 will be implemented

Item No:: $\quad 54$

Deviation: $\quad 8.3$ - High Level, Brine Concentrate Storage Container

Priority: 2

Description: Platform scale

Status: $\quad$ Complete

Action: Load cells will be utilized

Item No.: $\quad 55$

Deviation: $\quad 8.3$ - High Level, Brine Concentrate Storage Container

Priority: 2

Description: Drain procedures

Status: $\quad$ To be resolved during training

Item No.: $\quad 56$

Deviation: $\quad 8.6$ - Leak, Brine Concentrate Storage Container

Priority: 4

Description: Consider drum handling equipment requirements

Status: $\quad$ To be.resolved during training 
Item No.: $\quad 57$

Deviation: $\quad 8.6$ - Leak, Brine Concentrate Storage Container

Priority: 4

Description: Consider drum specification requirements

Status: $\quad$ To be resolved during training

Item No.: $\quad 58$

Deviation: $\quad 8.7$ - Rupture, Brine Concentrate Storage Container

Priority: 6

Description: Ventilation requirements

Status: Complete

Action: $\quad$ Fume vent added per DCN-01

Item No.: $\quad 59$

Deviation: $\quad 8.7$ - Rupture, Brine Concentrate Storage Container

Priority: 6

Description: Grounding requirements - electrical

Status: $\quad$ To be resolved during training

Item No.: $\quad 60$

Deviation: $\quad 8.7$ - Rupture, Brine Concentrate Storage Container

Priority: 6

Description: Class 1, Div. 1

Status: $\quad$ Complete

Action: Area will be ventilated

Item No.: $\quad 61$

Deviation: $\quad 9.2$ - High Flow, Waste Feed Return Line

Priority: 4

Description: Flow switch

Status: $\quad$ Complete

Action: $\quad$ Added per DCN-01

Item No.: $\quad 62$

Deviation: $\quad 9.2$ - High Flow, Waste Feed Return Line

Priority: 4

Description: Relocate pH meter (tank or pump suction before branch)

Status: $\quad$ Complete

Action: $\quad$ Moved per DCN-01

Item No.: 63

Deviation: $\quad 9.7$ - High Pressure, Waste Feed Return Line

Priority: 2

Description: Remove or lock open manual valve in return line

Status: $\quad$ Complete

Action: Done per $\mathrm{DCN}-01$ 
Item No.: 64

Deviation: 10.1 - High Flow, Evaporator Vapor Discharge Line

Priority: 6

Description: Add orifice between Evaporator and Oxidizer Heater

Status: $\quad$ Complete

Action: $\quad$ Done (FO 022-11)

Item No: $\quad 65$

Deviation: $\quad 10.1$ - High Flow, Evaporator Vapor Discharge Line

Priority: 6

Description: Investigate dynamic response of evaporator due to step change in back pressure

Status: $\quad$ Complete

Action: $\quad$ Effect is minimal

Item No.: $\quad 66$

Deviation: $\quad 10.3$ - Reverse Flow, Evaporator Vapor Discharge Line

Priority: 6

Description: Relocate startup Econobator air connection point

Status: $\quad$ Complete

Action: $\quad$ Propane removed per DCN-01

Item No: $\quad 67$

Deviation: $\quad 10.3$ - Reverse Flow, Evaporator Vapor Discharge Line

Priority: 6

Description: Interlock propane valve with low steam flow

Status: Complete

Action: Propane removed per DCN-01

Item No.: $\quad 68$

Deviation: $\quad 10.3$ - Reverse Flow, Evaporator Vapor Discharge Line

Priority: 6

Description: Consider ethanol instead of propane

Status: Complete

Action: $\quad$ Propane removed per DCN-01

Item No.: $\quad 69$

Deviation: $\quad 10.3$ - Reverse Flow, Evaporator Vapor Discharge Line

Priority: 6

Description: Interlock propane valve with negative differential between evaporator and point upstream of propane connection.

Status: $\quad$ Complete

Action: $\quad$ Propane removed per DCN-01

Item No.: $\quad 70$

Deviation: $\quad 10.3$ - Reverse Flow, Evaporator Vapor Discharge Line

Priority: 6

Description: Relocate propane injection point to downstream of heater

Status: Complete

Action: $\quad$ Propane removed per DCN-01 
Item No.: $\quad 71$

Deviation: $\quad 10.4$ - Misdirected Flow, Evaporator Vapor Discharge Line

Priority: 3

Description: Check valve

Status: $\quad$ Complete

Action: $\quad$ Propane removed per DCN-01

Item No.: $\quad 72$

Deviation: $\quad 10.4$ - Misdirected Flow, Evaporator Vapor Discharge Line

Priority: 3

Description: Interlock on low pressure in propane and/or air

Status: $\quad$ Complete

Action: $\quad$ Propane removed per DCN-01

Item No.: $\quad 73$

Deviation: $\quad 10.4$ - Misdirected Flow, Evaporator Vapor Discharge Line

Priority: 6

Description: Relocate propane line feed after oxidizer heater

Status: $\quad$ Complete

Action: $\quad$ Propane removed per $\mathrm{DCN}-01$

Item No.: $\quad 74$

Deviation: $\quad 10.5$ - High Temperature, Evaporator Vapor Discharge Line

Priority: 6

Description: Interlock differential pressure on Econobator with shutdown sequence

Status: $\quad$ Complete

Action: $\quad$ Propane removed per DCN-01

Item No: $\quad 75$

Deviation: $\quad 10.5$ - High Temperature, Evaporator Vapor Discharge Line

Priority: 6

Description: Correct valve $032-5$ to be fail open

Status: $\quad$ Complete

Action: Done per DCN-01

Item No.: $\quad 76$ (duplicate of Item 41)

Item No.: $\quad 77$

Deviation: $\quad 10.7$ - High Pressure, Evaporator Vapor Discharge Line

Priority: 7

Description: High pressure interlock to system shutdown

Status: Complete

Action: Interlock exists on top of evaporator 
Item No.: $\quad 78$

Deviation: $\quad 10.7$ - High Pressure, Evaporator Vapor Discharge Line

Priority: 7

Description: Route PSV discharge to safe location

Status: $\quad$ Complete

Action: $\quad$ Route to vent line

Item No.: $\quad 79$

Deviation: $\quad 10.7$ - High Pressure, Evaporator Vapor Discharge Line

Priority: 7

Description: Coordinate design pressure of steam, air, and process systems

Status: $\quad$ Complete

Action: $\quad$ Added PSV for air - not practical for steam

Item No.: $\quad 80$

Deviation: 10.9 - High Concentration of Contaminants, Evaporator Vapor Discharge Line

Priority: 5

Description: Remove vent line from waste feed tank

Status: $\quad$ Complete

Action: $\quad$ Line will be retained; redundant instrumentation to be added

Item No.: $\quad 81$

Deviation: $\quad 10.9$ - High Concentration of Contaminants, Evaporator Vapor Discharge Line

Priority: 5

Description: Calculate percent increase in feed rate allowed by SOP

Status: Complete

Action: $\quad$ Changes will be limited to $10 \%$

Item No.: $\quad 82$ (duplicate of Item 9)

Item No.: $\quad 83$

Deviation: 11.8 - High Process Flow, Oxidizer Heater

Priority: 4

Description: Add orifice or check valve size in propane line to limit maximum propane flow.

Status: $\quad$ Complete

Action: Propane removed per DCN-01

Item No.: $\quad 84$

Deviation: 11.8 - High Process Flow, Oxidizer Heater

Priority: 4

Description: Add high propane pressure interlock to propane valve and electric heater shutoff.

Status: Complete

Action: Propane removed per DCN-01

Item No.: $\quad 85$ (Duplicated by Item 95)

Deviation: $\quad 11.9$ - Low/No Process Flow, Oxidizer Heater

Priority: 8

Description: Delta temperature sensor interlocked to system shutdown at catalytic Econobator.

Status: $\quad$ Complete

Action: Will be covered by Item 86 
Item No.: $\quad 86$ (duplicated by Item 94)

Deviation: $\quad 11.9$ - Low/No Process Flow, Oxidizer Heater

Priority: 8

Description: High temperature shutoff at heater outlet and/or Econobator.

Status: Complete

Action: Interlock added per DCN-01

Item No.: $\quad 87$

Deviation: 11.9 - Low/No Process Flow, Oxidizer Heater

Priority: 8

Description: Move interlock 11 to heater outlet

Status: $\quad$ Complete

Action: $\quad$ Redundant due to Item 86

Item No.: $\quad 88$

Deviation: $\quad 11.9$ - Low/No Process Flow, Oxidizer Heater

Priority: 8

Description: Delta pressure sensor across Econobator.

Status: Complete

Action: No detonation (propane removed)

Item No.: $\quad 89$

Deviation: $\quad 11.12$ - Low Process Temperature, Oxidizer Heater

Priority: 4

Description: Spare heater

Status: $\quad$ To be resolved during training

Item No.: $\quad 90$

Deviation: $\quad 11.13$ - High Pressure, Oxidizer Heater

Priority: 6

Description: Rate system for up to $35 \mathrm{psig}$

Status: In progress

Comment: Waiting on Haynes data

Item No.: 91

Deviation: $\quad 11.13$ - High Pressure, Oxidizer Heater

Priority: 6

Description: Coordinate boiler pressure

Status: $\quad$ Complete

Action: $\quad$ Not practical (see item 79)

Item No.: $\quad 92$

Deviation: 11.15 - Tube Leak, Oxidizer Heater

Priority: 5

Description: Corrosion coupons

Status: In progress 
Item No.: 93

Deviation: $\quad 13.2$ - Low Flow, Catalytic Econobator

Priority: 1

Description: Hard-wired dP switch - safety shutdown

Status: $\quad$ Complete

Action: $\quad$ Software interlock in place per item 74

Item No.: 94 (duplicate of Item 86)

Item No.: 95 (duplicate of Item 85)

Item No:: $\quad 96$

Deviation: 13.5 - High Temperature, Catalytic Econobator

Priority: 6

Description: Econobator outlet temp hard wire shutdown (1450-1500)

Status: Complete

Action: $\quad$ Software interlock added per DCN-01

Item No: $\quad 97$

Deviation: $\quad 13.5$ - High Temperature, Catalytic Econobator

Priority: 6

Description: Process water pump failure interlock

Status: $\quad$ Complete

Action: Interlock added per DCN-01

Item No: $\quad 98$

Deviation: 13.11 - External Leak, Catalytic Econobator

Priority: 4

Description: Ambient $\mathrm{CO}$ monitor

Status: $\quad$ To be resolved during training

Item No.: 99

Deviation: $\quad 14.1$ - High Flow, Discharge Line from Econobator to Scrubber

Priority: 3

Description: Flow meter in quench liquid feed line

Status: $\quad$ Complete

Action: Quench deleted per DCN-01

Item No.: $\quad 100$

Deviation: $\quad 14.1$ - High Flow, Discharge Line from Econobator to Scrubber

Priority: 3

Description: Sodium hydroxide in quench feed line

Status: $\quad$ Complete

Action: Quench deleted per DCN-01 
Item No.: 101

Deviation: $\quad$ 14.1 - High Flow, Discharge Line from Econobator to Scrubber

Priority: $\quad 3$

Description: Check two-phase flow pressure drop in worst-case situation

Status: Complete

Action: Quench deleted per DCN-01

Item No.: 102

Deviation: $\quad 14.2$ - Low/No Flow, Discharge Line from Econobator to Scrubber

Priority: 6

Description: Flow meter on line 14 quench feed line

Status: $\quad$ Complete

Action: Quench deleted per DCN-01

Item No.: 103

Deviation: $\quad 14.2$ - Low/No Flow, Discharge Line from Econobator to Scrubber

Priority: 6

Description: Throttle valve on quench feed line

Status: $\quad$ Complete

Action: Quench deleted per DCN-01

Item No.: 104

Deviation: $\quad 14.2$ - Low/No Flow, Discharge Line from Econobator to Scrubber

Priority: 6

Description: High temperature indicator on drain line from quench

Status: $\quad$ Complete

Action: Quench deleted per DCN-01

Item No.: $\quad 105$

Deviation: $\quad 14.2$ - Low/No Flow, Discharge Line from Econobator to Scrubber

Priority: 6

Description: Quench with water only

Status: Complete

Action: Quench deleted per DCN-01

Item No.: 106

Deviation: $\quad 14.3$ - Reverse Flow, Discharge Line from Econobator to Scrubber

Priority: 7

Description: Make two-phase line large diameter

Status: $\quad$ Complete

Action: Quench deleted per DCN-01

Item No.: 107

Deviation: $\quad 14.5$ - High Temperature, Discharge Line from Econobator to Scrubber

Priority: 3

Description: Spiral heat exchanger / indirect cooling

Status: $\quad$ Complete

Action: Heat exchanger will be added

Item No.: 108 
Deviation: $\quad 14.10$ - External Leak, Discharge Line from Econobator to Scrubber

Priority: 7

Description: Corrosion coupons

Status: In progress

Item No.: 109

Deviation: $\quad 15.1$ - High Flow, Packed-Bed Scrubber

Priority: 3

Description: Stock HEPA filters

Status: $\quad$ To be resolved during training

Item No.: 110 (duplicated by Items 130 and 131)

Deviation: $\quad 15.1$ - High Flow, Packed-Bed Scrubber

Priority: 3

Description: Mercury recovery unit

Status: $\quad$ To be resolved during training

Comment: Mercury wastes will be excluded or handled case-by-case

Item No. 111

Deviation: $\quad 15.1$ - High Flow, Packed-Bed Scrubber

Priority: 3

Description: Show mist eliminator on P\&ID

Status: Complete

Action: Mist eliminator added per DCN-01

Item No.: 112

Deviation: $\quad 15.2$ - Low/No Flow, Packed-Bed Scrubber

Priority: 5

Description: Insulate process lines up to and including scrubber

Status: $\quad$ Complete

Action: Done

Item No.: 113

Deviation: $\quad 15.2$-Low/No Flow, Packed-Bed Scrubber

Priority: 5

Description: Delta P and water wash on mist eliminator

Status: Complete

Action: $\quad \mathrm{dP}$ across packing and demister is adequate

Item No.: 114

Deviation: $\quad 15.2$-Low/No Flow, Packed-Bed Scrubber

Priority: 5

Description: Show insulation on P\&ID

Status: Complete

Action: Done 
Item No:: 115 (duplicated by Item 42)

Deviation: $\quad 15.5$ - High Temperature, Packed-Bed Scrubber

Priority: 6

Description: High interlock to shut system down and water dump into scrubber

Status: $\quad$ Complete

Action: Use temperature signal from desuperheater (107), general shutdown

Item No.: $\quad 116$

Deviation: $\quad 15.8$ - Low Reaction Rate, Packed-Bed Scrubber

Priority: 7

Description: Spares

Status: In progress

Item No.: $\quad 117$

Deviation: $\quad 15.13$ - High Level, Packed-Bed Scrubber

Priority: 5

Description: Add high delta $\mathrm{P}$ alarm at scrubber bed

Status: $\quad$ Complete

Action: Done

Item No.: 118 (duplicated by Item 119)

Deviation: $\quad 15.13$ - High Level, Packed-Bed Scrubber

Priority: 5

Description: High level gauge in scrubber (sight glass)

Status: $\quad$ Complete

Action: $\quad$ Added per $\mathrm{DCN} \_01$

Item No.: 119 (duplicate of Item 118)

Item No.: $\quad 120$

Deviation: $\quad 15.14$ - Low Level, Packed-Bed Scrubber

Priority: 6

Description: Manual or high quality auto blowdown valve

Status: $\quad$ Complete

Action: Selected valve is high quality

Item No.: 121

Deviation: $\quad 15.14$ - Low Level, Packed-Bed Scrubber

Priority: 6

Description: City water supply to quench

Status: Complete

Action: Quench deleted per DCN-01

Item No.: 122

Deviation: $\quad 15.14$ - Low Level, Packed-Bed Scrubber

Priority: 6

Description: Make distillate for makeup water

Status: Complete

Action: Use of condenser reviewed and rejected 
Item No.: 123

Deviation: $\quad 16.1$ - High Flow, Process Vent Line from Scrubber

Priority: 3

Description: Oversize HEPA filter

Status: $\quad$ Complete

Action: Will be done

Item No.: 124

Deviation: $\quad 16.5$ - High Temperature, Process Vent Line from Scrubber

Priority: $\quad 3$

Description: Add heat tracing indication to P\&ID

Status: Complete

Action: $\quad$ Added per DCN-01

Item No.: 125

Deviation: $\quad 16.5$ - High Temperature, Process Vent Line from Scrubber

Priority: 3

Description: High temperature to trace control

Status: $\quad$ Complete

Action: Use self-limiting heat tape

Item No.: 126

Deviation: $\quad 16.5$ - High Temperature, Process Vent Line from Scrubber

Priority: 3

Description: Use self-limiting heat trace tape

Status: $\quad$ Complete

Action: $\quad$ Alternative to Item 125

Item No.: 127

Deviation: $\quad 16.6$ - Low Temperature, Process Vent Line from Scrubber

Priority: 1

Description: HEPA filter higher than scrubber discharge

Status: $\quad$ Complete

Action: $\quad$ Note added to P\&ID

Item No.: $\quad 128$

Deviation: $\quad$ 16.7 - High Pressure, Process Vent Line from Scrubber

Priority: 2

Description: Delete carbon drum

Status: $\quad$ Complete

Action: Drum deleted per DCN-01

Item No.: $\quad 129$

Deviation: $\quad 16.7$ - High Pressure, Process Vent Line from Scrubber

Priority: 2

Description: Lock valve open

Status: Complete

Action: Done per DCN-01

Item No.: 130 (duplicate of Item 110) 
Item No.: 131 (duplicate of Item 110)

Item No.: 132

Deviation: $\quad 17.1$ - High Flow, Scrubber Liquid Recirculation Line

Priority: 3

Description: Add recirculation throttle valve

Status: $\quad$ Complete

Action: $\quad$ Not needed since quench eliminated

Item No.: 133

Deviation: $\quad 17.1$ - High Flow, Scrubber Liquid Recirculation Line

Priority: 3

Description: Design pump to deliver only max allowable flow

Status: $\quad$ Complete

Action: $\quad$ Valve in process line will balance flow on startup

Item No.: 134

Deviation: $\quad 17.2$ - Low/No Flow, Scrubber Liquid Recirculation Line

Priority: 6

Description: High delta $\mathrm{P}$ across packing interlock to shutdown unit

Status: Complete

Action: Interlocks elsewhere will shut down unit

Item No.: $\quad 135$

Deviation: $\quad 17.5$ - High Temperature, Scrubber Liquid Recirculation Line

Priority: None listed

Description: Add insulation to P\&ID

Status: $\quad$ Complete

Action: Done

Item No.: 136 (duplicated by Item 140)

Deviation: $\quad 17.8$ - Low Pressure, Scrubber Liquid Recirculation Line

Priority: 5

Description: Blowdown valve manual

Status: : $\quad$ Complete

Action: $\quad$ Selected valve is high quality

Item No.: 137

Deviation: $\quad 17.9$ - High Concentration of Contaminants, Scrubber Liquid Recirculation Line

Priority: 4

Description: Corrosion coupons

Status: In progress

Item No.: 138 (duplicated by Item 143)

Deviation: $\quad 17.10$ - External Leak, Scrubber Liquid Recirculation Line

Priority: 5

Description: Teflon-lined pipe and scrubber

Status: $\quad$ To be resolved during training

Item No.: 139 
Deviation: $\quad 17.10$ - External Leak, Scrubber Liquid Recirculation Line

Priority: 5

Description: Magnetic drive pump

Status: Complete

Action: Use double mechanical seals

Item No.: 140 (duplicate of Item 136)

Item No:: $\quad 141$

Deviation: $\quad 18.1$ - High Flow, Scrubber Liquid Recirculation Line

Priority: 7

Description: Load cell on scrubber blowdown tank

Status: Complete

Action: Done

Item No.: 142

Deviation: $\quad 19.3$ - High Level, Scrubber Blowdown Storage Container

Priority: 7

Description: Operating procedures

Status: $\quad$ To be resolved during training

Item No.: 143 (duplicate of Item 138)

Item No.: $\quad 144$

Deviation: $\quad 20.1$ - High Flow, Propane Feed Line

Priority: 6

Description: Orifice to limit max propane feed

Status: $\quad$ Complete

Action: $\quad$ Propane removed per DCN-01

Item No.: 145

Deviation: $\quad 20.1$ - High Flow, Propane Feed Line

Priority: 6

Description: Change from propane to some other fuel

Status: $\quad$ Complete

Action: $\quad$ Propane removed per DCN-01

Item No.: 146

Deviation: $\quad 20.1$ - High Flow, Propane Feed Line

Priority: 6

Description: Pressure switch or relief valve in propane line

Status: Complete

Action: Propane removed per DCN-01

Item No.: $\quad 147$

Deviation: $\quad 20.1$ - High Flow, Propane Feed Line

Priority: 6

Description: Set minimum air rate to insure mixture below LEL

Status: Complete

Action: $\quad$ Propane removed per DCN-01 
Item No.: $\quad 148$

Deviation: $\quad 20.3$ - Reverse Flow, Propane Feed Line

Priority: 3

Description: Spring type check valve

Status: Complete

Action: Propane removed per DCN-01

Item No.: 149 (duplicated by Item 155)

Deviation: $\quad 21.6$ - Low Temperature, Sodium Hydroxide Feed Line

Priority: 1

Description: Use diluted sodium hydroxide

Status: $\quad$ Complete

Action: Use $50 \% \mathrm{NaOH}$ with careful piping and drum location

Item No.: $\quad 150$

Deviation: $\quad$ 21.7 - High Pressure, Sodium Hydroxide Feed Line

Priority: 3

Description: Pump selection (deadhead pressure less than maximum line pressure)

Status: In progress

Comment: Will be confirmed and documented

Item No.: 151

Deviation: $\quad 21.10$ - External Leak, Sodium Hydroxide Feed Line

Priority: 3

Description: Welded lines (sodium hydroxide)

Status: Complete

Action: Will use tubing rated for adequate pressure

Item No.: 152

Deviation: $\quad 22.1$ - High Flow, Sulfuric Acid Feed Line

Priority: 3

Description: Add chemical feed descriptions to P\&ID

Status: Complete

Action: $\quad$ Added per DCN-01

Item No.: 153 (duplicate of Item 15)

Item No.: 154 (duplicate of Item 15)

Item No.: 155 (duplicate of Item 149)

Item No.: 156 (duplicate of Item 15)

Item No.: 157 (duplicate of Item 15) 
Item No.: 158

Deviation: $\quad 23.3$ - Reverse Flow, Vent Line from Feed Tank to Evaporator

Priority: 2

Description: Remove check valve

Status: Complete

Action: Check valve will be retained

Item No.: $\quad 159$

Deviation: $\quad 23.5$ - High Temperature, Vent Line from Feed Tank to Evaporator

Priority: 1

Description: Slope line towards evaporator.

Status: $\quad$ Complete

Action: $\quad$ Added to P\&ID

\section{C.3 Hazard Identification and Evaluation}

The eight postulated accident scenarios chosen in this PHA follow the roadmap presented in "Guidance for Preparation of the MWT Process Hazards Analysis" (DOE 1995b). Binning of these scenarios used the maximum likely MAR, and each was evaluated for possible consequences to the public, co-located worker, worker, and environment. All eight scenarios resulted in no public or environmental risk as shown in Table C.3-1; however co-located worker and worker risks are summarized below. Fault trees were produced for those accident scenarios with consequence ratings of $\mathrm{A}, \mathrm{B}$, or $\mathrm{C}$ (refer to Table C.4-1).

\section{Initiating Event 1}

Spark when drum handling resulting in a fire.

Worker-may receive moderate exposure with minor health effects/injuries

1. radiological contamination-dermal/inhalation

2. chemical exposure-dermal/inhalation

\section{Initiating Event 2}

Exterior rupture of feed tank resulting in a fire.

Co-located worker-may incur a low exposure with negligible health effects

Worker-The worker may incur a significant exposure and associated health effects with the possibility of severe injury but no permanent disability.

1. burns-possible hospitalization

2. chemical exposure-dermal/inhalation

3. radiological contamination-dermal/inhalation

\section{Initiating Event 3}

Interior rupture of feed tank resulting in a fire.

Worker-may incur a moderate exposure with minor injury/health effects

1. radiological contamination-dermal/inhalation

2. chemical exposure-dermal/inhalation 


\section{Initiating Event 4}

Exterior rupture of evaporator or evaporator leak, with ignition source, resulting in a fire.

Co-located worker-may incur a low exposure with negligible health effects

Worker-may incur a moderate exposure with minor injury/health effects

1. radiological contamination - dermal/inhalation

2. chemical exposure-dermal/inhalation

\section{Initiating Event 5}

Ethanol loss of containment with ignition source, resulting in a fire.

Co-located worker-may incur a significant exposure and health effects.

1. burns-possible hospitalization

2. chemical exposure-inhalation

Worker-may incur a potentially lethal/IDLH exposure.

1. severe burns-hospitalization

2. chemical exposure-dermal/inhalation

\section{Initiating Event 6}

A. Econobator loss of containment resulting in a $1200{ }^{\circ} \mathrm{F}$ steam release.

Co-located worker-may incur a high exposure with major health effects.

1. burns

2. chemical exposure-inhalation

Worker-may incur a potentially lethal exposure.

1. severe burns-hospitalization

2. chemical exposure-inhalation

B. Econobator loss of containment resulting in a release of $250^{\circ} \mathrm{F}$ steam with possible $\mathrm{CO}$ and/or $\mathrm{NO}_{\mathbf{x}}$.

Co-located worker-may incur moderate exposure with minor health effects.

1. chemical exposure-inhalation

Worker-may incur high exposure with major health effects and severe injury but no permanent disability.

1. burns-possible hospitalization

2. chemical exposure - inhalation 


\section{Initiating Event 7}

A. Sulfuric acid spill or release.

Co-located worker-may incur low exposure and negligible health effects .

Worker-may incur moderate exposure and minor injury/health effects.

1. chemical exposure-dermal/inhalation

B. Sodium hydroxide spill or release.

Co-located worker-may incur a moderate exposure with minor health effects.

1. chemical exposure-inhalation

Worker-May incur a significant exposure and health effects with possible severe injury but no permanent disability.

1. burns-possible hospitalization

2. chemical exposure-dermal/inhalation

C. Acid/base reaction from spill or release and combination of the two.

Co-located worker-may incur a low exposure and negligible health effects.

Worker-may incur a significant exposure and health effects with possible severe injury but no permanent disability.

1. burns-possible hospitalization

2. chemical exposure-dermal/inhalation

\section{Initiating Event 8}

Brine scrubber blowdown release or spill.

Co-located worker-may incur a low exposure with negligible health effects.

Worker-may incur a moderate exposure with minor health effects and minor injury.

1. radiological contamination-dermal

These events and their consequences are summarized in Table C.3-1.

Table C.3-1. Accident Initiating Event Binning

\begin{tabular}{|c|l|c|c|c|c||}
\hline \multicolumn{7}{|c|}{ Accident Initiating Event Binning - Using Maximum Likely MAR } \\
\hline $\begin{array}{c}\text { Event } \\
\text { Number }\end{array}$ & \multicolumn{1}{|c|}{ Initiating Events } & Public & $\begin{array}{c}\text { Co-Located } \\
\text { Worker }\end{array}$ & Worker & Environment \\
\hline 1 & Spark at drum being unloaded - Fire & None & None & D & None \\
\hline 2 & Ruptured exterior of feed tank - Fire & None & D & C & None \\
\hline 3 & Ruptured interior of feed tank - Fire & None & None & D & None \\
\hline 4 & Evaporator loss of containment - Fire & None & D & D & None \\
\hline 5 & Ethanol loss of containment - Release & None & B & A & None \\
\hline
\end{tabular}


Table C.3-1 (continued). Accident Initiating Event Binning

\begin{tabular}{|c|l|c|c|c|c||}
\hline \multicolumn{2}{|c|}{ Accident Initiating Event Binning - Using Maximum Likely MAR } \\
\hline $\begin{array}{c}\text { Event } \\
\text { Number }\end{array}$ & \multicolumn{1}{|c|}{ Initiating Events } & Public & $\begin{array}{c}\text { Co-Located } \\
\text { Worker }\end{array}$ & Worker & Environment \\
\hline $\mathbf{6}(\mathrm{a})$ & $\begin{array}{l}\text { Econobator loss of containment - a) Steam } \\
-1,200^{\circ} \mathrm{F} \text { (large) }\end{array}$ & None & A & B & None \\
\hline $\mathbf{6}$ (b) & $\begin{array}{l}\text { Econobator loss of containment - b) CO } \\
\text { and/or NO } \text { release (small) }\end{array}$ & None & C & B & None \\
\hline 7 (a) & $\begin{array}{l}\text { Process liquid spill or release - a) Sulfuric } \\
\text { Acid (5-gal) }\end{array}$ & None & D & D & None \\
\hline 7 (b) & $\begin{array}{l}\text { Process liquid spill or release - b) Sodium } \\
\text { Hydroxide (55-gal) }\end{array}$ & None & C & C & None \\
\hline 7 (c) & $\begin{array}{l}\text { Process liquid spill or release - c) Reaction } \\
\text { between a and b }\end{array}$ & None & D & C & None \\
\hline 8 & $\begin{array}{l}\text { Breach of Brine container - Release } \\
\text { Scrubber Blowdown - overflow of container }\end{array}$ & None & D & D & None \\
\hline
\end{tabular}

The hazard consequences (A through D) listed in Table C.3-1 are defined in Table C.4-1 with hazard consequence $\mathrm{A}$ being the most severe.

\section{C.4 Design Basis Accident Analysis Scenarios for Selected Accidents (Fault Trees)}

Postulated accident scenarios from Table C.3-1 that had consequence ratings of A, B, or C as described in Table C.4-1 were further studied to estimate their frequency according to the guidelines in Table C.4-2. The estimated consequence and severity ratings were combined to generate an overall risk ranking using the risk matrix from Table C.4-3. The decision criteria that were followed in action item resolution are identified in Table C.4-4. This PHA formally addresses only the safety risks, although action items from all risk categories were resolved.

Table C.4-1. Consequence Categories

\begin{tabular}{||c|l|c|l|l||}
\hline \multicolumn{5}{|c|}{ Consequences Severity Categories } \\
\hline Category & \multicolumn{4}{|c||}{ Maximum Possible Consequences } \\
\cline { 2 - 5 } & \multicolumn{1}{|c|}{ Public } & \multicolumn{1}{c|}{ Co-Located } & \multicolumn{1}{c||}{ Worker } & Environment \\
\hline $\begin{array}{c}\text { A } \\
\text { High }\end{array}$ & $\begin{array}{l}\text { Significant public } \\
\text { exposure with significant } \\
\text { health effects }\end{array}$ & $\begin{array}{l}\text { High co-located worker } \\
\text { exposure with major } \\
\text { health effects }\end{array}$ & $\begin{array}{l}\text { Potentially lethal worker } \\
\text { exposure, loss of life } \\
\text { from energy release }\end{array}$ & $\begin{array}{l}\text { Significant onsite and } \\
\text { offsite contamination }\end{array}$ \\
\hline $\begin{array}{c}\text { B } \\
\text { Moderate }\end{array}$ & $\begin{array}{l}\text { Moderate exposure with } \\
\text { minor health effects }\end{array}$ & $\begin{array}{l}\text { Significant exposure with } \\
\text { significant health effects }\end{array}$ & $\begin{array}{l}\text { High exposure with } \\
\text { major health effects, } \\
\text { severe injury }\end{array}$ & $\begin{array}{l}\text { Significant onsite and } \\
\text { minor offsite } \\
\text { contamination. }\end{array}$ \\
\hline $\begin{array}{c}\text { Cow } \\
\text { Low exposure with } \\
\text { negligible health effects }\end{array}$ & $\begin{array}{l}\text { Moderate exposure with } \\
\text { minor health effects }\end{array}$ & $\begin{array}{l}\text { Significant exposure } \\
\text { with significant health } \\
\text { effects, severe injury but } \\
\text { no disability }\end{array}$ & $\begin{array}{l}\text { Significant facility } \\
\text { contamination }\end{array}$ \\
\hline $\begin{array}{c}\text { D } \\
\text { Negligible }\end{array}$ & $\begin{array}{l}\text { Negligible exposure with } \\
\text { no health effects }\end{array}$ & $\begin{array}{l}\text { Low exposure with } \\
\text { negligible heath effects }\end{array}$ & $\begin{array}{l}\text { Moderate exposure with } \\
\text { minor health effects, } \\
\text { minor injury }\end{array}$ & $\begin{array}{l}\text { Minor facility } \\
\text { contamination }\end{array}$ \\
\hline
\end{tabular}




\section{Table C.4-2. Frequency Categories}

\begin{tabular}{||c|l|}
\hline \multicolumn{2}{|c|}{ Frequency (Likelihood) Categories } \\
\hline I $(>0.1)$ & Normal operations; once per month \\
\hline II $(0.1$ to 0.01$)$ & Anticipated Events; once per waste stream \\
\hline III $\left(10^{-2}\right.$ to $\left.10^{-4}\right)$ & Unlikely; once per site visit \\
\hline IV $\left(10^{-4}\right.$ to $\left.10^{-6}\right)$ & Very likely; once in the life of the mobile treatment unit \\
\hline V & Improbable; impossible \\
\hline
\end{tabular}

Note: Frequencies determined specifically for the MTU, based on equipment life.

Table C.4-3. Risk Rank Matrix

\begin{tabular}{|c|c|c|c|c|c|}
\hline \multicolumn{6}{|c|}{ Risk Rank Matrix } \\
\hline $\begin{array}{c}\text { Consequence } \\
\text { Category }\end{array}$ & \multicolumn{5}{|c|}{ Frequency Category } \\
\cline { 2 - 7 } & I & II & III & IV & V \\
\hline A & 1 & 1 & 1 & 2 & 3 \\
\hline B & 1 & 1 & 2 & 3 & 4 \\
\hline C & 1 & 2 & 3 & 4 & 4 \\
\hline D & 2 & 3 & 4 & 4 & 4 \\
\hline
\end{tabular}

Table C.4-4. Risk Decision Criteria

\begin{tabular}{|c|l|}
\hline \multicolumn{2}{|c|}{ Risk Decision Criteria } \\
\hline Risk Number & \multicolumn{1}{|c|}{ Accepted Action } \\
\hline 1 & Unacceptable Risk - Must be mitigated to risk number 3 or lower \\
\hline 2 & Undesirable Risk - Should be reduced to risk rank 3 or lower with cost enhancements \\
\hline 3 & Acceptable With Controls - Should evaluate cost effective enhancements \\
\hline 4 & Acceptable As is - No action necessary \\
\hline
\end{tabular}

\section{Scenario 1-Natural Phenomenon (Figure C.4-1)}

Failures due to a natural phenomenon were limited to initiation by earthquake. High wind, flooding, temperature extremes, and others were not considered because it is assumed that the MTU will be housed in a RCRA-permitted building which would be designed for these considerations. Tornados and cyclones are not expected at the sites this MTU is serving. 


\section{Scenario 2-Ethanol Fire (Figures C.4-2 and C.4-3)}

\section{Major Ethanol Fire (Figure C.4-2)}

A major ethanol fire could result from a loss of containment of the ethanol in conjunction with the presence of oxygen and a spark. Loss of containment could result if the ethanol container were dropped or punctured by maintenance equipment or if it tipped over and hit a sharp corner. The frequency of IV with a consequence of $A$ to the worker and $B$ to the co-located worker give a risk rank of 2.

\section{Minor Ethanol Fire (Figure C.4-3)}

A minor ethanol fire could occur if the fittings were improperly installed or were defective, causing a slow leak from the ethanol supply. Minor physical damage to the ethanol container could also produce a small loss of containment of ethanol. Should a spark occur in these conditions, a minor fire involving the ethanol spill could result. A frequency of IV with potential lethal consequences to the worker and potential high exposure to the co-located worker (Consequence Category A and B) results in a risk of 2 or 3.

\section{Scenario 3-Personnel Injury from Steam Release (Figures C.4-4 through C.4-5)}

\section{Steam Fatality (Figure C.4-4)}

Loss of containment on the $1,200^{\circ} \mathrm{F}$ or $250^{\circ} \mathrm{F}$ steam due to physical damage to the Econobator or associated piping could result in a steam fatality if personnel were in close contact with the steam. Release of high temperature steam is not visibly recognizable, which presents an additional degree of risk. A release of $1,200^{\circ} \mathrm{F}$ steam has a frequency of $\mathrm{V}\left(10^{-7}\right)$ with consequences to the worker and-a co-located worker rated $\mathrm{C}$. The overall risk rank is 4 .

\section{Chronic Steam Release (Figure C.4-5)}

A slow leak in the steam piping could also present the potential for burns to workers should piping be damaged during operation or maintenance. The frequency rating of IV and consequence ratings of $B$ to the worker and $\mathrm{C}$ to the co-located worker result in a risk ranking of 3 and 4.

\section{Scenario 4-Personnel Injury from Exposure (Figures C.4-6 through C.4-8)}

Loss of containment for the sulfuric acid or sodium hydroxide could result in exposure to the worker resulting in low to moderate health effects. Should both materials suffer a loss of containment at once and were in close enough proximity to mix, an additional hazard is presented. These three event trees show those accidents and estimate the risks.

\section{Personnel Injury from Exposure from Sulfuric Acid Loss of Containment (Figure C.4-6)}

Sulfuric acid loss of containment results in an exposure consequence $\mathrm{D}$ to the worker and co-located worker and a frequency of IV. The risk ranking is 4.

\section{Personnel Injury from Exposure from Sodium Hydroxide Loss of Containment (Figure C.4-7)}

Sodium hydroxide loss of containment could result in an exposure consequence $\mathrm{C}$ to both the worker and co-located worker and a frequency of IV. The risk ranking is 4 . 


\section{Personnel Injury from Chemical Loss of Containment Reaction (Figure C.4-8)}

Concurrent sulfuric acid and sodium hydroxide loss of containment that are in close proximity could cause a chemical reaction producing fumes to expose the worker and co-located worker. The consequence category $\mathrm{C}$ to the worker and $\mathrm{D}$ to the co-located combined with the frequency of $\mathrm{V}$ determines a risk rank of 4 . 


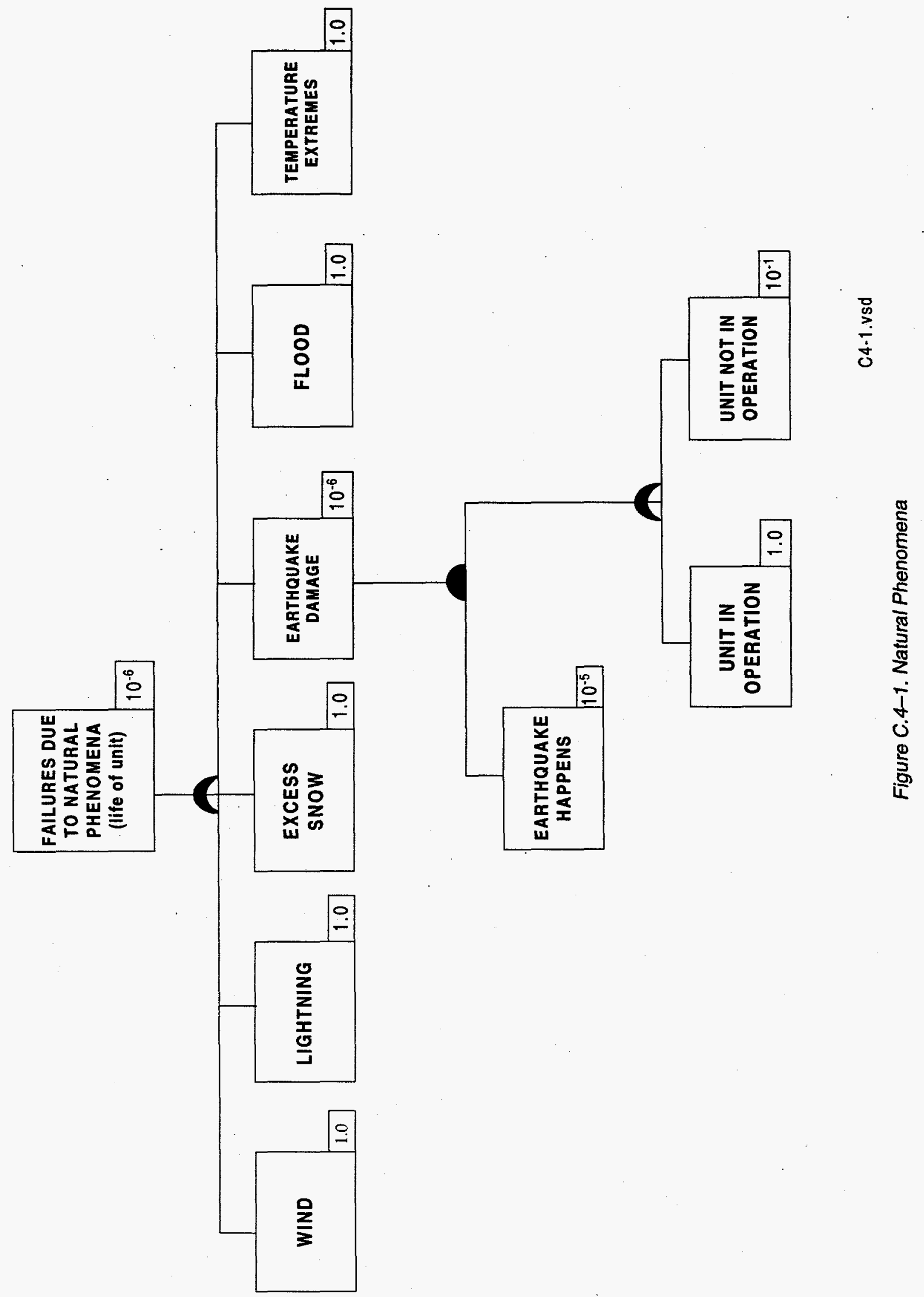




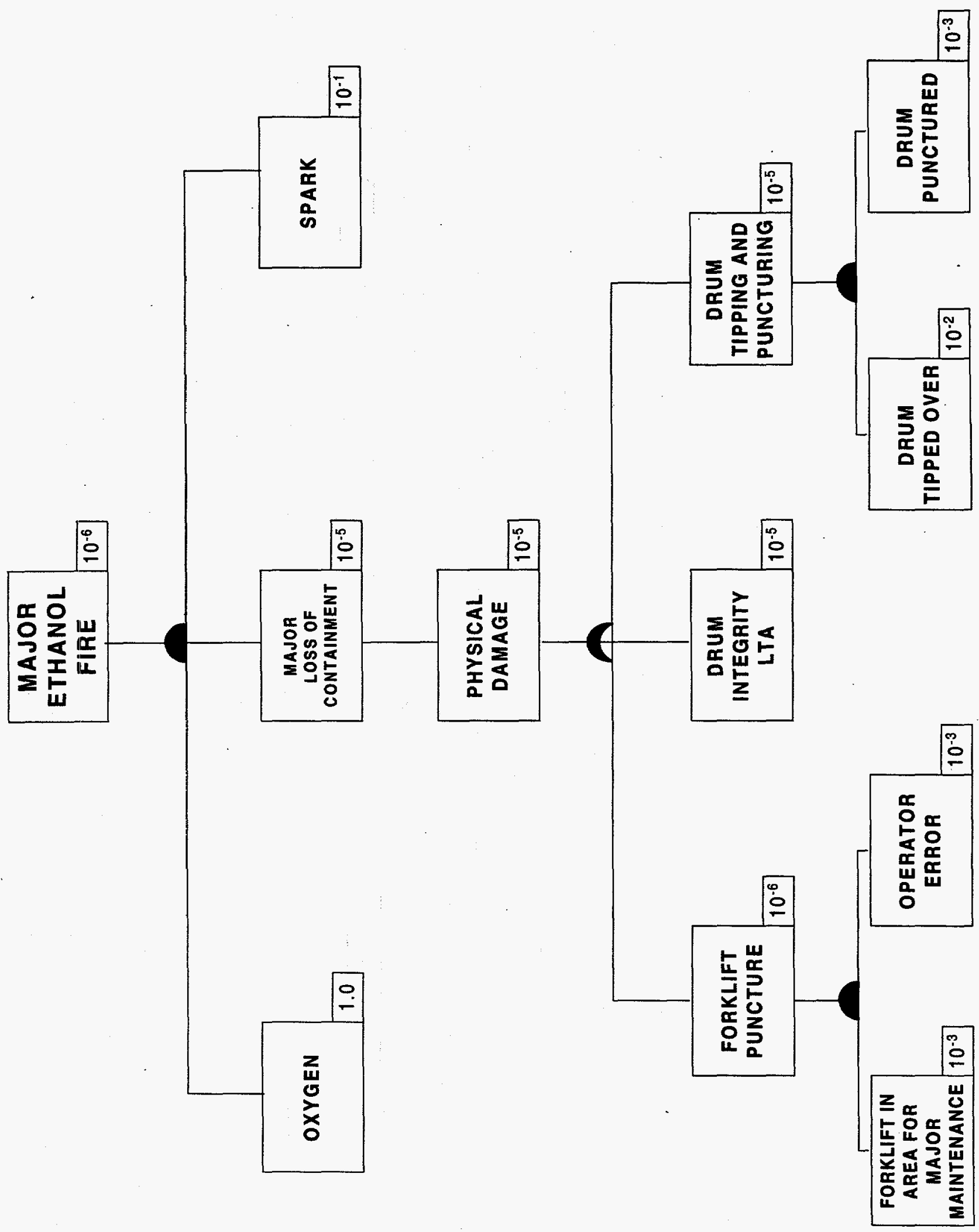




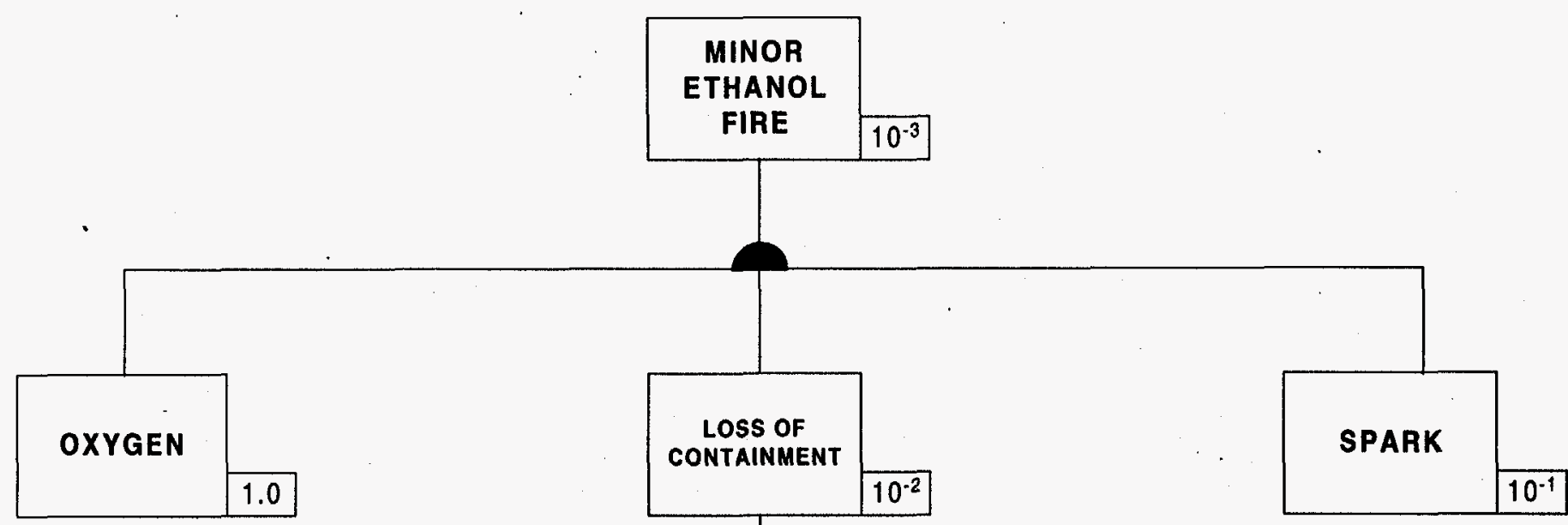

Figure C.4-3. Minor Ethanol Fire 


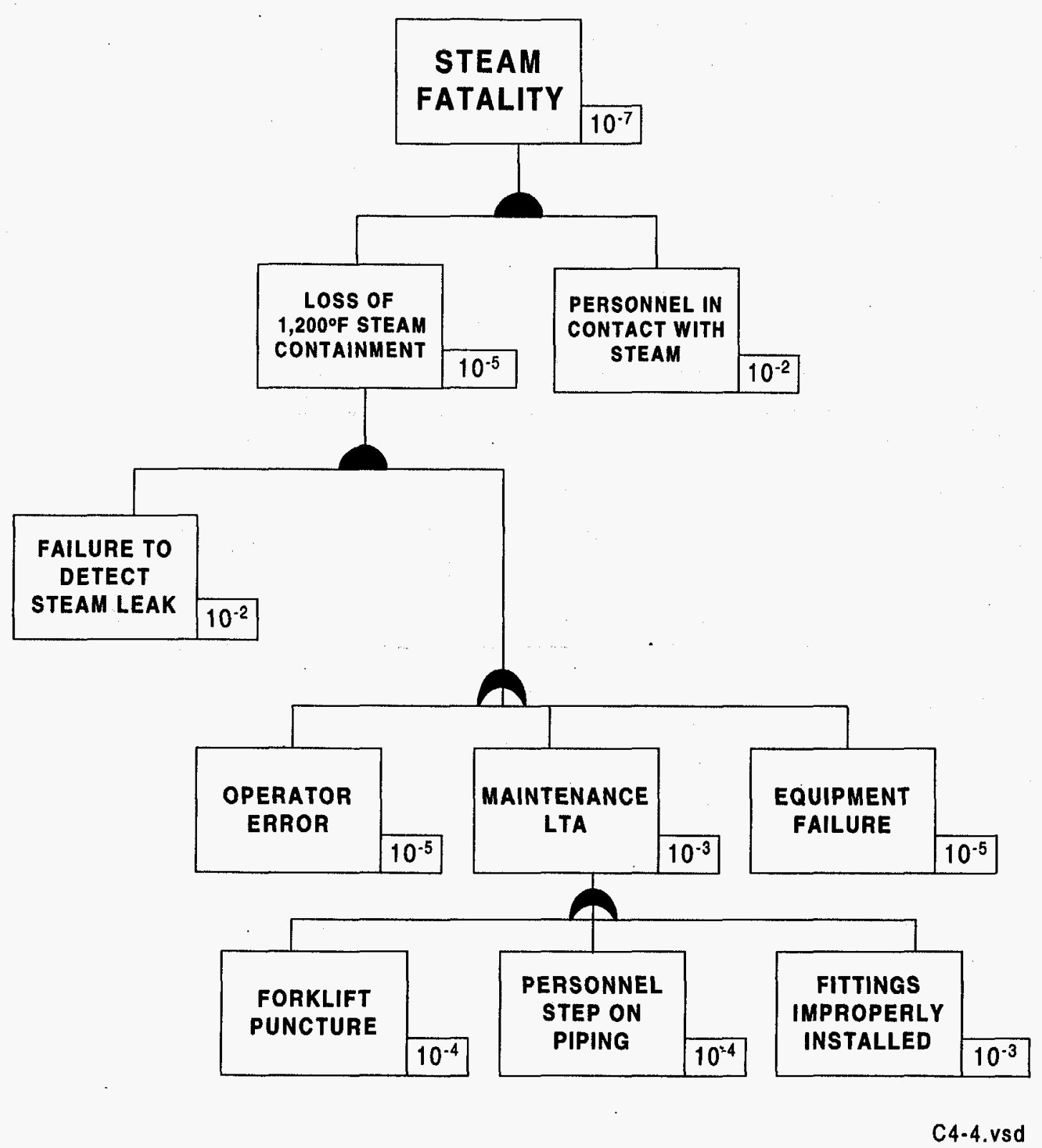

Figure C.4-4. Steam Fatality 


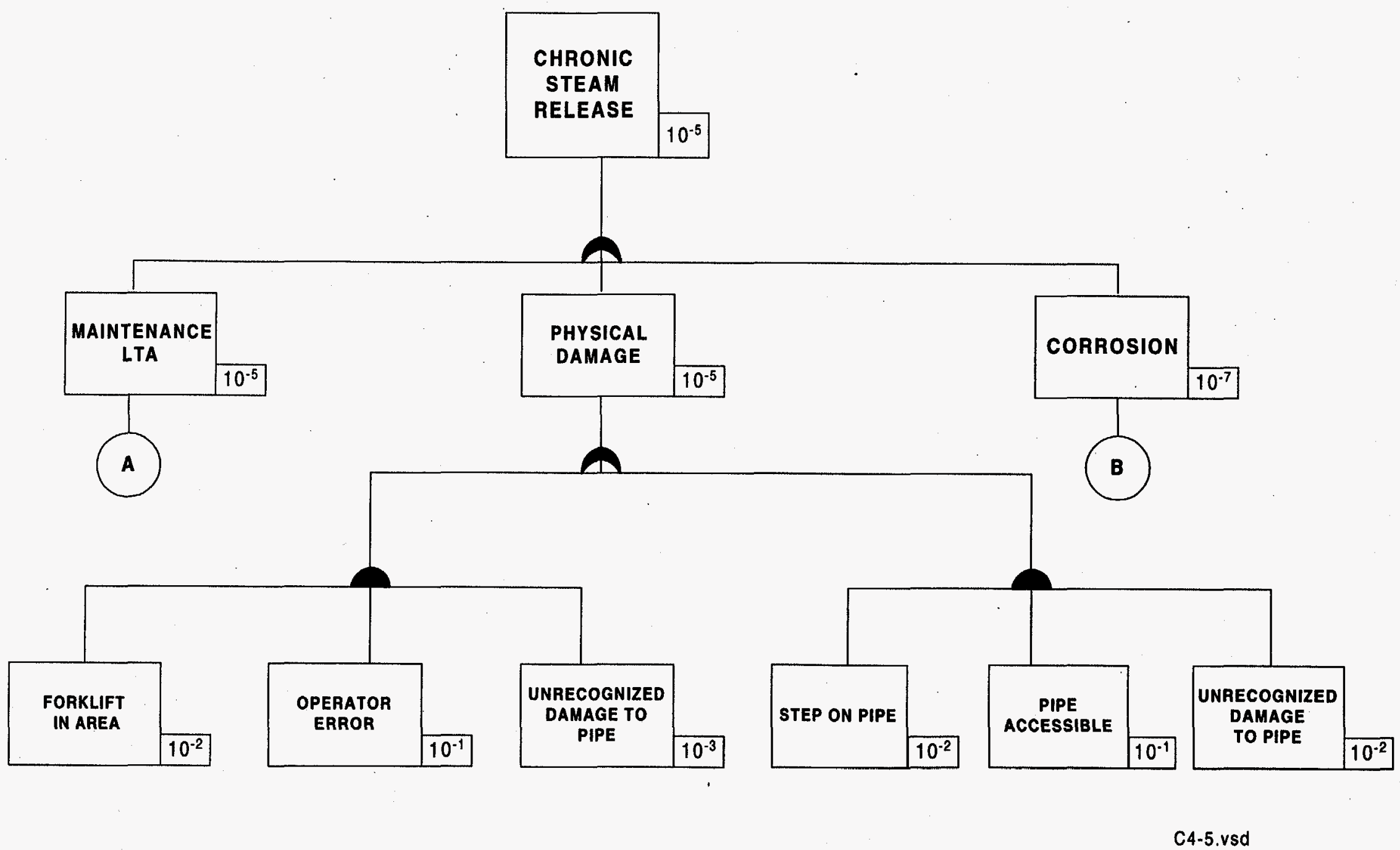

Figure C.4-5. Chronic Steam Release 


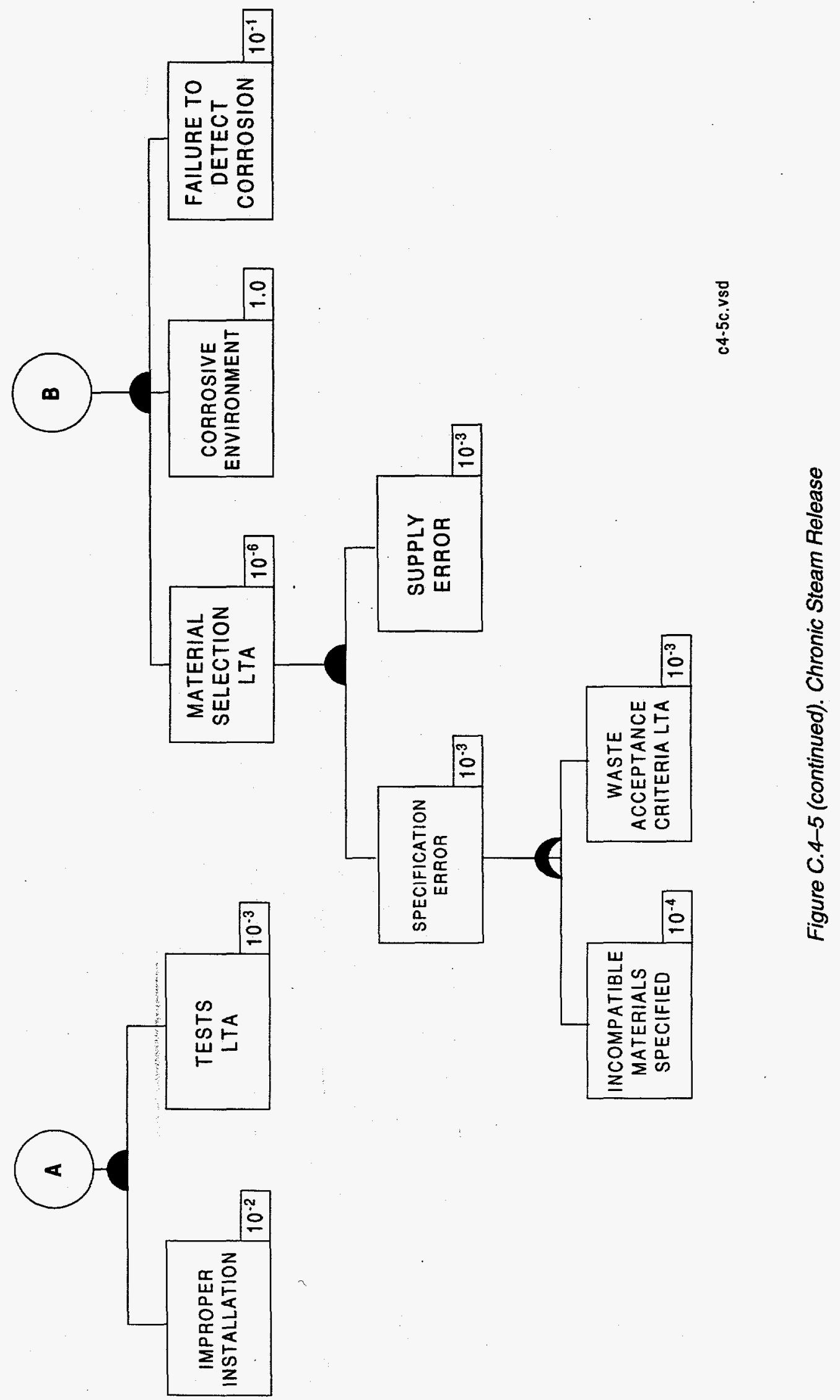




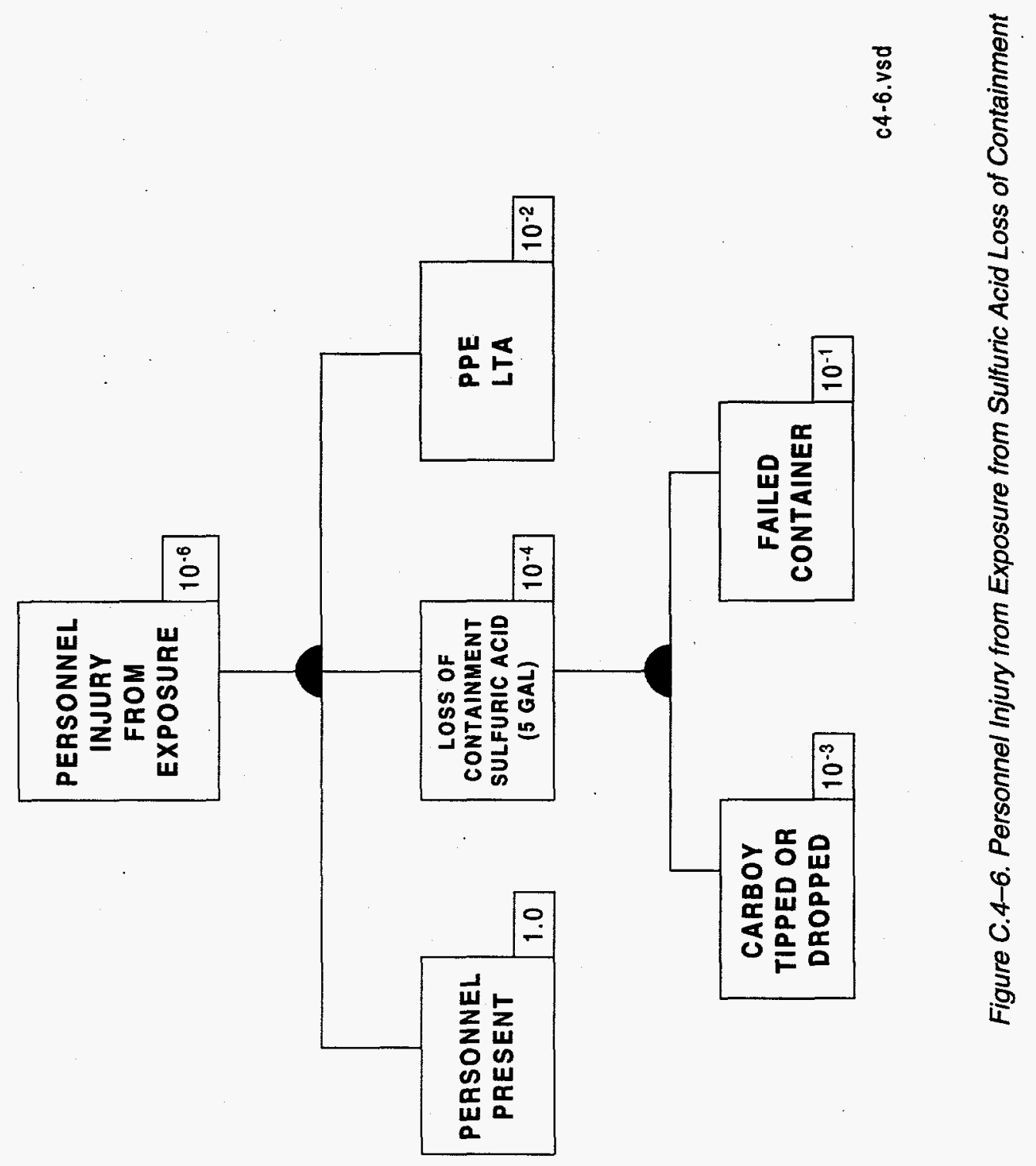




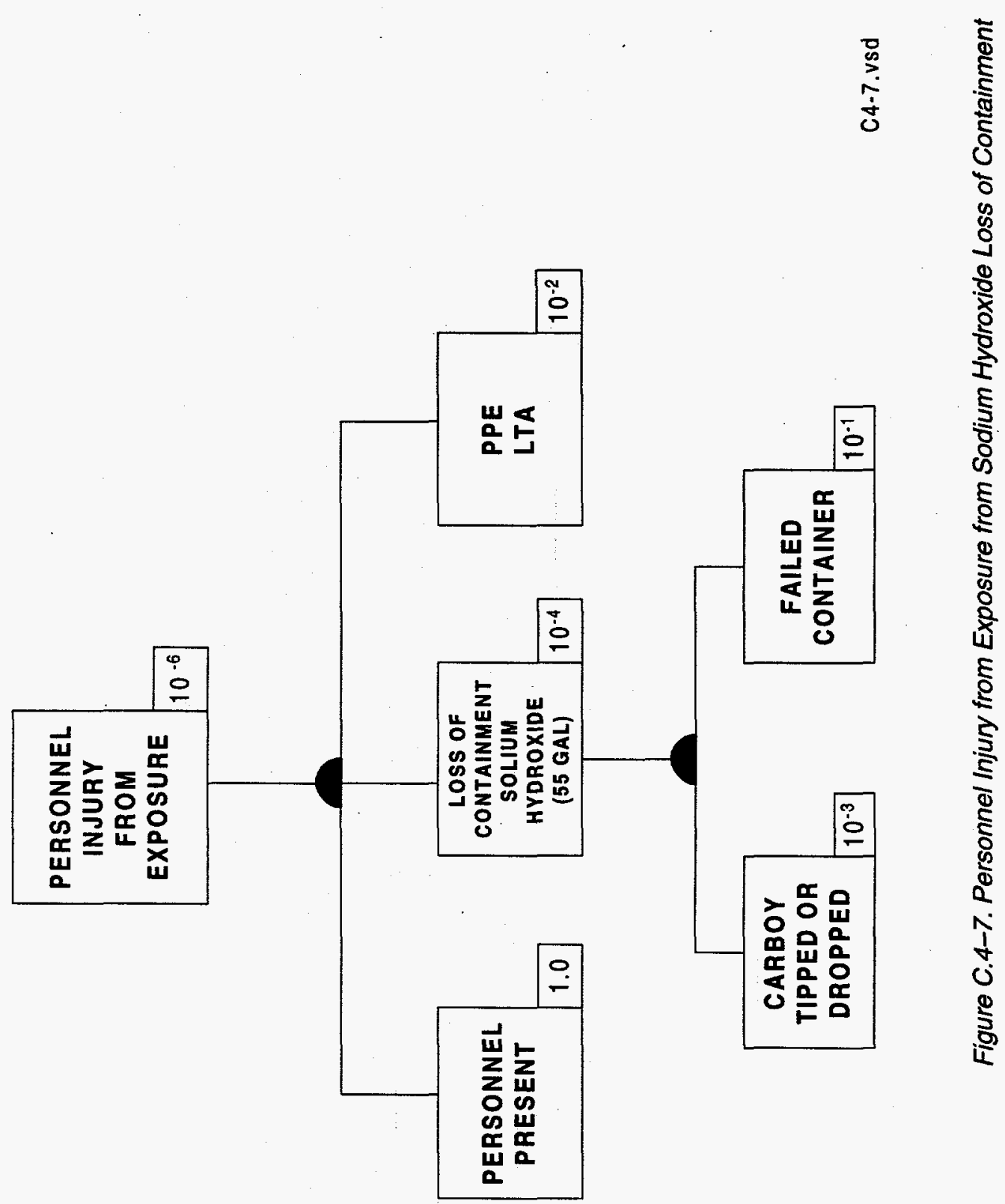




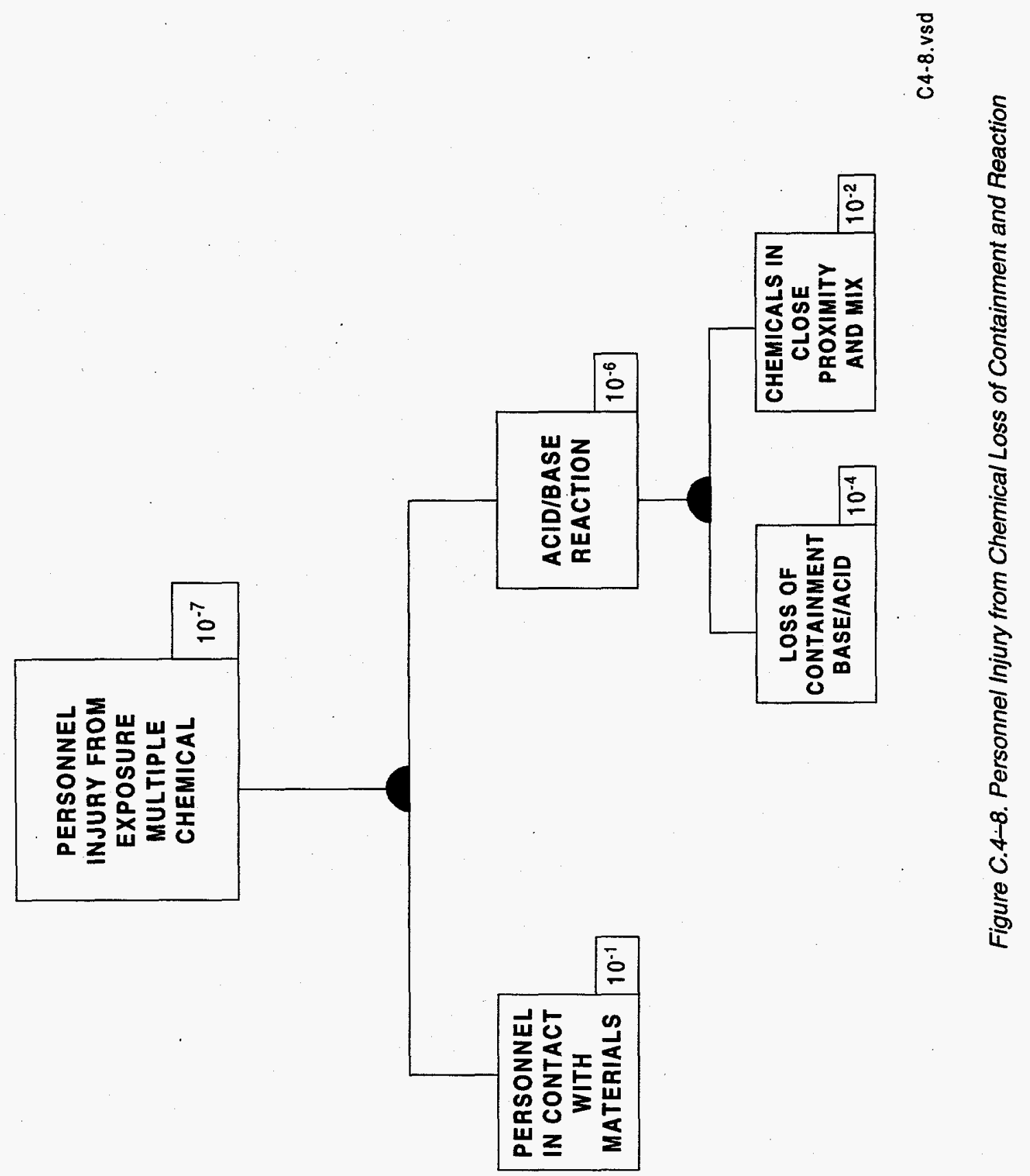




\section{C.5 Unmitigated Accident Consequences}

The results of the unmitigated accidents are discussed in this section. The computational methods, models, and assumptions are also presented. Input data for the calculations is provided for each model and computational method.

\section{C.5.1 Results By DBA}

The summary of the unmitigated accident consequences is provided in Table C.5.3-1. This table also provides a comparison to the evaluation criteria. Guidance for the Preparation of MWT Process Hazards Analysis (DOE 1995b) states to "compare the calculated exposure of the maximum exposed off-site individual against the evaluation guidelines presented in Appendix A (draft) to DOE-STD-3009 ..." However, Appendix A to DOE-STD-3009-94 was never published by DOE. Guidance was obtained from Vince Wahler of the DOE-AL Nuclear Safety Division regarding the evaluation criteria. DOE-AL indicated that the criteria of interest in the unpublished document was that equipment which mitigates a off-site dose at the site boundary to a member of the public in excess of 25 rem committed effective dose equivalent (CEDE) should be designated safety classification equipment. For chemicals, if the Emergency Response Planning Guidelines (ERPG) III level is not exceeded the site is a low hazard. For chemicals without ERPGs, a similar criterion may be used such as the facility is a low hazard if the immediately dangerous to life and health (IDLH) concentration is not exceeded. These criteria are for classifying equipment, and are not valid as risk acceptance guidelines.

Table C.5.3-1 shows the unmitigated accident consequences for each source term scenario of the fire/explosion DBA based on the evaluation basis site characteristic from Appendix A. As can be seen, the site boundary committed effective dose equivalent to a member of the public never exceeds the guideline value of $25 \mathrm{rem}$. The doses are several orders of magnitude below the guideline. The hazardous chemical concentrations at the site boundary are all less than the IDLH values, and are several orders of magnitude less than the guideline.

Additional consequences are given in Tables C.5.3-2 through C.5.3-4 for various distances from the PO*WW*ER MTU. These tables are provided for the sites where the nearest onsite worker and the offsite member of the public may differ in distance to those specified in Appendix A.

\section{C.5.2 Source-Term Analysis}

The materials at risk (MAR) described in Appendix B was used in the unmitigated accident analyses. To maximize the potential consequences of the analysis, the fire DBA assumes that the contents of the ethanol container are spilled, and an explosion/fire ensues. It was assumed that 50 percent of the ethanol was consumed in the fire, and 50 percent released to the atmosphere. The fire would likely consume the majority of the ethanol, thus releasing non-hazardous degradation products. The contents of the waste feed tank (i.e., $1,035 \mathrm{~kg}$ ) and the contents of the evaporator (i.e., $625 \mathrm{~kg}$ ) were assumed to be released during the event. The "worst case" MAR for the evaporator of $100 \mathrm{nCi} / \mathrm{g}$ was assumed to be concentrated by a factor of 10, while the "likely worst case" and "likely low activity/hazardous component" MARs were assumed to be concentrated by a factor of 100 at the time of the DBA.

One hundred percent of the radiological activity was assumed to be released in the fire with the respirable fraction of 0.05 percent taken from the HOTSPOT computer model (Homann 1994). The hazardous components of the source term (i.e., methylene chloride, isopropyl alcohol, and ammonia) were assumed to be fully released into the atmosphere and unaffected by the fire. This allowed for a conservative estimate of the airborne concentration of the hazardous materials. 
Table C.5.3-1. Unmitigated Consequences for the PO*WW*ER Unit Fire DBAs

\begin{tabular}{|c|c|c|c|c|c|}
\hline Fire DBA Event & Contaminant & $\begin{array}{c}\text { MTU } \\
\text { Worker }\end{array}$ & $\begin{array}{l}\text { On-Site } \\
\text { Nearest } \\
\text { Worker } \\
(0.3 \mathrm{~km})\end{array}$ & $\begin{array}{c}\text { Site Boundary } \\
(2.8 \mathrm{~km})\end{array}$ & Guideline $^{\mathrm{a}}$ \\
\hline \multirow[t]{6}{*}{ Worst Case } & plutonium & 109 rem & $\begin{array}{l}2.4 \times 10^{-3} \text { rem } \\
2.4 \mathrm{mrem}\end{array}$ & 0.046 mrem & $25 \mathrm{rem}$ \\
\hline & uranium & 26 rem & $8.7 \times 10^{-4}$ mrem & 0.015 mrem & 25 rem \\
\hline & ammonia & $>$ IDLH & $110 \mathrm{ppm}$ & $0.36 \mathrm{ppm}$ & 300 ppm IDLH \\
\hline & $\begin{array}{l}\text { isopropyl } \\
\text { alcohol }\end{array}$ & $>$ IDLH & $29 \mathrm{ppm}$ & $0.094 \mathrm{ppm}$ & 2,000 ppm IDLH \\
\hline & $\begin{array}{l}\text { methylene } \\
\text { chloride }\end{array}$ & $>$ IDLH & $5.5 \mathrm{ppm}$ & $0.018 \mathrm{ppm}$ & 2,300 ppm IDLH \\
\hline & ethyl alcohol & $>$ IDLH & $47 \mathrm{ppm}$ & 0.15 & 3,300 ppm IDLH \\
\hline \multirow{6}{*}{ Likely Worst Case } & plutonium & $3.6 \times 10^{-2} \mathrm{rem}$ & $7.0 \times 10^{-7} \mathrm{rem}$ & $1.3 \times 10^{-5} \mathrm{mrem}$ & $25 \mathrm{rem}$ \\
\hline & uranium & $1.4 \mathrm{rem}$ & $4.3 \times 10^{-5} \mathrm{rem}$ & $8.1 \times 10^{-4} \mathrm{mrem}$ & $25 \mathrm{rem}$ \\
\hline & ammonia & $>$ IDLH & $55 \mathrm{ppm}$ & $0.18 \mathrm{ppm}$ & 300 ppm IDLH \\
\hline & $\begin{array}{l}\text { isopropyl } \\
\text { alcohol }\end{array}$ & $>$ IDLH & 15 ppm & $0.051 \mathrm{ppm}$ & 2,000 ppm IDLH \\
\hline & $\begin{array}{l}\text { methylene } \\
\text { chloride }\end{array}$ & $>$ IDLH & $5.5 \mathrm{ppm}$ & $0.018 \mathrm{ppm}$ & 2,300 ppm IDLH \\
\hline & ethyl alcohol & $>$ IDLH & $47 \mathrm{ppm}$ & $0.15 \mathrm{ppm}$ & 3,300 ppm IDLH \\
\hline \multirow{6}{*}{$\begin{array}{l}\text { Likely Low-Activity, } \\
\text { Low-Hazardous } \\
\text { Concentration }\end{array}$} & plutonium & $2.6 \times 10^{-2} \mathrm{rem}$ & $1.4 \times 10^{-6} \mathrm{rem}$ & $2.7 \times 10^{-5}$ mrem & $25 \mathrm{rem}$ \\
\hline & uranium & 0.73 rem & $2.1 \times 10^{-5} \mathrm{rem}$ & $4.0 \times 10^{-4} \mathrm{mrem}$ & $25 \mathrm{rem}$ \\
\hline & ammonia & $>$ IDLH & $31 \mathrm{ppm}$ & $0.10 \mathrm{ppm}$ & 300 ppm IDLH \\
\hline & $\begin{array}{l}\text { isopropyl } \\
\text { alcohol }\end{array}$ & $>$ IDLH & 15 ppm & $0.051 \mathrm{ppm}$ & 200 ppm IDLH \\
\hline & $\begin{array}{l}\text { methylene } \\
\text { chloride }\end{array}$ & $>$ IDLH & $5.5 \mathrm{ppm}$ & $0.018 \mathrm{ppm}$ & 2,300 ppm IDLH \\
\hline & ethyl alcohol & $>\mathrm{IDLH}$ & $47 \mathrm{ppm}$ & 0.15 ppm & 3,300 ppm IDLH \\
\hline
\end{tabular}

${ }^{a}$ Guidance for the Preparation of MWT Process Hazards Analysis references Appendix A of DOE-STD-3009-94, which was never published. Vince Wahler of DOE-AL Nuclear Safety Division indicated that the criteria of interest in the unpublished document was that equipment that mitigates a site boundary dose to a member of the public in excess of 25 rem committed effective dose equivalent should be designated safety classification equipment. For chemicals, if the Emergency Response Planning Guideline (ERPG) Level III is not exceed the site is a low hazard. For chemicals without ERPGs, a similar criteria may be used such as a facility is low hazard if the IDLH concentration is not exceeded at the site boundary.

Key: $\mathrm{DBA}=$ design basis accident

IDLH = immediately dangerous to life or health

$\mathrm{km}=$ kilometer(s)

mrem $=$ milliroentgen $(s)$

MTU = mobile treatment unit

$\mathrm{ppm}=$ parts per million

rem $=$ roentgen $(s)$ 
Table C.5.3-2. Unmitigated Accident Consequences for "Worst Case" Source-Term Scenario

\begin{tabular}{||c|l|l|l|l|l|l||}
\hline $\begin{array}{c}\text { Listance } \\
(\mathrm{km}) \text { from } \\
\text { MTU }\end{array}$ & $\begin{array}{c}\text { Plutonium } \\
(\mathrm{mrem})\end{array}$ & $\begin{array}{c}\text { Uranium } \\
(\mathrm{mrem})\end{array}$ & $\begin{array}{c}\text { Ammonia } \\
(\mathrm{ppm})\end{array}$ & $\begin{array}{c}\text { Isopropyl } \\
\text { Alcohol } \\
(\mathrm{ppm})\end{array}$ & $\begin{array}{c}\text { Methylene } \\
\text { Chloride } \\
(\mathbf{p p m})\end{array}$ & $\begin{array}{c}\text { Ethyl } \\
\text { Alcohol } \\
\text { (ppm) }\end{array}$ \\
\hline 0.1 & 7.6 & 2.8 & 7.6 & 2.0 & 0.39 & 3.3 \\
\hline 0.2 & 4.2 & 1.5 & 110 & 30 & 5.8 & 49 \\
\hline 0.5 & 2.4 & 0.87 & 58 & 15 & 3.0 & 22 \\
\hline 1.0 & 0.31 & 0.11 & 13 & 3.5 & 0.67 & 5.7 \\
\hline 2.0 & 0.085 & 0.031 & 1.1 & 0.29 & 0.055 & 0.47 \\
\hline 5.0 & 0.016 & 0.0057 & 0.048 & 0.013 & 0.0024 & 0.20 \\
\hline 10.0 & 0.0046 & 0.0017 & 0.0035 & $9.3 \times 10^{-4}$ & $1.8 \times 10^{-4}$ & 0.0015 \\
\hline 20.0 & 0.0014 & 0.0005 & $4.9 \times 10^{-4}$ & $1.3 \times 10^{-4}$ & $2.5 \times 10^{-5}$ & $2.1 \times 10^{-4}$ \\
\hline
\end{tabular}

Key: $\mathrm{km}=$ kilometer(s)

ppm = parts per million

mrem $=$ milliroentgen(s)

MTU = mobile treatment unit

Table C.5.3-3. Unmitigated Accident Consequences for "Likely Worst Case" Source-Term Scenario

\begin{tabular}{||c|c|c|c|c|c|c|}
\hline $\begin{array}{c}\text { Distance } \\
(\mathrm{km}) \text { from } \\
\text { MTU }\end{array}$ & $\begin{array}{c}\text { Plutonium } \\
(\mathbf{m r e m})\end{array}$ & $\begin{array}{c}\text { Uranium } \\
(\mathrm{mrem})\end{array}$ & $\begin{array}{c}\text { Ammonia } \\
(\mathrm{ppm})\end{array}$ & $\begin{array}{c}\text { Isopropyl } \\
\text { Alcohol } \\
(\mathrm{ppm})\end{array}$ & $\begin{array}{c}\text { Methylene } \\
\text { Chloride } \\
(\mathbf{p p m})\end{array}$ & $\begin{array}{c}\text { Ethyl } \\
\text { Alcohol } \\
\text { (ppm) }\end{array}$ \\
\hline 0.1 & 0.0022 & 0.13 & 3.8 & 1.1 & 0.39 & 3.3 \\
\hline 0.2 & 0.0012 & 0.074 & 57 & 16 & 5.8 & 49 \\
\hline 0.5 & $7.0 \times 10^{-4}$ & 0.019 & 29 & 8.3 & 3.0 & 25 \\
\hline 1.0 & $9.0 \times 10^{-5}$ & 0.0055 & 6.7 & 1.9 & 0.67 & 5.7 \\
\hline 2.0 & $2.5 \times 10^{-5}$ & 0.0015 & 0.55 & 0.15 & 0.055 & 0.47 \\
\hline 5.0 & $4.6 \times 10^{-6}$ & $2.8 \times 10^{-4}$ & 0.024 & 0.0067 & 0.0024 & 0.021 \\
\hline 10.0 & $1.3 \times 10^{-6}$ & $8.2 \times 10^{-5}$ & 0.0018 & $5.0 \times 10^{-4}$ & $1.8 \times 10^{-4}$ & .00015 \\
\hline 20.0 & $4.1 \times 10^{-7}$ & $2.5 \times 10^{-5}$ & $2.5 \times 10^{-4}$ & $7.0 \times 10^{-5}$ & $2.5 \times 10^{-5}$ & $2.1 \times 10^{-4}$ \\
\hline
\end{tabular}

Key: $\mathrm{km}=$ kilometer(s)

ppm = parts per million

mrem = milliroentgen(s)

MTU = mobile treatment unit 
Table C.5.3-4. Unmitigated Accident Consequences for "Likely Low-Hazard Case" Source-Term Scenario

\begin{tabular}{|c|c|c|c|c|c|c||}
\hline $\begin{array}{c}\text { Distance } \\
(\mathbf{k m}) \text { from } \\
\text { MTU }\end{array}$ & $\begin{array}{c}\text { Plutonium } \\
(\mathrm{mrem})\end{array}$ & $\begin{array}{c}\text { Uranium } \\
(\mathrm{mrem})\end{array}$ & $\begin{array}{c}\text { Ammonia } \\
(\mathrm{ppm})\end{array}$ & $\begin{array}{c}\text { Isopropyl } \\
\text { Alcohol } \\
(\mathrm{ppm})\end{array}$ & $\begin{array}{c}\text { Methylene } \\
\text { Chloride } \\
(\mathrm{ppm})\end{array}$ & $\begin{array}{c}\text { Ethyl } \\
\text { Alcohol } \\
(\mathrm{ppm})\end{array}$ \\
\hline 0.1 & 0.0045 & 0.067 & 2.1 & 1.1 & 0.39 & 3.3 \\
\hline 0.2 & 0.0025 & 0.037 & 32 & 16 & 5.8 & 49 \\
\hline 0.5 & 0.00063 & 0.0093 & 16 & 8.3 & 3.0 & 25 \\
\hline 1.0 & 0.00018 & 0.0027 & 3.7 & 1.9 & 0.67 & 5.7 \\
\hline 2.0 & $5.1 \times 10^{-5}$ & 0.00075 & 0.31 & 0.15 & 0.055 & 0.47 \\
\hline 5.0 & $9.4 \times 10^{-6}$ & 0.00014 & 0.013 & 0.0067 & 0.0024 & 0.021 \\
\hline 10.0 & $2.7 \times 10^{-6}$ & $4.0 \times 10^{-5}$ & $9.9 \times 10^{-4}$ & $5.0 \times 10^{-4}$ & $1.8 \times 10^{-4}$ & 0.0015 \\
\hline 20.0 & $8.4 \times 10^{-7}$ & $1.2 \times 10^{-5}$ & $1.4 \times 10^{-4}$ & $7.0 \times 10^{-5}$ & $2.5 \times 10^{-5}$ & $2.1 \times 10^{-4}$ \\
\hline
\end{tabular}

Key: $\mathrm{km}=$ kilometer(s)

$\mathrm{ppm}=$ parts per million

mrem $=$ milliroentgen(s)

MTU = mobile treatment unit

The respirable fraction of each component of the source term was assumed to be released into the room for the worker exposure. In addition, the respirable fraction was also assumed to be available to the onsite worker and the public. This allowed for a conservative, generic analysis which avoids the uncertainty of leak-path factors for releases from the facility.

\section{C.5.3 Description of Calculational Methods}

Three calculation methods were used in the assessment of onsite and off-site radiological doses and chemical concentrations. The worker located in the building housing the PO*WW*ER MTU was assessed using simple hand calculation methods. The nearest onsite worker and off-site member of the public were assessed using the computer models EPIcode (Homann 1988) and HOTSPOT (Homann 1994).

\section{PO*WW*ER Unit Worker Model}

This assessment consisted of simplified calculations for the determination of the contaminant concentrations in the air of the room housing the PO*WW*ER MTU. The material at risk was adjusted for each DBA according to the fraction that was considered respirable. To be consistent with the HOTSPOT computer code used for offsite analyses, the respirable fraction for plutonium and uranium of 0.05 percent was assumed for the fire DBA. The ethanol, which created the fire, was assumed to be 50 percent consumed by the fire with the other 50 percent being released into the room.

The respirable fraction was assumed to be released instantaneously into a room assumed to be the equivalent to that required to house the PO*WW*ER MTU footprint (i.e., $880 \mathrm{~m}^{3}$ ). The worker then was assumed to reside in the room for 30 minutes, considered a reasonable time for rescue of the worker by onsite personnel. 
The following equation was used to calculate the CEDE from inhalation of radionuclides by the worker:

$$
D=C_{a} * B_{r} * E_{t} * D C F
$$

where: $D=$ committed effective dose equivalent (rem)

$C_{a}=$ radionuclide air concentration $\left(\mu \mathrm{Ci} / \mathrm{m}^{3}\right)$

$B_{r}=$ worker breathing rate $\left(\mathrm{m}^{3} / \mathrm{h}\right)$

$E_{t} \quad=$ exposure time (h)

$D C F=$ dose conversion factor for inhalation $(\mathrm{rem} / \mu \mathrm{Ci})$

The concentration of the hazardous chemicals in the atmosphere of the room were determined as follows:

$$
C_{h}=\frac{S_{h}}{A_{r} \rho_{a}}
$$

where: $\quad C_{h}=$ air concentration of hazardous component (ppm)

$S_{h}=$ source term of hazardous component (mg)

$A_{r}=$ volume of the room $\left(\mathrm{m}^{3}\right)$

$\rho_{\mathrm{a}}=$ density of air $\left(\mathrm{kg} / \mathrm{m}^{3}\right)$

The input assumption for the $\mathrm{PO} * \mathrm{WW} * \mathrm{ER}$ worker parameters are given in Table C.5.3-5.

\section{On-Site Worker and Off-Site Public Radiological Dispersion Model}

The HOTSPOT computer code (Homann 1994) was used for the calculation of radiological doses for the nearest on-site worker and the off-site public. HOTSPOT uses the well-established Gaussian plume model, widely used for safety-analysis planning of a radionuclide release. The dosimetric methods of the International Commission on Radiological Protection (ICRP) Publication 30 are used in the HOTSPOT program. The HOTSPOT dose values are due solely to the inhalation of released material during passage of the plume. The ground-shine dose is not included because the committed effective dose equivalent (per hour of time in the contaminated area) due to ground shine is typically several orders of magnitude less than the committed effective dose equivalent due to plume passage. For alpha-emitting radionuclides (i.e., plutonium and uranium) the hourly ground-shine component is at least 7 orders of magnitude less than the inhalation component.

The Gaussian model has been used and accepted by the Environmental Protection Agency. The adequacy of the this model for making initial dispersion estimates or worst-case safety analyses has been tested and verified for many years.

HOTSPOT requires the input of the release height. The fire/explosion DBA would generate heat thus creating a buoyant plume rise in the ambient air. The determination of the plume rise was determined using HOTSPOT using a heat of combustion value of $6620 \mathrm{cal} / \mathrm{g}$ for ethanol, and assuming that the liquid pooled to a $1 \mathrm{~cm}$ depth on the floor. This resulted in a released radius of $1.82 \mathrm{~m}$ and a burn duration of 2 to 10 minutes. For purposes of conservatism, the burn duration was chosen as 2 minutes to completely consume 50 percent of the ethanol. These assumptions resulted in a HOTSPOT calculated plume rise of 69 meters. For purposes of conservatism, half of this value was assumed (i.e., 35 meters). The meteorological parameters were also maximized as stability category $A$ and a 1-meter-per-second $(\mathrm{m} / \mathrm{s})$ wind speed assumed to be in the direction of the off-site public during the duration of the event. A stability 
category $\mathrm{A}$ is unstable and creates the condition where the elevated plume is brought to the ground. The input parameter values used in HOTSPOT are given in Table C.5.3-5.

\section{On-Site Worker and Off-Site Public Hazardous Air Concentration Model}

EPIcode (Homann 1988) was used for the calculation of the hazardous air concentrations for the nearest on-site worker and the off-site public. EPIcode uses the well-established Gaussian plume model, which is widely used for safety analysis planning of a chemical release. The EPIcode library contains information on over 600 toxic substances listed in the Threshold Limit Values and Biological Exposure Indices published by the American Governmental Conference of Governmental Industrial Hygienist.

For the fire/explosion DBA, EPIcode requires the estimation of the duration of the event, and the radius of the release. The values determined using HOTSPOT for the plume rise were used with a 2-minute release duration and a 1.82-meter radius of release. The larger the values for duration and radius of release the lower the predicted doses.

EPIcode requires the input of the release height. Once again, the release height determined by HOTSPOT was used assuming half of the calculated value for conservatism. The meteorological parameters were also maximized as stability category $A$ and $\cdot 1-\mathrm{m} / \mathrm{s}$ wind speed assumed to be in the direction of the offsite public during the duration of the event.

The input parameter values used in EPIcode are given in Table C.5.3-5. 
Table C.5.3-5. Input Parameter Values Used in The Unmitigated Accident Analyses

\begin{tabular}{|c|c|c|c|c|c|c|}
\hline \multicolumn{3}{|c|}{ Parameter } & Value & \multicolumn{2}{|l|}{ Application } & Comments \\
\hline \multicolumn{3}{|c|}{ Area of the room } & $880 \mathrm{~m}^{3}$ & \multicolumn{2}{|l|}{ MTU worker } & MTU footprint \\
\hline \multicolumn{3}{|c|}{ Worker breathing rate } & $1.2 \mathrm{~m}^{3} / \mathrm{h}$ & \multicolumn{2}{|l|}{ All Scenarios } & $\begin{array}{l}\text { HOTSPOT/EPIcode } \\
\text { value }\end{array}$ \\
\hline \multicolumn{3}{|c|}{ Exposure time worker } & $0.5 \mathrm{~h}$ & \multicolumn{2}{|l|}{ MTU worker } & assumed rescue time \\
\hline \multicolumn{3}{|c|}{ Exposure time offsite } & $\begin{array}{l}\text { plume passage } \\
\text { duration }\end{array}$ & \multicolumn{2}{|l|}{ all except MTU worker } & determined by codes \\
\hline \multicolumn{3}{|c|}{ Air density } & $1.2 \mathrm{~kg} / \mathrm{m}^{3}$ & \multicolumn{2}{|l|}{ MTU worker } & \\
\hline \multicolumn{3}{|c|}{ Release radius } & $1.82 \mathrm{~m}$ & \multicolumn{2}{|l|}{ All except MTU worker } & conservative value \\
\hline \multicolumn{3}{|c|}{ Release height } & $35 \mathrm{~m}$ & \multicolumn{2}{|l|}{$\begin{array}{l}\text { All except MTU worker } \\
\text { (determined using HOTSPOT) }\end{array}$} & conservative value \\
\hline \multicolumn{3}{|c|}{ Release duration } & 2 minutes & \multicolumn{2}{|l|}{$\begin{array}{l}\text { All except MTU worker } \\
\text { (determined using HOTSPOT) }\end{array}$} & conservative value \\
\hline \multicolumn{3}{|c|}{ Stability Class } & A & \multicolumn{2}{|l|}{ All except MTU worker } & conservative value \\
\hline \multicolumn{3}{|c|}{ Wind speed } & $1 \mathrm{~m} / \mathrm{s}$ & \multicolumn{2}{|l|}{ All except MTU worker } & conservative value \\
\hline \multicolumn{3}{|c|}{ Receptor location } & plume centerline & All except MTU worker & & conservative value \\
\hline $\mathrm{Sp}$ & fic Acti & vity Pu & $8.1 \times 10^{-2} \mathrm{Ci} / \mathrm{g}$ & All Scenarios & & $\begin{array}{l}\text { weapons-grade } \\
\text { plutonium }\end{array}$ \\
\hline Sp & fic Acti & vity U & $1.55 \times 10^{-6} \mathrm{Ci} / \mathrm{g}$ & All Scenarios & & enriched uranium \\
\hline Pu & tivity & & $\begin{array}{l}100 \mathrm{nCi} / \mathrm{g} \\
3.3 \times 10^{-6} \mu \mathrm{Ci} / \mathrm{g} \\
2.4 \times 10^{-6} \mu \mathrm{Ci} / \mathrm{g}\end{array}$ & $\begin{array}{l}\text { Worst Case } \\
\text { Likely Worst Case } \\
\text { Likely Low Activity Case }\end{array}$ & & $\begin{array}{l}8.99 \times 10^{-3} \mathrm{~kg} \\
2.62 \times 10^{-6} \mathrm{~kg} \\
1.86 \times 10^{-6} \mathrm{~kg}\end{array}$ \\
\hline$\cup A$ & ivity & & $\begin{array}{l}100 \mathrm{nCi} / \mathrm{g} \\
5.6 \times 10^{-4} \mu \mathrm{Ci} / \mathrm{g} \\
2.8 \times 10^{-4} \mu \mathrm{Ci} / \mathrm{g}\end{array}$ & $\begin{array}{l}\text { Worst Case } \\
\text { Likely Worst Case } \\
\text { Likely Low Activity Case }\end{array}$ & & $\begin{array}{l}470 \mathrm{~kg} \\
23 \mathrm{~kg} \\
11.4 \mathrm{~kg}\end{array}$ \\
\hline Eth & & & $164 \mathrm{~kg}$ & $\begin{array}{l}\text { All Cases (50\% burned, } 50 \% \\
\text { release) }\end{array}$ & & $\begin{array}{l}27.4 \text { gal burned } \\
27.4 \text { gal release }\end{array}$ \\
\hline Me & lene ct & hloride & $\begin{array}{l}1.3 \text { weight } \% \\
1.3 \text { weight } \% \\
0.88 \text { weight } \%\end{array}$ & $\begin{array}{l}\text { Worst Case } \\
\text { Likely Worst Case } \\
\text { Likely Low Activity Case }\end{array}$ & & $\begin{array}{l}3.55 \mathrm{gal} \\
3.55 \mathrm{gal} \\
2.4 \mathrm{gal}\end{array}$ \\
\hline Iso & spyl Alc & cohol & $\begin{array}{l}8 \text { weight } \% \\
4.3 \text { weight } \% \\
4 \text { weight } \%\end{array}$ & $\begin{array}{l}\text { Worst Case } \\
\text { Likely Worst Case } \\
\text { Likely Low Activity Case }\end{array}$ & & $\begin{array}{l}21.9 \mathrm{gal} \\
11.8 \mathrm{gal} \\
10.9 \mathrm{gal}\end{array}$ \\
\hline Am & onia & & $\begin{array}{l}10 \text { weight } \% \\
5 \text { weight } \% \\
2.8 \text { weight } \%\end{array}$ & $\begin{array}{l}\text { Worst Case } \\
\text { Likely Worst Case } \\
\text { Likely Low Activity Case }\end{array}$ & & $\begin{array}{l}27.3 \mathrm{gal} \\
13.7 \mathrm{gal} \\
7.66 \mathrm{gal}\end{array}$ \\
\hline MA & & & $\begin{array}{l}1,035 \mathrm{~kg} \\
625 \mathrm{~kg}\end{array}$ & $\begin{array}{l}\text { Waste Feed Tank } \\
\text { Evaporator }\end{array}$ & & See Appendix B \\
\hline Key: & $\begin{array}{l}\mathrm{Ci} / \mathrm{g} \\
\mathrm{gal} \\
\mathrm{h} \\
\mathrm{kg} \\
\mathrm{kg} / \mathrm{m}^{3}\end{array}$ & $\begin{array}{l}=\text { curies } \\
=\text { gallon } \\
=\text { hour }(s \\
=\text { kilogre } \\
=\text { kilogra }\end{array}$ & $\begin{array}{l}\mathrm{km} \\
\mathrm{m} \\
\mathrm{m}^{3} \\
\mathrm{~m}^{3} / \mathrm{h} \\
\mathrm{m} / \mathrm{s}\end{array}$ & $\begin{array}{l}=\text { kilometer(s) } \\
=\text { meter(s) } \\
=\text { cubic meter(s) } \\
=\text { cubic meter(s) per hour } \\
=\text { meter(s) per second }\end{array}$ & $\begin{array}{l}\text { nCi/g } \\
\text { ppm } \\
\text { Pu } \\
U\end{array}$ & $\begin{array}{l}=\text { nanocuries per gram } \\
=\text { parts per million } \\
=\text { Plutonium } \\
=\text { Uranium }\end{array}$ \\
\hline
\end{tabular}




\section{Attachment C.5.3-1}

Table C.5.3-1. Dose Rate Calculation 
This page intentionally blank 


\section{Attachment C.5.3-1. Dose Rate Calculation}

To understand the dose conditions that would exist if fission or activation products were introduced into the process vessels, the dose rate was calculated from a 55-gallon drum containing an evaporator concentrate brine solution that includes cobalt- 60 , a high-energy gamma-emitting radionuclide.

In addition to the 55-gallon drum, the evaporator tank will also contain the brine solution. The conical tank shape makes quantitative dose rate modeling. The program does not explicitly handle this shape so some approximations are necessary and the analysis is done only for the drum. It is likely that the self-shielding from a larger volume of brine will counteract the higher activity in the larger evaporator tank volume and the dose rate from the drum and evaporator are likely to similar.

The following assumptions are made:

The 55-gallon drum is 34 inches tall and 23 inches in diameter with a 1/8-inch thick iron wall. The dose points of interest are $10 \mathrm{~cm}$ and $100 \mathrm{~cm}$ from the surface of the drum. The brine is a high density aqueous solution with a specific gravity of $1.5 \mathrm{~g} / \mathrm{cm}^{3}$. It was concentrated by a factor of 100 from aqueous feed material containing $100 \mathrm{pCi} / \mathrm{g}$ of cobalt- 60 . The resulting activity concentration in the brine is $10 \mathrm{nCi} / \mathrm{cm}^{3}$. Cobalt -60 represents a worst likely case radionuclide for both fission and activation products and therefore adds conservatism to this analysis.

The program Microshield 4.0 (Grove Engineering) was used to calculate the dose rates. Figure C.5.3-1 includes the report of the calculations. Table 1 shows the calculated dose rates for the two distances.

Table C.5.3-1. Dose Rate from a 55-gallon Drum Containing Cobalt-60 at $10 \mathrm{nCi} / \mathrm{cm}^{3}$

\begin{tabular}{|c|c|}
\hline Distance from drum surface, cm & Dose Rate, mrem/r \\
\hline 10 & 2.7 \\
\hline 100 & 0.61 \\
\hline
\end{tabular}

This screening analysis shows that the dose rate from the drum at one meter distance is half the level that requires posting as a radiation area $(5 \mathrm{mrem} / \mathrm{hour})$ if the activity in the feed material is constrained to $100 \mathrm{pCi} / \mathrm{g}$ and the concentration ratio in the evaporator is 100 or less. Considering the conservative assumptions regarding the concentration ratio and radionuclides, the dose rate in occupied areas will be acceptable even if all of the activity in the feed material is associated with fission or activation products. 
Figure C.5.3-1. Report on Dose Rate Calculation

Microshield 4.00 - Serial \#4.00-00099

Page 1

DOS File: POWBRIN2.MS4

Run Date: May 16, 1996

Run Time: $3: 37$ p.m. Thursday

Duration: 0:00:06

Geotech

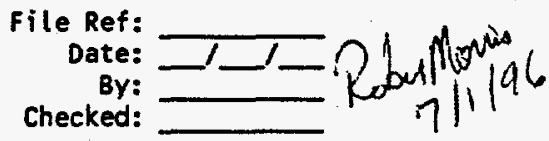

Case Title: POWWR brine in 55 gallon drum Co-60 at $10 \mathrm{~cm}$

GEOMETRY 7 - Cylinder Volume - side shields

centimeters feet and inches

$\begin{array}{lrrr}\text { Dose point coordinate } X: & 39.0 & 1.0 & 3.4 \\ \text { Dose point coordinate } Y: & 100.0 & 3.0 & 3.4 \\ & & \end{array}$

Dose point coordinate $Z$

Cylinder height:

Cylinder radius:

Shield 1:

86.36

29.0

2.0

10.0

0.3175

$0.0 \quad 11.4$

Air Gap:

9.6825

0.0

.1

$0.0 \quad 3.8$

Source Volume: $228170 . \mathrm{cm}^{* 3} \quad 8.05775 \mathrm{cu} f t .13923 .8 \mathrm{cu}$ in.

$\begin{array}{lccccc}\text { Material } & \begin{array}{c}\text { MATERIAL DENSITIES }\left(\mathrm{g} / \mathrm{cm}^{-3} 3\right) \\ \text { Source } \\ \text { Shield }\end{array} & \begin{array}{l}\text { Shield 1 } \\ \text { Cylinder }\end{array} & \begin{array}{l}\text { Transition } \\ \text { Shield }\end{array} & \text { Air Gap } & \begin{array}{c}\text { Immersion } \\ \text { Shield }\end{array} \\ \begin{array}{l}\text { Air } \\ \text { Iron }\end{array} & & 7.86 & 0.00122 & 0.00122 & 0.00122 \\ \text { Hater } & 1.5 & 7.86 & & & \end{array}$

BUILDUP

Method: Buildup Factor Tables

The material reference is Source

\section{INTEGRATION PARAMETERS}

Quadrature Order

Radial

10

Circumferential.

Axial (along $Z$ )

10
10

SOURCE NUCLIDES

Co-60 2.2817e-003 1.0000 -

\begin{tabular}{|c|c|c|c|c|c|}
\hline $\begin{array}{l}\text { Energy } \\
\text { (MeV) }\end{array}$ & $\begin{array}{c}\text { Activity } \\
\text { (photons/sec) }\end{array}$ & $\begin{array}{r}\text { Energy F } \\
(\mathrm{MeV} / \mathrm{s}\end{array}$ & $\begin{array}{l}\text { uence Rate } \\
(\mathrm{m} / \mathrm{sec} \text { ) }\end{array}$ & $\begin{array}{r}\text { Exposure } R a \\
(\mathrm{mR} / \mathrm{h}\end{array}$ & $\begin{array}{l}\text { te In Air } \\
\text { r) }\end{array}$ \\
\hline $\begin{array}{l}0.6 \\
1.0 \\
1.5\end{array}$ & $\begin{array}{l}1.377 e+004 \\
8.442 e+007 \\
8.442 e+007\end{array}$ & $\begin{array}{l}\text { No Buildup } \\
1.698 \mathrm{e}-002 \\
2.337 \mathrm{e}+002 \\
4.444 \mathrm{e}+002\end{array}$ & $\begin{array}{c}\text { With Buildup } \\
5.496 \mathrm{e}-002 \\
5.849 \mathrm{e}+002 \\
9.397 \mathrm{e}+002\end{array}$ & $\begin{array}{l}\text { No Buildup } \\
3.314 \mathrm{e}-005 \\
4.307 \mathrm{e}-001 \\
7.476 \mathrm{e}-001\end{array}$ & $\begin{array}{l}\text { With Buildup } \\
1.073 \mathrm{e}-004 \\
1.078 \mathrm{e}+000 \\
1.581 \mathrm{e}+000\end{array}$ \\
\hline TOTAL: & $1.689 \mathrm{e}+008$ & $\overline{6.781 e+002}$ & $\overline{1.525 e+003}$ & $1.178 \mathrm{e}+000$ & $\overline{2.659 \mathrm{e}+000}$ \\
\hline
\end{tabular}


Microshield 4.00 - Serial \#4.00-00099

Geotech

Page : 1

DOS File: POWBRIN4.MS4

Run Date: May 17, 1996

Run Time: 2:08 p.m. Friday

Duration: 0:00:06
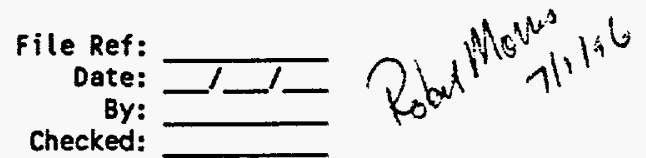

Case Title: POWWR brine in $55 \mathrm{gal}$ drum, Co-60, $0.1 \mathrm{uci} / \mathrm{cc}$ at $100 \mathrm{~cm}$

GEOMETRY 7 - Cylinder Volume - side Shields.

centimeters feet and inches

$\begin{array}{llll}\text { Dose point coordinate } X: & 129.0 & 4.0 & 2.8 \\ \text { Dose point coordinate } Y: & 100.0 & 3.0 & 3.4\end{array}$

Dose point coordinate Z: $\quad 0.0 \quad 0.0 \quad 0$

Cylinder height: $\quad 86.36 \quad 2.0 \quad 10.0$

Cylinder radius: $\quad 29.0 \quad 0.0 \quad 11.4$

$\begin{array}{rrrr}\text { Shield 1: } & 0.3175 & 0.0 & .1 \\ \text { Air Gap: } & 99.6825 & 3.0 & 3.2\end{array}$

Source Volume: $228170 . \mathrm{cm}^{-3} \quad 8.05775 \mathrm{cu} f t .13923 .8 \mathrm{cu}$ in.

\begin{tabular}{|c|c|c|c|c|c|}
\hline \multirow[b]{2}{*}{ Material } & \multicolumn{5}{|c|}{ MATERIAL DENSITIES $\left(\mathrm{g} / \mathrm{cm}^{\wedge} 3\right)$} \\
\hline & $\begin{array}{l}\text { Source } \\
\text { Shield }\end{array}$ & $\begin{array}{l}\text { Shield } 1 \\
\text { Cyl inder }\end{array}$ & $\begin{array}{l}\text { Transition } \\
\text { shield }\end{array}$ & Air Gap & $\begin{array}{l}\text { Imnersion } \\
\text { Shield }\end{array}$ \\
\hline $\begin{array}{l}\text { Air } \\
\text { Iron } \\
\text { Water }\end{array}$ & 1.5 & 7.86 & 0.00122 & 0.00122 & 0.00122 \\
\hline
\end{tabular}

BUILDUP

Method: Buildup Factor Tables

The material reference is Source

INTEGRATION PARAMETERS

Quadrature Order

Radial

Circumferential

Axial (along $Z$ )

10

10

10

$\begin{array}{lcc}\text { Nucl ide } & \text { curies } & \mu \mathrm{Ci} / \mathrm{cm}^{3} 3 \\ \text { Co-60 } & 2.2809 \mathrm{e}-003 & 9.9964 \mathrm{e}-003\end{array}$

\begin{tabular}{|c|c|c|c|c|c|}
\hline \multicolumn{6}{|c|}{ 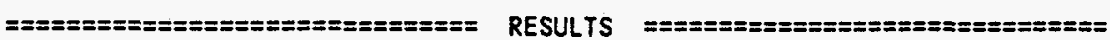 } \\
\hline $\begin{array}{l}\text { Energy } \\
\text { (MeV) }\end{array}$ & $\begin{array}{c}\text { Activity } \\
\text { (photons/sec) }\end{array}$ & $\begin{array}{r}\text { Energy } F \\
(\mathrm{MeV} / \mathrm{s} C\end{array}$ & $\begin{array}{l}\text { uence Rate } \\
(\mathrm{cm} / \mathrm{sec} \text { ) }\end{array}$ & $\begin{array}{r}\text { Exposure } R a \\
(m R / h\end{array}$ & te In Air \\
\hline $\begin{array}{l}0.6 \\
1.0 \\
1.5\end{array}$ & $\begin{array}{l}1.377 e+004 \\
8.439 e+007 \\
8.439 e+007\end{array}$ & $\begin{array}{l}\text { No Buildup } \\
4.090 \mathrm{e}-003 \\
5.554 \mathrm{e}+001 \\
1.045 \mathrm{e}+002\end{array}$ & $\begin{array}{c}\text { with Buildup } \\
1.273 e-002 \\
1.345 e+002 \\
2.145 e+002\end{array}$ & $\begin{array}{l}\text { No Buildup } \\
7.984 \mathrm{e}-006 \\
1.024 \mathrm{e}-001 \\
1.758 \mathrm{e}-001\end{array}$ & $\begin{array}{l}\text { With Buildup } \\
2.485 e-005 \\
2.480 e-001 \\
3.609 e-001\end{array}$ \\
\hline TOTAL: & $\overline{1.688 e+008}$ & $\overline{1.601 \mathrm{e}+002}$ & $\overline{3.491 \mathrm{e}+002}$ & $\overline{2.782 e-001}$ & $6.089 e-001$ \\
\hline
\end{tabular}


This page intentionally blank 